Prepared in cooperation with the

Massachusetts Department of Environmental Protection

\title{
Hydraulic Assessment of Existing and Alternative Stream Crossings Providing Fish and Wildlife Passage at Seven Sites in Massachusetts
}

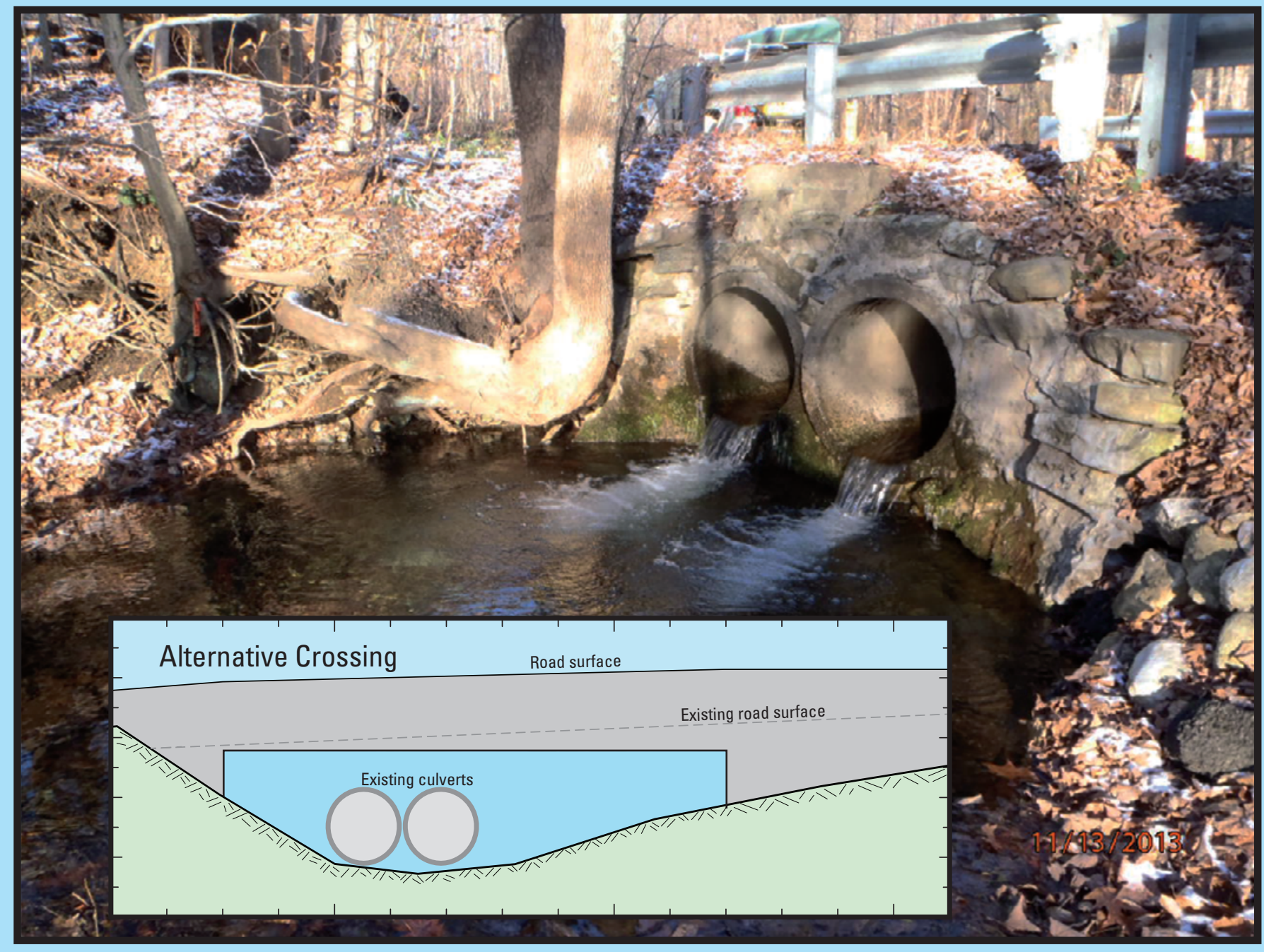

Scientific Investigations Report 2014-5146 
Cover. Photograph of downstream face of Churchill Brook crossing in Pittsfield, Massachusetts, at Hancock Road. Inset shows alternate road crossing. Photograph by U.S. Geological Survey field worker. 


\section{Hydraulic Assessment of Existing and Alternative Stream Crossings Providing Fish and Wildlife Passage at Seven Sites in Massachusetts}

By Phillip J. Zarriello and Jeffrey R. Barbaro

Prepared in cooperation with the

Massachusetts Department of Environmental Protection

Scientific Investigations Report 2014-5146 


\title{
U.S. Department of the Interior SALLY JEWELL, Secretary
}

\section{U.S. Geological Survey Suzette M. Kimball, Acting Director}

\author{
U.S. Geological Survey, Reston, Virginia: 2014
}

For more information on the USGS — the Federal source for science about the Earth, its natural and living resources, natural hazards, and the environment, visit http://www.usgs.gov or call 1-888-ASK-USGS.

For an overview of USGS information products, including maps, imagery, and publications, visit http://www.usgs.gov/pubprod/

To order this and other USGS information products, visit http://store.usgs.gov/

Any use of trade, firm, or product names is for descriptive purposes only and does not imply endorsement by the U.S. Government.

Although this information product, for the most part, is in the public domain, it also may contain copyrighted materials as noted in the text. Permission to reproduce copyrighted items must be secured from the copyright owner.

Suggested citation:

Zarriello, P.J., and Barbaro, J.R., 2014, Hydraulic assessment of existing and alternative stream crossings providing fish and wildlife passage at seven sites in Massachusetts: U.S. Geological Survey Scientific Investigations Report 2014-5146, 36 p., http://dx.doi.org/10.3133/sir20145146.

ISSN 2328-0328 (online) 


\section{Acknowledgments}

The authors wish to thank Thomas Maquire of the Massachusetts Department of Environmental Protection Wetlands Program for his help in facilitating this study and site selection. The study was made possible through a Federal Clean Water Act Wetland Program development grant from the U.S. Environmental Protection Agency and the Massachusetts Subcouncil of the Housatonic River Trustee Council. Jane Winn of the Berkshire Environmental Action Team (BEAT) and Dennis Regan of the Housatonic Valley Association provided assistance with selection and information for the two sites in western Massachusetts. Survey work essential for the development of the hydraulic models was done by Andy Massey, Jason Sorenson, Marc Zimmerman, Lance Ostiguy, and Adam Hudziec of the U.S. Geological Survey. 



\section{Contents}

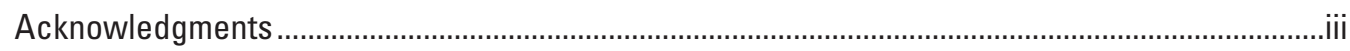

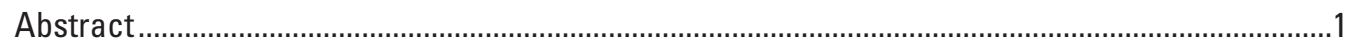

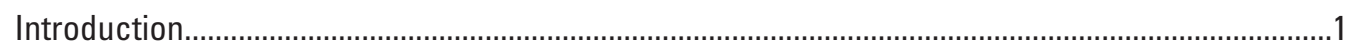

Purpose and Scope ......................................................................................................

Stream-Crossing Standards for Fish and Wildlife Passage ...................................................

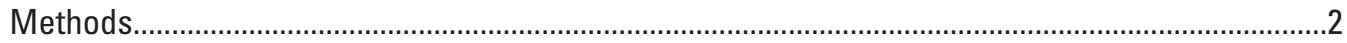

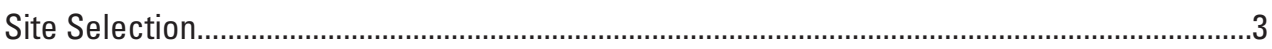

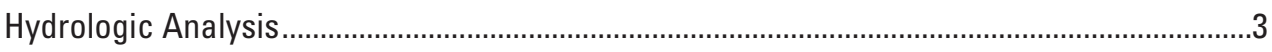

Hydraulic Analysis ...........................................................................................................

Hydraulic Assessment of Existing and Alternative Stream Crossings ..........................................14

Mill Brook at Church Street (Route 62) in Wilmington..........................................................15

Nashoba Brook at Main Street (Route 27) in Acton...............................................................18

Wading River at Richardson Avenue in Norton .................................................................21

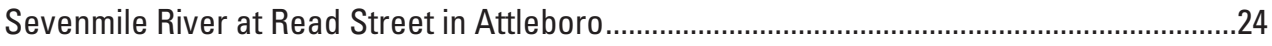

Segreganset River at Glebe Street in Taunton..................................................................26

Churchill Brook at Churchill Street and at Hancock Road in Pittsfield...................................29

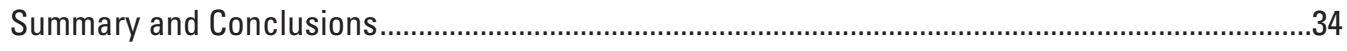

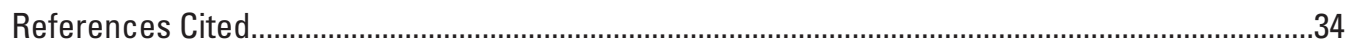

\section{Figures}

1. Map showing the location of sites used in the hydraulic analysis of stream crossings in Massachusetts.

2. Photograph of downstream face of Church Street (Route 62) crossing Mill Brook in Wilmington, Massachusetts

3. Photograph of upstream face of Main Street (Route 27) crossing Nashoba Brook in Acton, Massachusetts...

4. Photograph of downstream face of Richardson Avenue crossing Wading River in Norton, Massachusetts.

5. Photograph of upstream face of Read Street crossing Sevenmile River in Attleboro, Massachusetts

6. Photograph of downstream face of Glebe Street crossing Segreganset River in Taunton, Massachusetts.

7. Photographs of downstream faces of Churchill Brook crossings in Pittsfield, Massachusetts at $A$, Churchill Street, and $B$, Hancock Road.

8. Graphs showing upstream face cross section of Church Street (Route 62) at Mill Brook in Wilmington, Massachusetts: $A$, existing structure, and $B$, alternative stream crossing providing fish and wildlife passage

9. Graphs showing simulated Mill Brook water-surface elevation profiles at Church Street (Route 62) in Wilmington, Massachusetts: $A$, existing structure, and $B$, alternative stream crossing providing fish and wildlife passage...

10. Graphs showing upstream face cross section of Main Street (Route 27) at Nashoba Brook in Acton, Massachusetts: $A$, existing structure, and $B$, alternative stream crossing providing fish and wildlife passage. 
11. Graphs showing simulated Nashoba Brook water-surface elevation profiles at Main Street (Route 27) in Acton, Massachusetts: $A$, existing crossing, and

$B$, alternative stream crossing providing fish and wildlife passage

12. Graphs showing upstream face cross section of Richardson Avenue at Wading River in Norton, Massachusetts: $A$, existing structure, and $B$, alternative stream crossing providing fish and wildlife passage.

13. Graphs showing simulated Wading River water-surface elevation profiles at Richardson Avenue in Norton, Massachusetts: $A$, existing structure, and $B$, alternative stream crossing providing fish and wildlife passage.

14. Graphs showing upstream face cross section of Read Street at Sevenmile River in Attleboro, Massachusetts: $A$, existing structure, and $B$, alternative stream crossing providing fish and wildlife passage

15. Graphs showing simulated Sevenmile River water-surface elevation profiles at Read Street in Attleboro, Massachusetts: $A$, existing structure, and $B$, alternative stream crossing providing fish and wildlife passage...

16. Graphs showing upstream face cross section of Glebe Street at Segreganset River in Attleboro, Massachusetts: $A$, existing structure, and $B$, alternative stream crossing providing fish and wildlife passage.

17. Graphs showing simulated Segreganset River water-surface elevation profiles at Glebe Street in Taunton, Massachusetts: $A$, existing structure, and $B$, alternative stream crossing providing fish and wildlife passage.

18. Graphs showing upstream face cross section of Churchill Brook at Churchill Street in Pittsfield, Massachusetts: $A$, existing structure, and $B$, alternative stream crossing providing fish and wildlife passage.

19. Graphs showing upstream face cross section of Churchill Brook at Hancock Road in Pittsfield, Massachusetts: $A$, existing structure, and $B$, alternative stream crossing providing fish and wildlife passage.

20. Graphs showing simulated Churchill Brook water-surface elevation profiles at Churchill Street in Pittsfield, Massachusetts: $A$, existing structure, and $B$, alternative stream crossing providing fish and wildlife passage.

21. Graphs showing simulated Churchill Brook water-surface elevation profiles at Hancock Road in Pittsfield, Massachusetts: $A$, existing structure, and $B$, alternative stream crossing providing fish and wildlife passage.

\section{Tables}

1. Sites selected for a hydraulic assessment of existing and alternative stream crossings for fish and wildlife passage in Massachusetts

2. Total 24-hour rainfall for selected annual exceedance probabilities for selected areas in Massachusetts.

3. Flood flows at selected annual exceedance probabilities at stream-crossing sites in Massachusetts

4. Characteristics of the existing and simulated alternative stream-crossing structures in Massachusetts.

5. Hydraulic characteristics of simulated structures at the 10- and 1-percent annual exceedance probability flow for Mill Brook at Church Street (Route 62) in Wilmington, Massachusetts. 
6. Hydraulic characteristics of simulated stream-crossing structures at the 10- and 1-percent annual exceedance probability flow for Nashoba Brook at Glebe Street in Acton, Massachusetts.

7. Hydraulic characteristics of simulated structures at the 10- and 1-percent annual exceedance probability flow for Wading River at Richardson Avenue in Norton, Massachusetts.

8. Hydraulic characteristics of simulated stream-crossing structures at the 10- and 1-percent annual exceedance probability flow for Sevenmile River at Read Street in Attleboro, Massachusetts.

9. Hydraulic characteristics of simulated structures at the 10- and 1-percent annual exceedance probability flow for Segreganset River at Glebe Street in Taunton, Massachusetts.

10. Hydraulic characteristics of simulated stream-crossing structures at the 10- and 1-percent annual exceedance probability flow for Churchill Brook in Pittsfield, Massachusetts.

\section{Conversion Factors, Datum, and Abbreviations}

Inch/Pound to SI

\begin{tabular}{|c|c|c|}
\hline Multiply & By & To obtain \\
\hline \multicolumn{3}{|c|}{ Length } \\
\hline foot (ft) & 0.3048 & meter $(\mathrm{m})$ \\
\hline mile (mi) & 1.609 & kilometer $(\mathrm{km})$ \\
\hline \multicolumn{3}{|c|}{ Area } \\
\hline square foot $\left(\mathrm{ft}^{2}\right)$ & 0.09290 & square meter $\left(\mathrm{m}^{2}\right)$ \\
\hline square mile $\left(\mathrm{mi}^{2}\right)$ & 259.0 & hectare (ha) \\
\hline square mile $\left(\mathrm{mi}^{2}\right)$ & 2.590 & square kilometer $\left(\mathrm{km}^{2}\right)$ \\
\hline \multicolumn{3}{|c|}{ Flow rate } \\
\hline foot per second (ft/s) & 0.3048 & meter per second $(\mathrm{m} / \mathrm{s})$ \\
\hline cubic foot per second $\left(\mathrm{ft}^{3} / \mathrm{s}\right)$ & 0.02832 & cubic meter per second $\left(\mathrm{m}^{3} / \mathrm{s}\right)$ \\
\hline
\end{tabular}

Vertical coordinate information is referenced to the North American Vertical Datum of 1988 (NAVD 88).

Horizontal coordinate information is referenced to the North American Datum of 1983 (NAD 83).

Elevation, as used in this report, refers to distance above the vertical datum. 


\section{Abbreviations}

$\begin{array}{ll}\text { AEP } & \text { Annual exceedance probability } \\ \text { AOP } & \text { Aquatic organism passage } \\ \text { CN } & \text { Curve number } \\ \text { EMA } & \text { Expected moments algorithm } \\ \text { EMAadj } & \begin{array}{l}\text { Expected moments algorithm adjusted by extended period of record or } \\ \text { combined with regional equation values }\end{array} \\ \text { FEMA } & \text { Federal Emergency Management Agency } \\ \text { FIS } & \text { Flood insurance study } \\ \text { HEC-RAS } & \text { Hydrologic Engineering Center-River Analysis System } \\ \text { lidar } & \text { Light detection and ranging } \\ \text { MAeq } & \text { Massachusetts regional flood flow equations published in 1983 } \\ \text { MassDEP } & \text { Massachusetts Department of Environmental Protection } \\ \text { MassGIS } & \text { Massachusetts Office of Geographic Information } \\ \text { MOVE } & \text { Maintenance of variance extension } \\ \text { NAVD 88 } & \text { North American Vertical Datum of 1988 (vertical datum) } \\ \text { NERCC } & \text { Northeast Regional Climate Center (When used in context of flow it refers to } \\ \text { NRCS } & \text { rainfall-runoff model simulated flows using NERCC extreme rainfall data) } \\ \text { Rleq } & \text { Natural Resources Conservation Service } \\ \text { TC } & \text { Rhode Island regional flood flow equations published in 2012 } \\ \text { TP-40 } & \text { Time of concentration } \\ \text { TR-55 } & \text { Technical publication 40-Rainfall frequency atlas of the United States } \\ \text { USGS } & \text { morshfield, 1961) (When used in context of flow it refers to rainfall-runoff } \\ \text { WSE } & \text { TR-55 Rainfall-runoff model } \\ & \text { U.S. Geological Survey } \\ \text { Water-surface elevation }\end{array}$




\title{
Hydraulic Assessment of Existing and Alternative Stream Crossings Providing Fish and Wildlife Passage at Seven Sites in Massachusetts
}

\author{
By Phillip J. Zarriello and Jeffrey R. Barbaro
}

\section{Abstract}

Seven existing road crossing structures at streams in Massachusetts were evaluated hydraulically and compared to hypothetical alternative structures designed for Aquatic Organism Passage (AOP) using standards developed by the Massachusetts River Continuity Partnership. Hydraulic simulations made for flood flows ranging from 20 - to 0.2 -percent annual exceedance probability (AEP) indicate that the existing structures are at full capacity for many of the simulated AEP floods, causing appreciable backwater upstream from the structure, which exacerbates upstream flooding and causes road overflow in many cases. The existing structures also create an impediment to AOP by failing to meet standards for openness, height, span, and velocity.

Simulated hypothetical road crossing structures that provide for fish and wildlife passage by meeting or exceeding the AOP standards were able to convey most simulated AEP flood flows without causing appreciable backwater upstream from the structure. At sites where backwater was still present, it occurred only at the highest simulated flows and was compounded by the low downstream gradient that affected the water-surface elevation at the structure. The simulations of the alternative structures also indicate that, in addition to improved passage for fish and wildlife, the structures are more resilient to large floods and provide a greater buffer to uncertainties and potential changes in flood flows than the existing stream-crossing structures.

\section{Introduction}

Stream-crossing design is based on adequate conveyance of streamflows and, more recently, on ecological considerations that allow fish, other aquatic organisms, and wildlife in general to move up and down stream corridors. Knowledge of the magnitude of floods is needed for the effective and safe design of bridges, culverts, and roadbed elevations, but information on the flood magnitude for a given exceedance probability is largely out of date for most of the
Commonwealth of Massachusetts. Bridge and culvert sizing regulations rely on flood flows determined by design-storm hyetographs and rainfall-runoff models, regional flood-flow equations, or analysis of peak-flow records at streamgages. In Massachusetts, Federal Emergency Management Agency (FEMA) flood insurance studies (FIS) mostly conducted in the 1970s and 1980s often use flood flows determined with one of these methods. Recent studies have shown that the estimates may under-represent the magnitude of flood flows (Zarriello and Carlson, 2009; Zarriello and others, 2012; Armstrong and others 2012). Hyetographs used in the rainfall-runoff flood analyses are based on an extreme rainfall atlas of United States published in 1961 (Hershfield, 1961), which is considered outdated (Douglas and Fairbanks, 2011; Wilks and Cember, 1993). Other studies of flood magnitude used for bridge and culvert design rely on outdated regional flood-flow equations developed by Wandle $(1977,1983)$ or earlier or outdated flood-frequency analysis of streamgage peak-flow records.

In the past, Massachusetts stream-crossing standards did not explicitly consider fish and wildlife passage in their design. To preserve stream ecosystems, the Massachusetts River Continuity Partnership, a collaborative effort of the Massachusetts Department of Fish and Game, University of Massachusetts at Amherst, and others, developed new streamcrossing standards designed to minimize barriers to fish and wildlife passage (Singler and others, 2012; Jackson and others, 2011; Massachusetts Department of Transportation, 2010). The Massachusetts Wetlands Protection Act regulations currently require that stream crossings be designed to allow for passage of aquatic organisms and wildlife, which is generally referred to as Aquatic Organism Passage (AOP).

The hydraulic differences between existing stream crossings that were presumably designed to convey a specified flood flow and those designed to meet the AOP standards have received relatively little study. Because AOP standards call for wider and higher spans, they are able to convey higher flood flows with fewer adverse hydraulic effects (backwater, road flooding, or excessive scour) in addition to providing passage for aquatic organisms and wildlife. The objective of this study is to examine the hydraulic effects of existing structures and alternative structures that incorporate AOP standards by using 
steady-state, water-surface elevations (WSE) computed with a hydraulic model. The study also evaluates alternative flood flows of varying magnitudes determined by different methods at each of the study sites. A comparison of flood flows also is of interest because the extent of flood-prone land subject to jurisdiction by the Massachusetts Wetlands Protection Act regulations (310 CMR10.00) and sizing of stormwater controls to reduce peak runoff rates to wetlands are largely based on information developed approximately 30 to 50 years ago (1960-80). The study was done by the U.S. Geological Survey (USGS), in cooperation with the Massachusetts Department of Environmental Protection (MassDEP) through a Federal Clean Water Act Wetland Program Development Grant from the U.S. Environmental Protection Agency and the General Electric-Housatonic River Resources Massachusetts sub-council.

\section{Purpose and Scope}

This report presents hydraulic analyses of seven existing stream crossings in Massachusetts and hypothetical alternative stream crossings simulated to meet AOP standards. The hydraulic analyses include a comparison of WSE profiles for flood flows ranging from the 20- to the 0.2-percent annual exceedance probability (AEP). Flood flows used in the hydraulic analysis were determined by a variety of methods suited to each site and included flows from existing flood insurance studies, regional flood equations, streamgage peakflow analysis, and rainfall-runoff model simulated flows. Findings from this study can assist the MassDEP in evaluating the hydraulic performance and resiliency of AOP standards to flood flows.

\section{Stream-Crossing Standards for Fish and Wildlife Passage}

In the past, stream habitat continuity often was not a consideration in the design and construction of stream crossings. Consequently, many culverts and bridges in Massachusetts impose barriers to the movement of fish and wildlife. The stream-crossing standards developed by the River and Stream Continuity Partnership (http://www.streamcontinuity.org/ introduction/continuity partners.htm) are meant to facilitate the movement of fish and other aquatic organisms, maintain river and stream continuity (substrate and hydraulic characteristics), and allow for the movement of other wildlife species that may require dry passage along the streambanks during low to moderate flows (Singler and others, 2012; Jackson and others, 2011). The AOP standards are based on criteria for span width, openness, substrate material, and the maintenance of stream depth and velocity. Stream crossings designed to meet AOP standards maintain the continuity of the natural stream habitat important to the health and stability of aquatic, semi-aquatic, and terrestrial organisms.
Stream-crossing standards (Singler and others, 2012; MassDOT, 2010) are intended for the preservation of the natural stream channel (natural bottom substrate, water depth, and velocity similar to the natural channel at a variety of flows). AOP standards give preference to bridges, as they better preserve natural stream and streambank conditions, but open-arched or three-sided box, single barrel culverts are also acceptable if designed to preserve natural stream-channel conditions. Multiple barrel culverts are discouraged because the openness, stream velocities, and debris problems are often an impediment to fish and wildlife passage. Permits for all new stream crossings issued by the MassDEP require that crossings meet, where possible, a general standard or optimal standard in areas critical to rare and endangered species (Singler and others, 2012).

Stream crossing should be wide (span) and open. The general standard calls for the span to be a minimum of 1.2 times the bankfull width of the steam and the openness ratio (cross-sectional area divided by crossing length) of at least 0.82 feet (ft). For crossing with multiple openings, the openness ratio is determined from the largest opening. When openings are the same size, such as a road crossing with multibarrel culverts, the openness ratio is computed from the area of a single barrel. Span widths of 1.2 times bankfull width allow for dry passage for wildlife during low to moderate flow conditions. Optimum standards call for a minimum height between the streambed and the low chord of the span of $8 \mathrm{ft}$ and an openness ratio of $2.46 \mathrm{ft}$. Both minimal and optimum standards call for preservation of the natural channel substrate with water depths and velocities comparable to the natural stream channel. Culverts that do not have open bottoms should be avoided, but if used, they should be embedded at least $2 \mathrm{ft}$ into the stream channel and filled with natural channel material. The AOP standards allow for designs that balance the crossing cost and logistics with the degree of protection that is warranted. For this study, the hydraulic effects of the more optimum design standards typically were compared to the hydraulic effects of the existing structure.

\section{Methods}

Seven sites in Massachusetts were selected to evaluate the hydraulic characteristics of existing stream crossings structures and hypothetical alternative structures that provide for fish and wildlife passage. A hydrologic analysis was made at each site to determine magnitude of flood flows over a range of AEPs. A hydraulic analysis was then made using selected flood flows to determine the water-surface profile and other hydraulic characteristics of the existing and alternative streamcrossing structures. 


\section{Site Selection}

Potential sites were screened by the USGS and the MassDEP for suitability for a hydrologic and hydraulic analysis. The goal was to find sites that were not in conformance with AOP standards, were easily accessible, and were minimally affected by downstream structures or other features that would complicate the hydraulic analysis. Seven culvert sites were selected for further analysis (table 1). Five sites are in eastern Massachusetts - 1 in the northeastern, 1 in the centraleastern, and 3 in the southeastern part of the State. Two sites are on the same stream in the western part of the State (fig. 1).

All of the sites are in the upper parts of their associated basins with drainage areas ranging from 0.97 to 21.5 square miles $\left(\mathrm{mi}^{2}\right)$. Stream crossings associated with small drainage areas generally do not require large openings to convey flood flows and, therefore, tend to be undersized for fish and wildlife passage. In contrast, stream crossings associated with large drainage areas require large openings to convey a larger range of flows, which generally are better suited to provide fish and wildlife passage than stream crossings associated with small drainage areas. The selected stream crossings all failed to meet one or more of the AOP standards identified by the River and Stream Continuity Partnership (Single and others, 2012; Jackson and others, 2011). Details of the existing structures are described in the section "Hydrologic Analysis," along with details about alternative structures that meet AOP design standards.

\section{Hydrologic Analysis}

Hydrologic analysis refers to the determination of selected AEP flood flows. These flows then were used in the Hydrologic Engineering Center-River Analysis System (HEC-RAS) model to simulate steady-state WSEs for existing structures and alternative structures that meet AOP standards at each site. Flood flows were determined by various methods, depending on the available information for the site. If the method allowed, flows were estimated for the 20-, 10-, 2-, 1-, and 0.2-percent AEP. Flood flows published by FEMA for FISs were available for most sites except for Mill Brook in Wilmington and the Churchill Brook sites in Pittsfield. Although the published FEMA FISs are relatively recent, where available, the reported flood flows typically date from the mid-1970s to the early 1980s when the first FIS for an area was made. Peak flows reported in FISs were computed from streamgage records, if available for a reach. If the reach was ungaged, regional flood-flow equations or rainfall-runoff simulations with a 24-hour rainfall associated with a given AEP flood were used. Regional flood-flow equations for Massachusetts were last developed by Wandle (1983), but some FISs predate these equations and used equations by Johnson and Tasker (1974).

FISs that used rainfall-runoff models to generate flood flows were typically done with a relatively simple Natural Resources Conservation Service (NRCS) (formerly the Soil Conservation Service) model, such as TR-55 for small watersheds or TR-20 for large watersheds. However, details of model development often were not included in the FIS report. Total 24-hour rainfall from a 1961 atlas of rainfall frequencies in the United States, commonly referred to as TP-40 (Hershfield, 1961), were used to simulate corresponding AEP flood flows with the rainfall-runoff model using a type-III distribution. For this study, updated total 24-hour rainfall by the Northeast Regional Climate Center (NERCC) (DeGaetano and Zarrow, undated) was used at sites where rainfall-runoff models were used to determine flood flows. Applicable 24-hour rainfall at the sites in this study from TP-40 and NERCC are summarized in table 2. The updated NERCC extreme rainfall is considered to be more representative of current conditions than TP-40 extreme rainfall.

Table 1. Sites selected for a hydraulic assessment of existing and alternative stream crossings for fish and wildlife passage in Massachusetts.

[mi², square mile]

\begin{tabular}{lllcl}
\hline \multicolumn{1}{c}{ River } & \multicolumn{1}{c}{ Road } & \multicolumn{1}{c}{ Town } & $\begin{array}{c}\text { Drainage area } \\
\left(\mathbf{m i}^{\mathbf{2}} \mathbf{c}\right.\end{array}$ & \multicolumn{1}{c}{ Existing structure } \\
\hline Mill Brook & Church Street (Route 62) & Wilmington & 2.22 & Single box fieldstone culvert \\
Nashoba Brook & Main Street (Route 27) & Acton & 11.6 & Two circular corrugated metal culverts \\
Wading River & Richardson Avenue & Norton & 21.5 & Three circular corrugated metal culverts \\
Sevenmile River & Read Street & Attleboro & 7.28 & Three circular concrete culverts \\
Segreganset River & Glebe Street & Taunton & 0.97 & Single box fieldstone culvert \\
Churchill Brook & Churchill Street & Pittsfield & 1.13 & Single circular corrugated metal culvert \\
Churchill Brook & Hancock Road & Pittsfield & 1.18 & Two circular concrete culverts \\
\hline
\end{tabular}




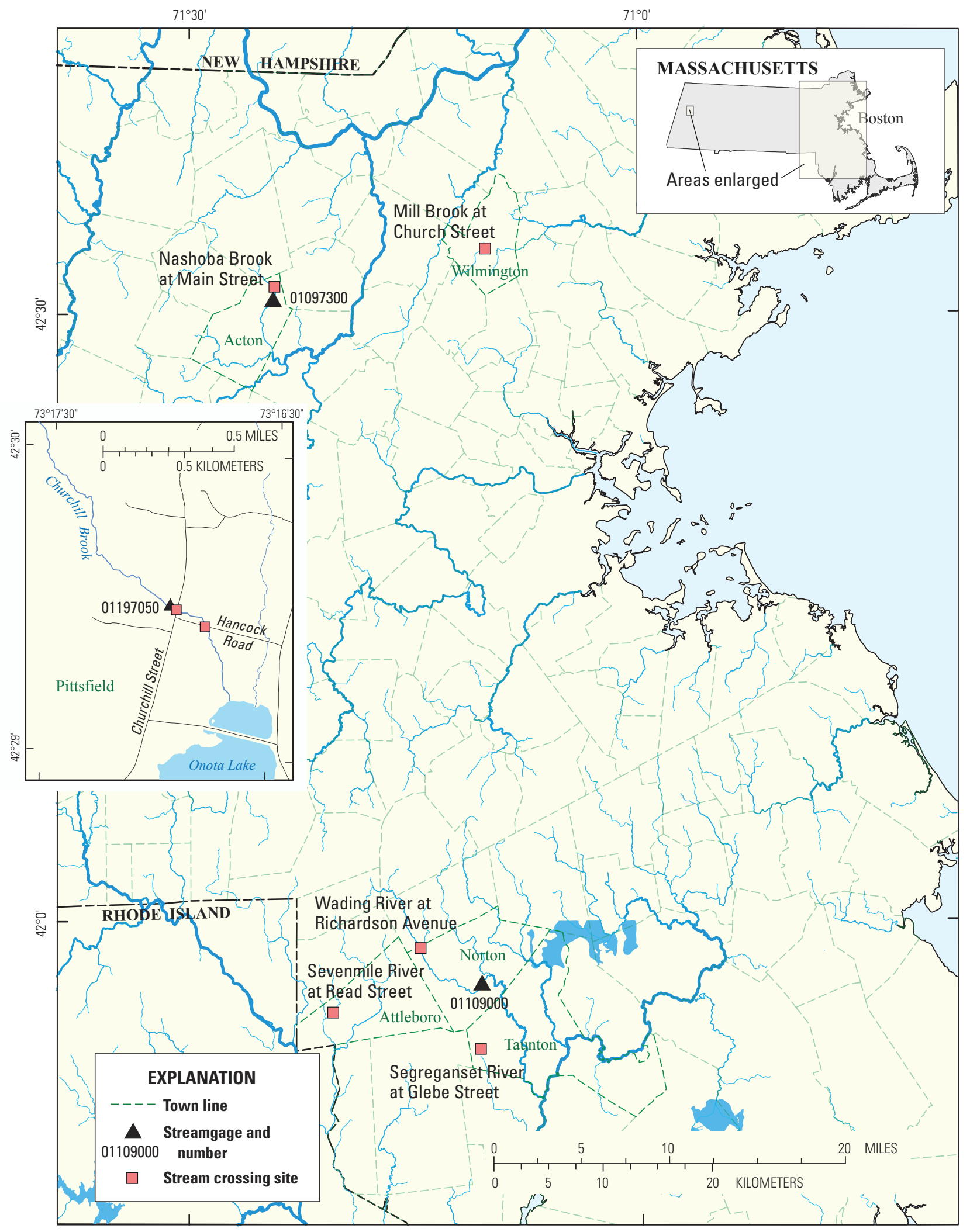

Figure 1. The location of sites used in the hydraulic analysis of stream crossings in Massachusetts. 
Table 2. Total 24-hour rainfall for selected annual exceedance probabilities for selected areas in Massachusetts.

$[--$, no data $]$

\begin{tabular}{|c|c|c|c|c|c|}
\hline \multirow{2}{*}{ Location and rainfall method } & \multicolumn{5}{|c|}{ 24-hour rainfall (inches) for specified percent annual exceedance probability } \\
\hline & 20 & 10 & 2 & 1 & 0.2 \\
\hline \multicolumn{6}{|c|}{ Taunton area } \\
\hline ТP-40 & 4.1 & 4.8 & 6.2 & 6.8 & -- \\
\hline $\mathrm{NERCC}^{2}$ & 4.1 & 4.9 & 7.4 & 8.8 & 13.3 \\
\hline Percent difference & 0 & 2.0 & 16 & 23 & -- \\
\hline \multicolumn{6}{|c|}{ Wilmington area } \\
\hline ТP- $40^{1}$ & 3.9 & 4.5 & 5.9 & 6.7 & -- \\
\hline $\mathrm{NERCC}^{2}$ & 4.0 & 4.8 & 7.4 & 8.8 & 13.5 \\
\hline Percent difference & 2.5 & 6.3 & 20 & 24 & -- \\
\hline \multicolumn{6}{|c|}{ Pittsfield area } \\
\hline ТP-40 & 3.8 & 4.5 & 5.1 & 5.8 & -- \\
\hline $\mathrm{NERCC}^{2}$ & 3.5 & 4.1 & 6.0 & 7.0 & 10.9 \\
\hline Percent difference & 7.9 & 8.9 & 15 & 17 & -- \\
\hline
\end{tabular}

${ }^{1}$ Technical Publication 40 (Hershfield, 1961) interpolated from isolines.

${ }^{2}$ Northeast Regional Climate Center (DeGaetano and Zarrow, undated).

Flood-flow estimates were determined at each site by two or more methods (table 3). The best estimates of flood flows were made from an at-site flood-frequency analysis where a long-term streamgage is near the site (Nashoba Brook and Wading River sites) and annual peak-flow data are available from the USGS National Water Information System (NWIS). Flood flows at these sites were determined using the expected moments algorithm (EMA) of the annual peak flows at the streamgage and then adjusted for differences in drainage area. EMA uses a log-Pearson type III distribution, which is similar to the guidelines for flood frequency analysis in Bulletin 17-B (Interagency Advisory Committee on Water Data, 1981) but includes enhancements for quantifying uncertainty for periods of no data (Cohn and others, 2001). Regional flood-flow equations developed for Rhode Island (Zarriello and others, 2012) were also considered a good estimate of flood flows for sites in southeastern Massachusetts (Wading and Sevenmile Rivers) because the equations were developed from a network of streamgages that includes streamgages from this region and were developed from the streamgage record through the 2010 water year ${ }^{1}$.

Less reliable estimates of flood flows were determined from regional flood-flow equations for small streams in Massachusetts and from rainfall-runoff simulations. The Massachusetts regional equations (Wandle, 1983) are considered outdated because the analysis was based on

${ }^{1} \mathrm{~A}$ water year is the 12-month period from October 1 to September 30; it is designated by the year in which it ends. streamgage data through the 1976 water year, and the methods used in that study have been superseded by more robust methods. Nonetheless, until new regional flood-flow equations are developed for Massachusetts, the Wandle (1983) equations may represent the best estimates of flood flows at some sites (Mill Brook and Segreganset River). Flood flows determined by rainfall-runoff model simulations used TR-55 (Natural Resources Conservation Service, 2009) and total 24-hr rainfall from TP-40 (Hershfield, 1961) or updated extreme rainfall (DeGaetano and Zarrow, undated) from the Northeast Regional Climate Center (NERCC) available at http://precip.eas.cornell.edu/ (herein referred to as TP-40 and NERCC flows, respectively). The TR-55 model simulated flows using TP-40, 24-hour, 1-percent AEP rainfall (table 2), also referred to as the 100-year return interval, at Mill Brook and Segreganset River sites (table 3) were "calibrated" to the 1-percent AEP flow determined from the Massachusetts regional equations (Wandle, 1983). The TR-55 simulated flows at Churchill Brook were "calibrated" to the at-site 1-percent AEP flow reported by Wandle (1983). The TR-55 model calibration is not a true calibration because the model was fit to another unknown. The NERCC, 24 hour, 1-percent AEP rainfall (table 2) was then used to simulate "updated" flood flows at these sites; however, no information was available to verify the accuracy of the simulated flows and the reliability of transferring a given AEP rainfall to generate a flood flow of an equal AEP. 
Table 3. Flood flows at selected annual exceedance probabilities at stream-crossing sites in Massachusetts.

[fts/s, cubic foot per second; $\mathrm{mi}^{2}$, square miles; USGS, U.S. Geological Survey; NERCC, Northeast Regional Climate Center; \%, percent; --, no data; FEMA, Federal Emergency Management Agency; FIS, Flood Insurance Study; EMA, expected moments algorithm. Green shaded cells are generally considered the best estimate of flood flows used in hydraulic analysis; orange shaded cells are flood flows used in the hydraulic analysis that generally represent a higher estimate of flow]

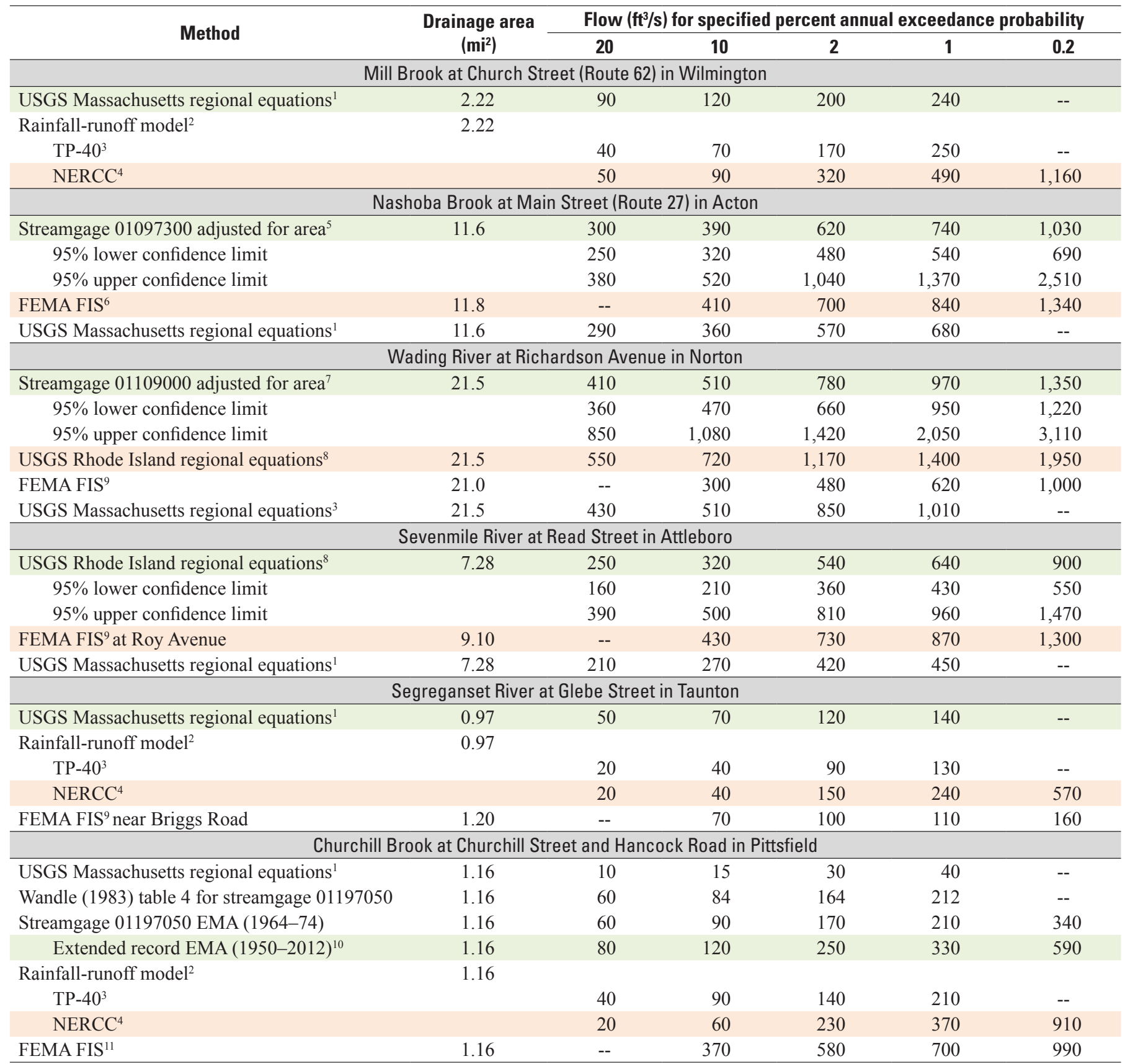

${ }^{1}$ Regional flood-flow equations for Massachusetts (Wandle, 1983), equations 1-6.

${ }^{2}$ TR-55 rainfall-runoff model (National Resources Conservation Service, 2009).

${ }^{3}$ Extreme rainfall from Technical Publication-40 (Hershfield, 1961).

${ }^{4}$ Extreme rainfall from Northeast Regional Climate Center (DeGaenano and Zarrow, undated).

${ }^{5}$ Nashoba Brook at Acton (1964-2012) expected moments algorithm analysis adjusted for drainage area.

${ }^{6}$ FEMA, 2010, Flood Insurance Study no. 25017CV001A.

${ }^{7}$ Wading River at Norton (1925-2012) expected moments algorithm analysis weighted by regional regression equations and adjusted for drainage area.

${ }^{8}$ Regional flood-flow equations for Rhode Island (Zarriello and others, 2012), equations 2-8.

${ }^{9}$ FEMA, 2012, Flood Insurance Study no. 25005CV001B.

${ }^{10}$ Maintenance of variance extension (MOVE) (Hirsch, 1982) using Green River at Williamstown (01333000).

${ }^{11}$ FEMA, 1987, Flood Insurance Study no. 250037, interpolated from flows at $1.0 \mathrm{mi}^{2}$ for Battle, Wampenum, and Wild Acres Brooks adjusted to $1.15 \mathrm{mi}^{2}$. 
Mill Brook at Church Street flood flows could be determined only by use of the Massachusetts regional equations or by TR-55 simulations. The TR-55 model simulated a single drainage basin with a "calibrated" weighted curve number $(\mathrm{CN})$ of 49 and a time of concentration (TC) of 5.9 hrs. At the 1-percent AEP flow, the TP- 40 generated flow was about 4 percent larger than the flow computed from the Massachusetts regional equation. The NERCC generated flows were 29-, 88-, and 96-percent larger than the TP-40 generated flows at the 10-, 50-, and 1-percent AEP, respectively. The NERCC generated flows were used as the upper estimate of flood flows, and the Massachusetts regional equations were used as the best and lower estimate of flood flows in the hydraulic analysis at Church Street (table 3). Given the uncertainties of flood-flow estimates, the best and upper estimates of flood flows were simulated in the hydraulic model at each site to show the potential range of stage and velocity at the stream crossing.

Nashoba Brook at Main Street (Rt. 27) flood flows were computed from an analysis of a 49-year record (1964-2012) of annual peak flows at the Nashoba Brook at Acton streamgage (01097300) using EMA. No interval data or perception thresholds were applied to the Nashoba Brook streamgage analysis. The EMA results were adjusted for drainage area at Main Street $\left(11.6 \mathrm{mi}^{2}\right)$ relative to the streamgage $\left(11.8 \mathrm{mi}^{2}\right)$ using a simple drainage area ratio raised to an exponent of 0.81 to 0.76 for 20 - to 0.2 -percent AEP flows, respectively (Zarriello and others, 2012; equation 22). Annual peak flows at the Nashoba Brook streamgage have a positive trend, but the trend is not significant. The area-adjusted flows from the EMA analysis (table 3 ) used in the hydraulic analysis are considered the best estimates of flood flows at Main Street. The flood flows reported for this site in the FIS (FEMA, 2010) were used in the hydraulic analysis as an upper estimate of flows (table 3). The source of flows reported in the FIS is uncertain but appears to be from a preliminary flood-frequency study by Johnson and Tasker (1974). FIS reported flows were about 5-, 13-, 14-, and 30-percent higher than the EMA adjusted flows for 10-, 2-, 1-, and 0.2-percent AEP floods, respectively. Flood flows computed using the Massachusetts regional equations (table 3) are comparable to the area adjusted at-site analysis but were not used in the hydraulic model simulations.

Wading River at Richardson Avenue flood flows were computed from an analysis of an 86-year record (1925 to 2010) of annual peak flows at the Wading River near Norton streamgage (01109000) weighted by Rhode Island regional flow equation flows and adjusted for drainage area at Richardson Avenue (table 3). No significant trend was detected in annual peak flows at the Wading River streamgage. Weights were assigned on the basis of the computed uncertainty of each method (Zarriello and others, 2012; table 13). The drainage area at Richardson Avenue $\left(21.5 \mathrm{mi}^{2}\right)$ relative to the streamgage $\left(43.3 \mathrm{mi}^{2}\right)$ was adjusted using a simple drainage area ratio raised to an exponent of 0.81 to 0.76 for 20- to 0.2-percent AEP flows, respectively (Zarriello and others, 2012; equation 22). The ratio of the ungaged to gaged drainage areas $(0.51)$ is outside the recommended range (0.6-1.4) for application of this method, but this was still considered the best estimate of flood flows at Richardson Avenue. The weighted area-adjusted flood flows were about 30 to 40 percent lower than the values computed with the regional Rhode Island equations for 10- to 0.2-percent AEP flows but were comparable to flows computed with the Massachusetts regional equations (table 3 ). The hydraulic analysis used the flows computed with the Rhode Island regional equations as the upper estimate of flows at Richardson Avenue. The 2012 FIS reported flood flows (FEMA, 2012) are about 41 to 26 percent lower than the area-adjusted EMA flood flows for 10- to 0.2-percent AEP flows, respectively.

Sevenmile River at Read Street flood flows were computed by use of the Rhode Island regional equations and the Massachusetts regional equations. Flood flows computed with the Massachusetts regional equations were about 20 percent lower than those computed with the Rhode Island regional equations, which may reflect the increases in the magnitude of floods in the 35 years of additional data used in the Rhode Island equations. The flood flows reported in the 2012 FIS (FEMA, 2012) applied at Read Street (table 3) were determined downstream at Roy Avenue $\left(9.1 \mathrm{mi}^{2}\right)$. The FIS flows adjusted for the drainage area at Read Street $\left(7.3 \mathrm{mi}^{2}\right)$ were about 34-, 35-, 36-, and 44-percent higher than the flows computed with the Rhode Island regional equations for the 10-, 2-, 1-, and 0.2-percent AEP flows, respectively. Although the FEMA flood flows were from a recent FIS (FEMA, 2012), the report states that flows for the City of Attleboro (including Sevenmile River at Read Street) were completed in June 1977 by the Soil Conservation Service (now known as the NRCS). No information was given in the FIS regarding the method used to estimate flows, but they are believed to have been determined by a rainfall-runoff model simulating TP-40 rainfall. The hydraulic analysis used the FIS flood flows as the upper estimate of flows and the Rhode Island regional equation flows as the lower and best estimate of flood flows at Read Street.

Segreganset River at Glebe Street flood flows were computed with the Massachusetts regional equations and with TR-55 using total 24-hr rainfall from TP-40 and NERCC for the Taunton area (table 3). The TR-55 model simulated a single drainage basin with a "calibrated" weighted $\mathrm{CN}$ of 47 and a TC of $5.0 \mathrm{hrs}$. The TP-40 generated flow was about 7 percent less than the flow computed with the regional equation at the 1-percent AEP. The TP-40 generated flows are similar to the reported FIS flows (FEMA, 2012) for this reach, which were computed by similar methods. The NERCC generated flows increased in direct proportion to the differences in TP-40 and NERCC rainfall; at the 10-, 2-, and 1-percent AEP, the NERCC generated flows were 0-, 67-, and 85-percent higher than the TP-40 generated flows, respectively. The NERCC generated flows were used as the upper estimate of flows and the Massachusetts regional equations were used as the best and lower estimate of flows in the Glebe Street crossing hydraulic analysis (table 3). Note 
that, although the Rhode Island regional flood equations (Zarriello and others, 2012) are applicable in this area, the equations were not used because the basin characteristics at the site are well outside the range of applicable limits.

Churchill Brook at Churchill Street and at Hancock Road flood flows were computed as a single flow for each AEP using a drainage area of $1.16 \mathrm{mi}^{2}$. Drainage areas at Churchill Street $\left(1.13 \mathrm{mi}^{2}\right)$ and at Hancock Road $\left(1.18 \mathrm{mi}^{2}\right)$ are similar enough to not warrant separate computations of flow. AEP flood flows were computed with the Massachusetts regional equations, extended record analysis using EMA, and with TR-55 using total 24-hr rainfall from TP-40 and NERCC for the Pittsfield area (table 3). Explanatory variables used to compute the Massachusetts regional equations were near the range of the applicable limits and likely were the cause of considerably lower flows for given AEPs compared to other methods. A partial-record streamgage on Churchill Brook (01197050) that operated from 1963 to 1974 was used by Wandle (1983) to compute AEP flood magnitudes from the at-site analysis (table 3) as part of regional peak-flow equation development. Because of the limited record (11 years), the maintenance of variance extension (MOVE) by Hirsch (1982) was used to extend the record using Green River at Williamstown (01333000) for the EMA analysis. Several nearby long-term streamgages were tested in the MOVE analysis, but the Green River streamgage yielded the lowest root mean square error of simulated flow relative to observed flows. The extended record EMA analysis resulted in AEP flows that were 33 to 74 percent higher than the same AEP flow determined from the period of record analyses. The extended record EMA analyses are considered the best estimate of AEP flood flows used in the hydraulic analyses.

AEP flood flows at Churchill Brook also were computed using TR-55 as a single drainage basin with a weighted CN of 51 and a TC of $1.8 \mathrm{hrs}$. The TP-40 generated flow was about equal to the 1-percent AEP flow computed by the at-site analyses for the period of record. The NERCC generated flows for the 2- and 1-percent AEP were 64 and 73 percent higher, respectively, compared to TP-40 generated flows. The NERCC generated flows (table 3) were used as the upper estimate of AEP flows. The average FIS flows for small basins in the Pittsfield area (FEMA, 1987) were comparable to the NERCC generated flow at the 0.2-percent AEP but were considerably larger for floods with a greater AEP (table 3). FIS flows were computed from average flood flows reported for Brattle, Wild Acre, and Wampenum Brooks in the City of Pittsfield (FEMA, 1987) at $1 \mathrm{mi}^{2}$ and adjusted for drainage area.

\section{Hydraulic Analysis}

The hydraulic analysis of the stream crossings mainly consisted of simulating WSE profiles for selected AEP flood flows for the existing structures and alternative structures that meet AOP guidelines. The analysis includes a comparison of backwater, road flooding, and stream velocities for the different structures. Steady-state flow through structures was simulated with HEC-RAS version 4.1.0 (Brunner, 2010a, b), a one-dimensional hydraulic model. The carrying capacity or conveyance of the stream was determined using surveyed channel geometry at the approach and exit to the structure, surveyed geometry of the structure, energy losses from channel and overbank roughness, and contraction and expansion of flow near the structure. Additional channel cross sections were defined upstream and downstream from the structure to better define energy losses. The flows simulated in the models were determined for selected AEP floods as previously described. The downstream boundary was set to the normal depth determined from channel or water-surface slope at the downstream cross section, except for the Churchill Brook model where the elevation of the lake into which the reach drains was used. The downstream cross section was far enough downstream from the structure to minimize the effects of the boundary condition on the WSE near the structure, although the downstream boundary still had an influence on the water-surface profile at some structures because of low stream gradients. For sites where the downstream gradient and boundary condition affected WSE at the structure, the effect was consistent for both of the structures simulated. All WSEs in this study are referenced to feet above North American Vertical Datum of 1988 (NAVD 88).

HEC-RAS simulates the WSE at a structure by computing energy losses immediately downstream from the structure, losses at the structure, and losses immediately upstream from the structure. Four user-defined cross sections are required to simulate energy losses - the exit from the structure after the flow is fully expanded, the downstream and upstream faces of the structure, and the approach to the structure before the flow contracts. Two interpolated internal cross sections are created by the model to simulate energy losses inside the structure. Although a minimum of four cross sections are required by the model to simulate the hydraulic effects of a structure, additional cross sections were specified upstream and downstream from the structure to capture all the energy losses. The crosssection spacing near the structure was determined on the basis of the existing structure geometry.

Ineffective flow areas in the model cross sections near the structure were determined using the general 1:1 ratio rule (Brunner, 2010b) for expansion and contraction on the basis of the distance of the cross section from the edges of the structure opening. The upstream height of the ineffective flow areas typically was set to the height of the lowest road elevation. Expansion and contraction coefficients and roughness coefficients were assigned standard values for the observed conditions (Brunner, 2010b). However, only field observations under high flow conditions reveal the actual ineffective flow dimensions and other coefficients required by the model, which was beyond the scope of the project.

The simulations assume the stream crossings are free of obstructions, but given the size of the existing structures and multiple openings at some sites, flow through the structure is likely obstructed during floods. As such, the actual WSE 
upstream from the structure will be affected, and the actual WSE will be greater than the simulated WSE. The magnitude of the difference depends on the extent of the obstruction. The crossings designed to meet AOP standards are less likely to be affected by obstructions because their openings are larger than the existing structure and better conform to the shape of the natural stream channel. The alternative structures were simulated as bridges because the stream-bottom profile interpolated from the downstream and upstream face profiles would be preserved within the structure, which better represents the AOP standards.

All models of natural systems are simplifications of actual conditions and are constrained by the limitations of the model and the uncertainty of the values representing actual conditions. In this study, absolute WSEs are considered to be uncertain because data, such as measured flood flows and associated high-water marks, were not available to adjust the model parameter values and verify the model calibration. The models developed for this study use detailed site-specific cross section and structure geometry data, incorporate standard modeling approaches and parameter values, and therefore, are considered to provide reasonable representations of the hydraulic effects of existing and alternative structures.

Sevenmile and Wading River site structures, road elevations, and approach and exit channel sections were recently surveyed (2012) as part of a collaborative USGS-FEMA flood mapping study and were used in the development of hydraulic models in this study. Similar field surveys were made at Churchill Brook, Mill Brook, Nashoba Brook, and Segreganset River sites to develop the hydraulic models for this study. All field surveying was done in accordance with FEMA standards for flood-hazard mapping (FEMA, 2011). In addition, recent light detection and ranging (lidar) elevation data (accurate vertical ground-surface elevation within $\pm 0.5 \mathrm{ft}$ for every pixel nominally spaced every 2 meters) obtained from either the USGS-FEMA study or Massachusetts Office of Geographic Information (MassGIS) were used to better define the overbank geometry of the cross sections in the HEC-RAS models that were not recently field surveyed. For cross sections upstream and downstream from the approach and exit sections, respectively, channel elevation data were not available; at these locations channel elevations were approximated from nearby surveyed channel elevations, lidar data, and assumed water depths (lidar used for land elevation does not penetrate through water).

The HEC-RAS model for Mill Brook at Church Street (Route 62) in Wilmington represents a 1,530-ft reach consisting of 3 upstream and 4 downstream cross sections from Mill Street plus a section representing the stream crossing. The existing structure is a single box culvert $6 \mathrm{ft}$ wide by $3.5 \mathrm{ft}$ high and $50 \mathrm{ft}$ long. The structure is set in a vertical fieldstone and concrete headwall (fig. 2). The sides of the culvert are constructed of fieldstone topped by concrete; the bottom appears to be open, consisting of natural channel material. Manning's roughness coefficients (n) in the model are 0.035 and 0.020 for the bottom and sides of the culvert, respectively, 0.035 for the channel, and 0.070 to 0.090 for the streambank and overbank areas. The downstream boundary was set to the normal depth with a slope of $0.001 \mathrm{ft} / \mathrm{ft}$ estimated from lidar topography and the presence of wetlands.

The HEC-RAS model for Nashoba Brook at Main Street (Route 27) in Acton represents a 1,580-ft reach consisting of 4 upstream and 5 downstream cross sections from Main Street plus a section representing the stream crossing. The existing structure consists of two 6-ft diameter, $40-\mathrm{ft}$ long corrugated metal culverts set in a vertical, concrete headwall (fig. 3). Manning's $n$ values in the model are 0.019 for the culverts, 0.035 for the channel, and 0.090 for the streambank and overbank areas. The downstream boundary was set to the normal depth with a slope of $0.0005 \mathrm{ft} / \mathrm{ft}$ estimated from lidar topography and the presence of wetlands. Because of the low stream gradient, the downstream boundary affects the simulated WSE profile at Main Street at most flows.

The HEC-RAS model for Wading River at Richardson Avenue in Norton was modified from an existing HEC-RAS model of the Wading River under development by USGS for a flood mapping project. The modified model represents a 4,330-ft reach consisting of 3 upstream and 5 downstream cross sections from Richardson Avenue plus a section representing the stream crossing. The existing structure consists of three 5 -ft diameter, $40-\mathrm{ft}$ long corrugated metal culverts set in a vertical, concrete headwall (fig. 4). Manning's n values in the model are 0.021 for the culverts, 0.035 for the channel, and 0.090 for the streambank and overbank areas. The downstream boundary was set to the normal depth with a slope of $0.003 \mathrm{ft} / \mathrm{ft}$ determined from downstream cross sections in the larger Wading River HEC-RAS model under development.

The HEC-RAS model for Sevenmile River at Read Street in Attleboro was modified from an existing HEC-RAS model of the Sevenmile River under development by USGS as part of a flood mapping project. The modified model represents a 3,590-ft reach consisting of 4 upstream and 6 downstream cross sections from Read Street plus a section representing the stream crossing. The existing structure consists of three 5 -ft diameter, 29-ft long concrete culverts set in a vertical, mortared stone headwall (fig. 5). The culverts are at a slight angle to the road but are not sufficiently angled to skew the structure in the model. A utility pipe on the left bank a short distance upstream from the culvert partially blocks flow and was simulated by a larger than normal ineffective flow area on that side of the structure. The Manning's $n$ values in the model are 0.011 for the culverts, 0.035 for the channel, and 0.060 to 0.080 for the streambank and overbank areas. The downstream boundary was set to the normal depth with a slope of $0.002 \mathrm{ft} / \mathrm{ft}$ estimated from downstream cross sections in the FIS.

The HEC-RAS model for Segreganset River at Glebe Street in Taunton represents a 1,850-ft reach consisting of 3 upstream and 4 downstream cross sections from Glebe Street plus a section representing the stream crossing. The existing structure is a single box culvert $4 \mathrm{ft}$ wide by $4 \mathrm{ft}$ high, and $40 \mathrm{ft}$ long. The culvert and headwall are constructed of 


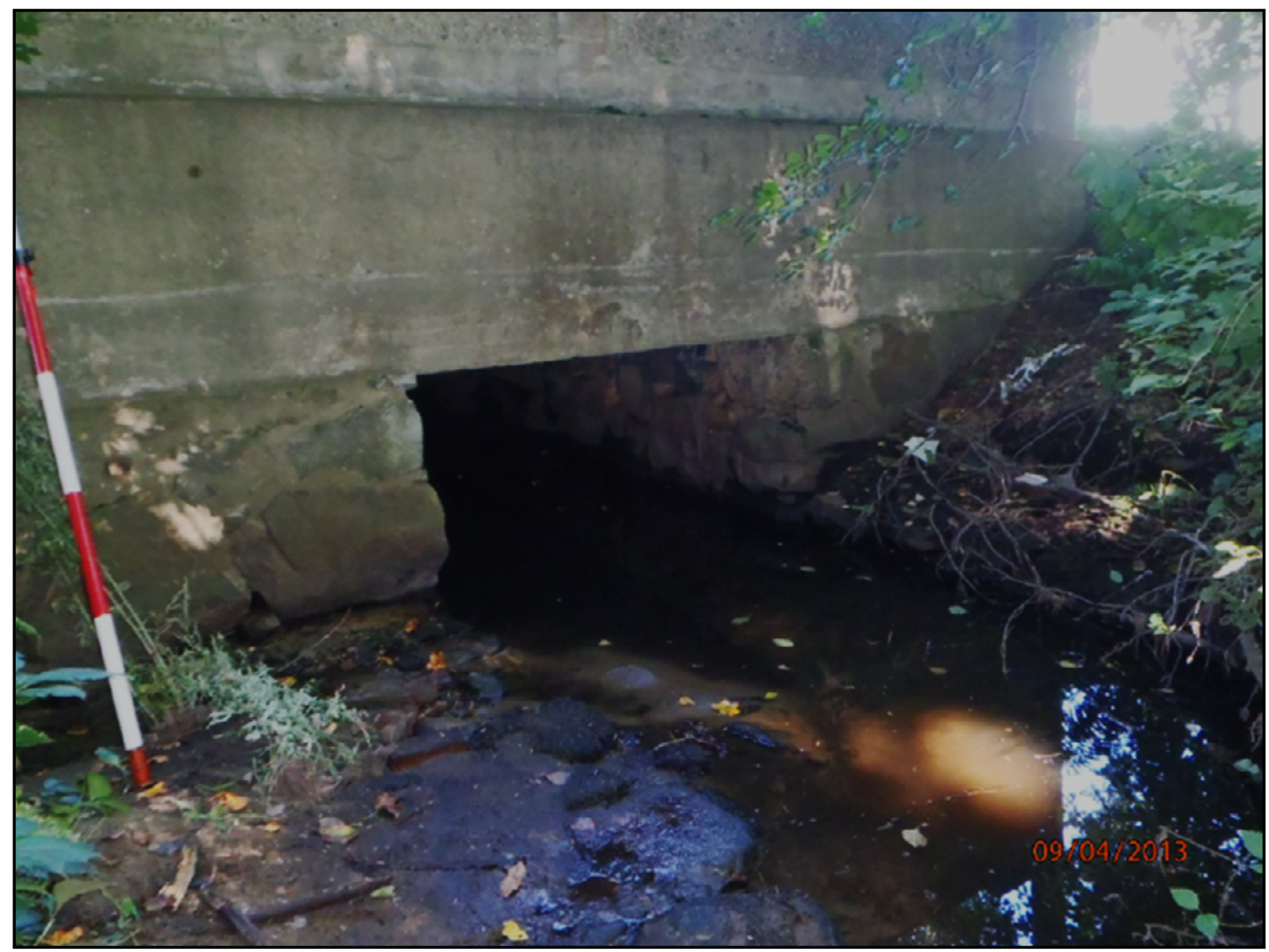

Figure 2. Downstream face of Church Street (Route 62) crossing Mill Brook in Wilmington, Massachusetts.

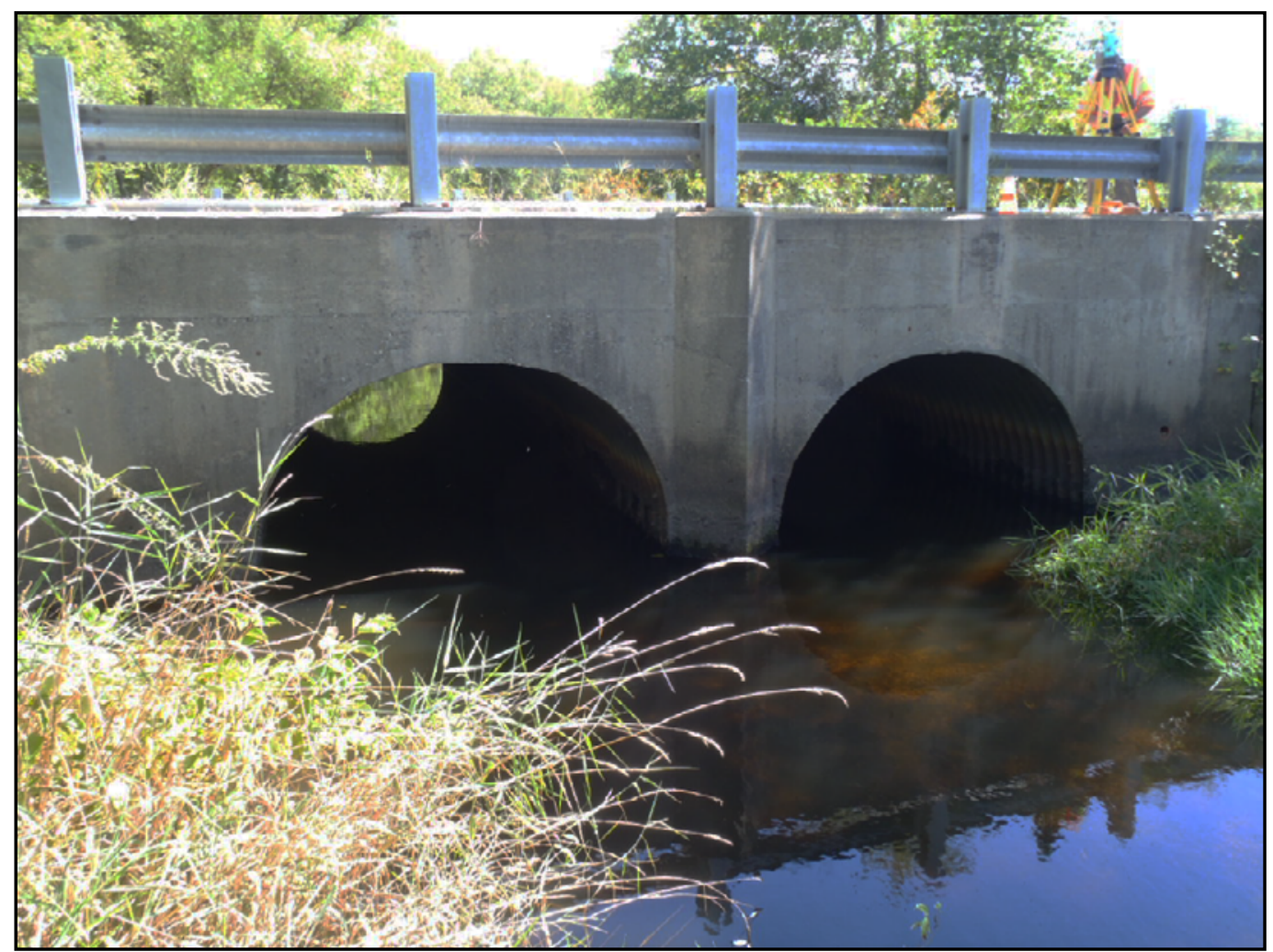

Figure 3. Upstream face of Main Street (Route 27) crossing Nashoba Brook in Acton, Massachusetts. 


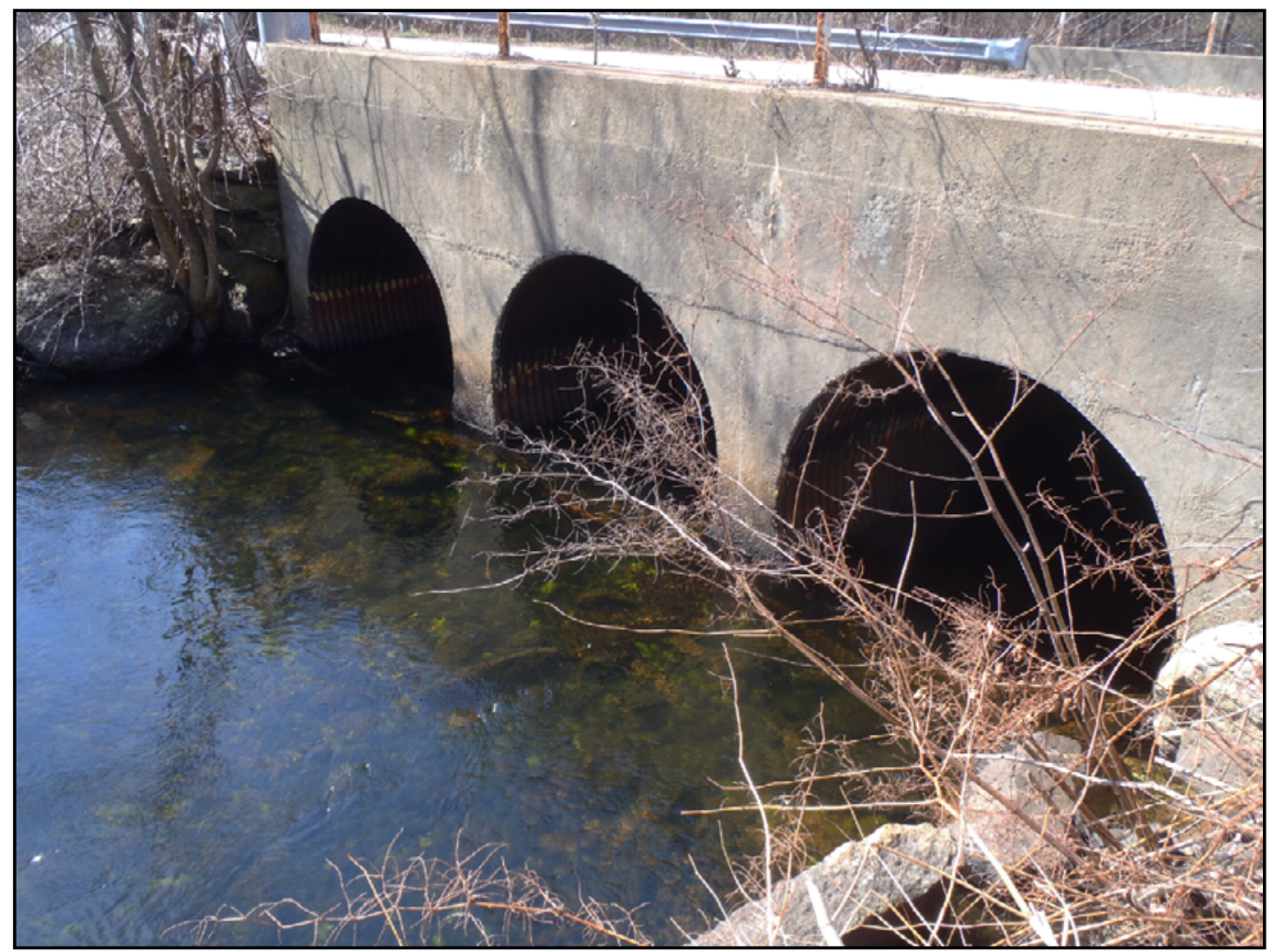

Figure 4. Downstream face of Richardson Avenue crossing Wading River in Norton, Massachusetts.

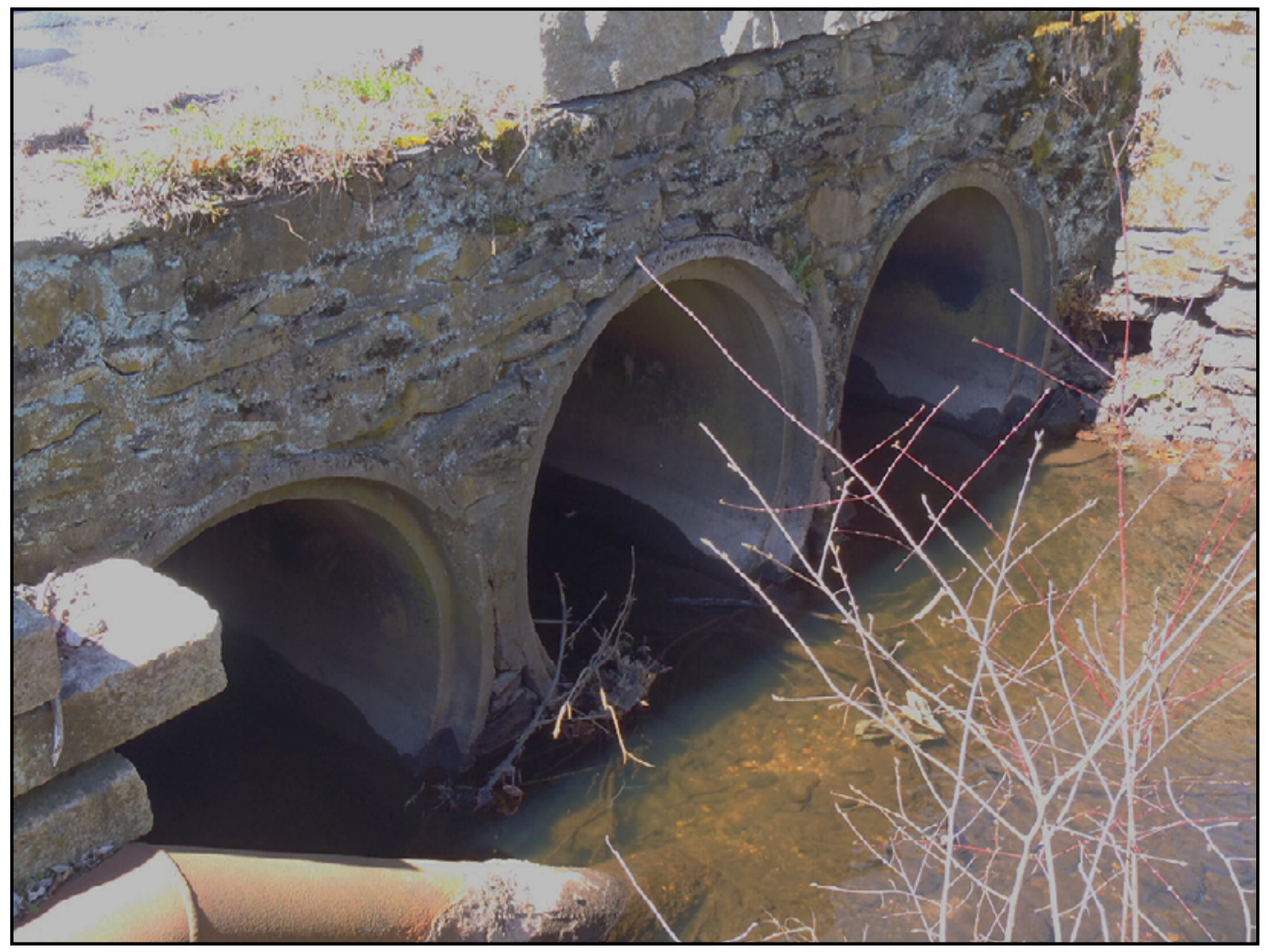

Figure 5. Upstream face of Read Street crossing Sevenmile River in Attleboro, Massachusetts. 
fieldstone with an open bottom consisting of natural channel material (fig. 6). Manning's n values in the model are 0.035 for the bottom and sides of the culvert, 0.035 for the channel, and 0.070 to 0.090 for the streambank and overbank areas. The downstream boundary was set to the normal depth with a slope of $0.0016 \mathrm{ft} / \mathrm{ft}$ estimated from the lidar topography.

The HEC-RAS model for Churchill Brook in Pittsfield was simulated with a single 4,170 -ft reach with streamcrossing structures at Churchill Street and at Hancock Road. The model consists of 3 cross sections upstream from Churchill Street, 3 cross sections between Churchill Street and Hancock Road, and 3 cross sections downstream from Hancock Road. Manning's $n$ values for the open channel was set at 0.038 and ranged from 0.070 to 0.090 for the streambank and overbank areas. The existing structure at Churchill Street consists of a single 47-ft long, 4-ft diameter corrugated metal culvert that is partially collapsed at the downstream end (fig. 7A). The upstream end of the culvert is faced with field stone and has a rectangular opening about $4 \mathrm{ft}$ wide by $3 \mathrm{ft}$ high. The downstream end of the culvert is believed to cause the greater flow constriction. To mimic this constriction, the diameter of the culvert in the HEC-RAS model was decreased to $3.3 \mathrm{ft}$, which was used to estimate the open area of the partially collapsed culvert. Manning's n for Churchill Street culvert was set at 0.014 .
The existing structure at Hancock Road consists of two 30 -ft long, 2.5 -ft diameter concrete culverts with fieldstone headwalls (fig. 7B). Manning's $n$ for Hancock Road culverts was set at 0.012 . The culverts have about a 20 degree skew relative to the road, but because skews of less than 30 degrees have little effect on flow (Brunner, 2010b), a skew was not specified in the model. A declining road elevation to the east of Churchill Brook complicates the computation of water levels because the road elevation drops to about the same elevation as the bottom of the culverts. The lowest road elevation in the cross section starts about $120 \mathrm{ft}$ to the east of the stream and continues for about $80 \mathrm{ft}$. As such, the model would simulate the majority of the flow as weir flow over this section of the road without modifications to restrict flow to the east of the culverts. Field observations and the surveyed upstream and approach cross sections indicate that a built-up left embankment upstream from the road confines streamflow through the culverts until water levels rise above the embankment; however, it's not known whether the brook overflows its embankment farther upstream, allowing secondary channel flow over the low road elevation to the east. Without additional information, it was assumed that most flow passes through the culverts or spills over the road at the culverts. This allows for more direct comparative hydraulic analysis of the existing structure to an alternative

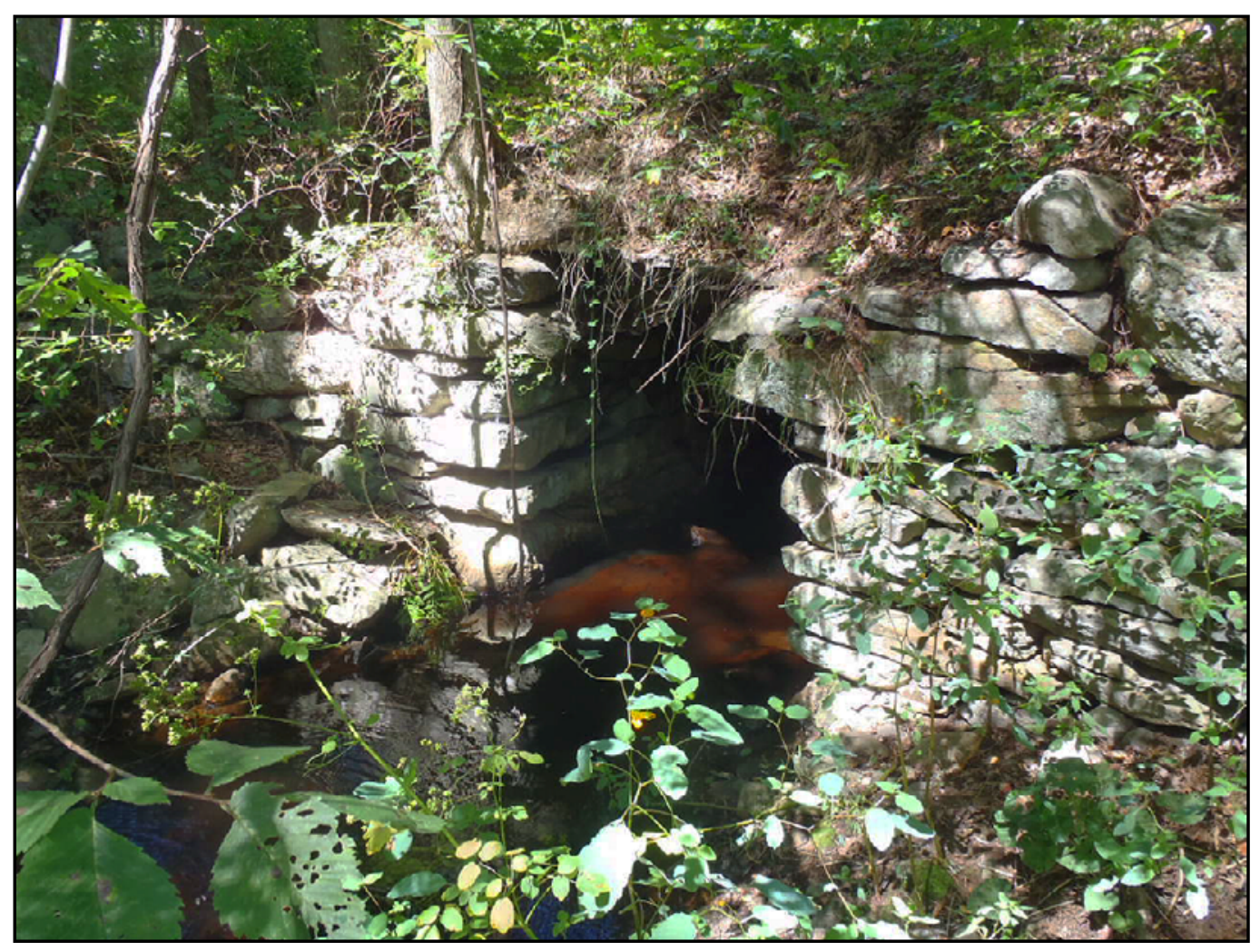

Figure 6. Downstream face of Glebe Street crossing Segreganset River in Taunton, Massachusetts. 


\section{A. Churchill Street}

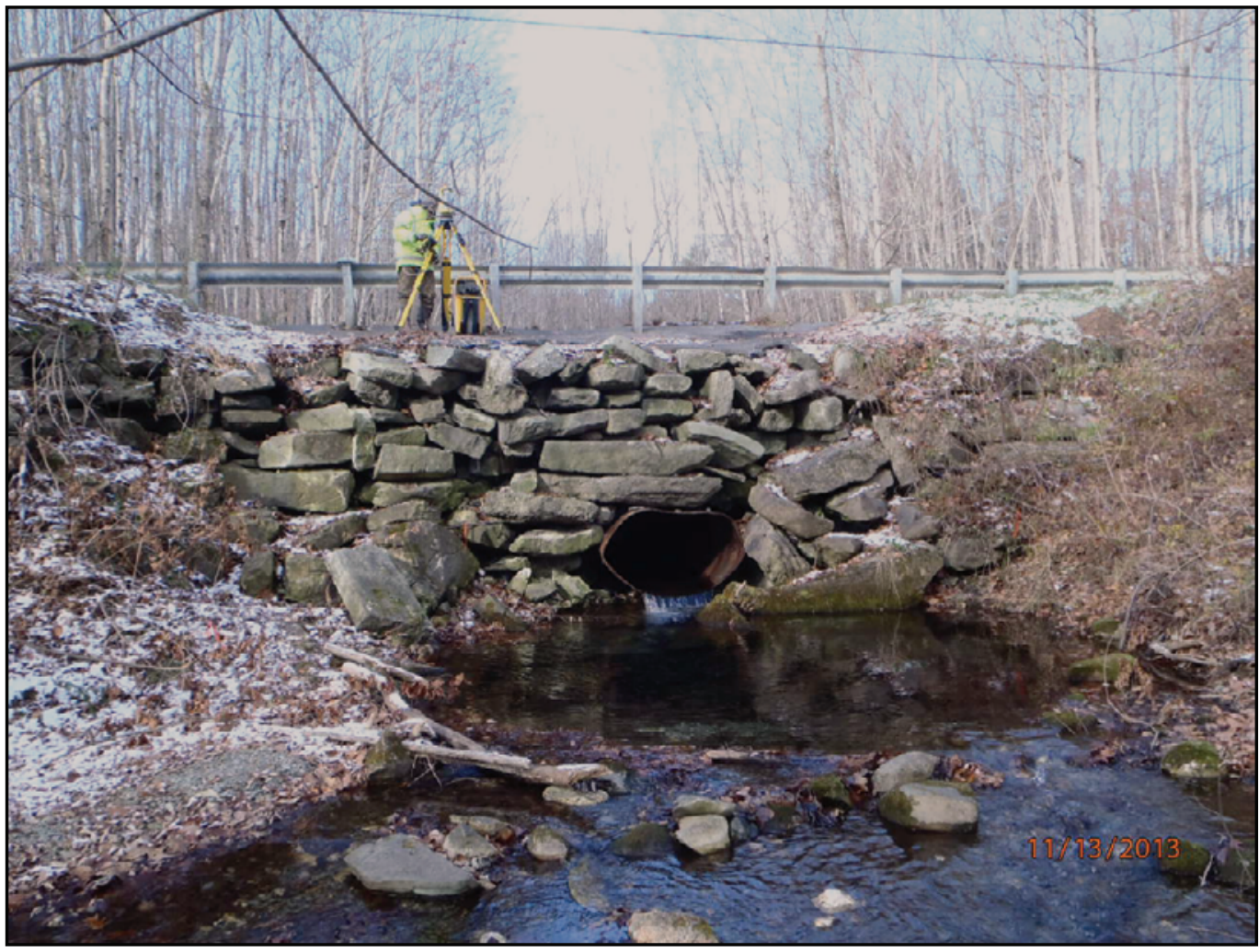

\section{B. Hancock Road}

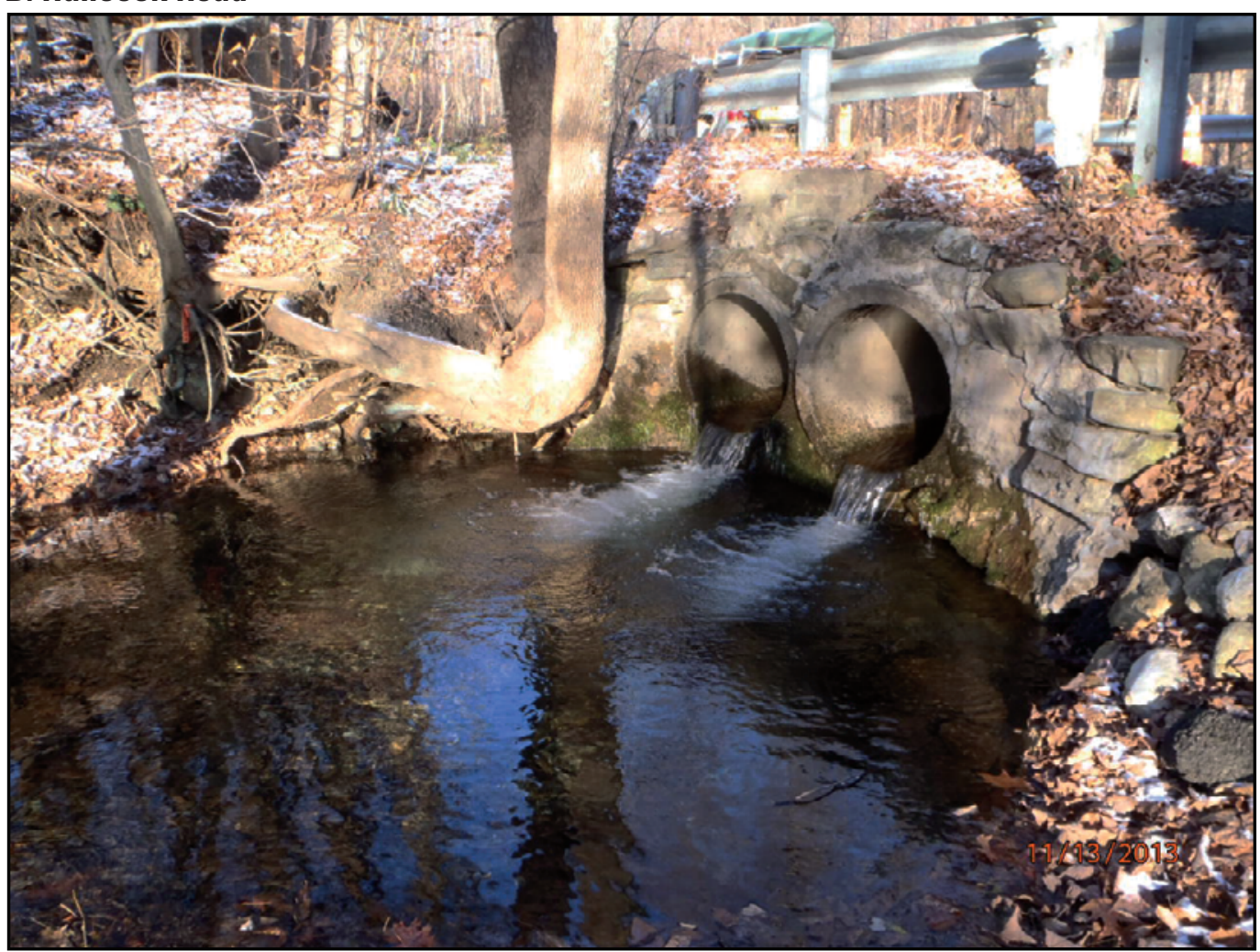

Figure 7. Downstream faces of Churchill Brook crossings in Pittsfield, Massachusetts at $A$, Churchill Street, and $B$, Hancock Road. 
AOP structure than would otherwise be possible. The multiple opening analysis option in HEC-RAS was used to partition flow between the culvert and road overflow at the culvert from flow over the low lying road to the east. Flow over the low road opening was constricted in the HEC-RAS model by use of fictitious obstructions to limit the amount of flow over the road to the east of the stream crossing. In the final model, about 30 to 45 percent of the flow passes through the multiple openings representing the low road to the east of the structure at the 2- to 0.2-percent AEP flow, respectively (both EMA and TR-55-NERCC flows). Weir flow at the culverts accounts for about 30 to 80 percent of the 2- to 0.2 -percent AEP flows, respectively. Flow through the culverts accounts for 100 percent of the flow at the 10-percent AEP to about 10 percent of the flow at the 0.2-percent AEP.

Churchill Brook flows into Lake Onota (fig. 1), which is about 1,670 ft downstream from Hancock Road. The Churchill Brook reach downstream boundary was set to the elevation of Onota Lake that is controlled by crest of the lake dam rounded up to the nearest half foot $(1,078.5 \mathrm{ft})$. Periodic lake level records made during 2006-11 (Jane Winn, Berkshire Environmental Action Team (BEAT), written commun., 2013) indicate that normal lake levels are near the crest of the dam, except when the level is dropped during the non-recreational season to control near-shore aquatic weeds.

\section{Hydraulic Assessment of Existing and Alternative Stream Crossings}

The hydraulic effects of existing and alternative structures that incorporate AOP standards are compared at seven sites in Massachusetts. The alternative structures at all sites except Churchill Brook are considered to be examples of plausible AOP structures that could be used to replace existing structures, but other designs that meet AOP standards tailored to local interests, cost, and other considerations could affect the final design of a replacement structure. Alternative structures crossing Churchill Brook are already in the design phase and were used in the analysis. Characteristics of existing and alternative structures for all sites are summarized in table 4. Steady-state flow through the structures generally was

Table 4. Characteristics of the existing and simulated alternative stream-crossing structures in Massachusetts.

[ft, feet; $\mathrm{ft}^{2}$, square feet]

\begin{tabular}{|c|c|c|c|c|c|c|c|}
\hline River & Road crossing & Structure & $\begin{array}{c}\text { Width } \\
\text { (ft) }\end{array}$ & $\begin{array}{l}\text { Height } \\
\text { (ft) }\end{array}$ & $\begin{array}{c}\text { Length } \\
\text { (ft) }\end{array}$ & $\begin{array}{c}\text { Total area }{ }^{1} \\
\quad\left(\mathrm{ft}^{2}\right)\end{array}$ & $\begin{array}{c}\text { Openness } \\
\text { ratio }^{2} \\
\text { (ft) }\end{array}$ \\
\hline \multicolumn{8}{|c|}{ Existing structures } \\
\hline Mill Brook & Church Street (Route 62) & Fieldstone box culvert & 6 & 3.5 & 50 & 21.0 & 0.42 \\
\hline Nashoba Brook & Main Street (Route 27) & 2 corrugated metal culverts & 6 & 6 & 40 & 56.5 & 0.71 \\
\hline Wading River & Richardson Avenue & 3 corrugated metal culverts & 5 & 5 & 40 & 58.9 & 0.49 \\
\hline Segreganset River & Glebe Street & Fieldstone box culvert & 4 & 4 & 40 & 16.0 & 0.40 \\
\hline Churchill Brook & Churchill Street & Corrugated metal culvert ${ }^{3}$ & 4 & 4 & 47 & 8.6 & 0.18 \\
\hline Churchill Brook & Hancock Road & 2 concrete culverts & 2.5 & 2.5 & 30 & 9.8 & 0.16 \\
\hline \multicolumn{8}{|c|}{ Alternative structures } \\
\hline Sevenmile River & Read Street & Bridge & 30 & 8 & 29 & 247 & 8.5 \\
\hline Segreganset River & Glebe Street & Bridge & 14 & 7 & 40 & 83.0 & 2.1 \\
\hline Churchill Brook & Churchill Street & Bridge & 18 & 7 & 32 & 109 & 3.4 \\
\hline Churchill Brook & Hancock Road & Bridge & 18 & 4 & 32 & 55.0 & 1.7 \\
\hline
\end{tabular}

${ }^{1}$ Total area refers to the stream crossing open area; a multi-barrel structure is the sum of the barrel areas.

${ }^{2}$ The openness ratio refers to the cross-sectional area divided by length; multi-barrel structure openness is determined from the area of the largest single barrel.

${ }^{3}$ Culvert is partially collapsed at the downstream end, and the upstream end is faced with fieldstone about $4 \mathrm{ft}$ wide by $3 \mathrm{ft}$ high. The total area and openness ratio reflect the collapsed downstream open area that was simulated with a diameter of $3.3 \mathrm{ft}$. 
simulated for 20-, 10-, 2-, 1-, and 0.2-percent AEP flood flows; however, 20- and 0.2-percent AEP flows were not available for some sites. The assessment also includes the extent to which the existing and alternative structures meet AOP standards.

\section{Mill Brook at Church Street (Route 62) in Wilmington}

Mill Brook in northeastern Massachusetts (fig. 1) is crossed by Church Street (Route 62) in Wilmington. Mill Brook is in the headwaters of the Ipswich River and has a drainage area of $2.22 \mathrm{mi}^{2}$ at Church Street. During the field survey at relatively low flow, the water level in the culvert was shallow (approximately $0.25 \mathrm{ft}$ ), and the open-bottom structure probably would allow passage of aquatic organisms given sufficient streamflow. However, the low culvert height $(3.5 \mathrm{ft})$ and openness ratio $(0.42 \mathrm{ft})$ likely deter passage of most nonaquatic wildlife. Church Street also appreciably constricts the natural channel as indicated by the upstream face cross section in figure $8 \mathrm{~A}$.
Hydraulically, the existing culvert causes appreciable backwater (a large drop in water elevation from the upstream to the downstream ends of the culvert) at the 2-percent AEP flows and greater (fig. 9A). Road overflow occurs at the 2- and 1-percent AEP simulated flows determined by the Massachusetts regional equations (MAeq); the depth of water over the road was 0.1 and $0.3 \mathrm{ft}$, respectively. Road overflow at the 2- to 0.2-AEP flows simulated with TR-55 using NERCC rainfall was more substantial, ranging from about 0.6 to $1.8 \mathrm{ft}$, respectively. Assuming the culvert is not affected by debris, the simulated WSE profiles indicate that road overflow occurs at about $200 \mathrm{ft}^{3} / \mathrm{s}$ (fig. 9A). Simulations also indicate the WSE is affected by the low gradient downstream from the crossing and the downstream boundary.

The channel constriction caused by the existing structure is also made evident by about a 2 - to 3 -fold increase in the stream velocity through the culvert relative to the stream velocity at the approach and exit cross sections for a 10-percent AEP flow (table 5). At the 1-percent AEP flow, the velocity through the culvert is more pronounced, about $9 \mathrm{ft} / \mathrm{s}$.

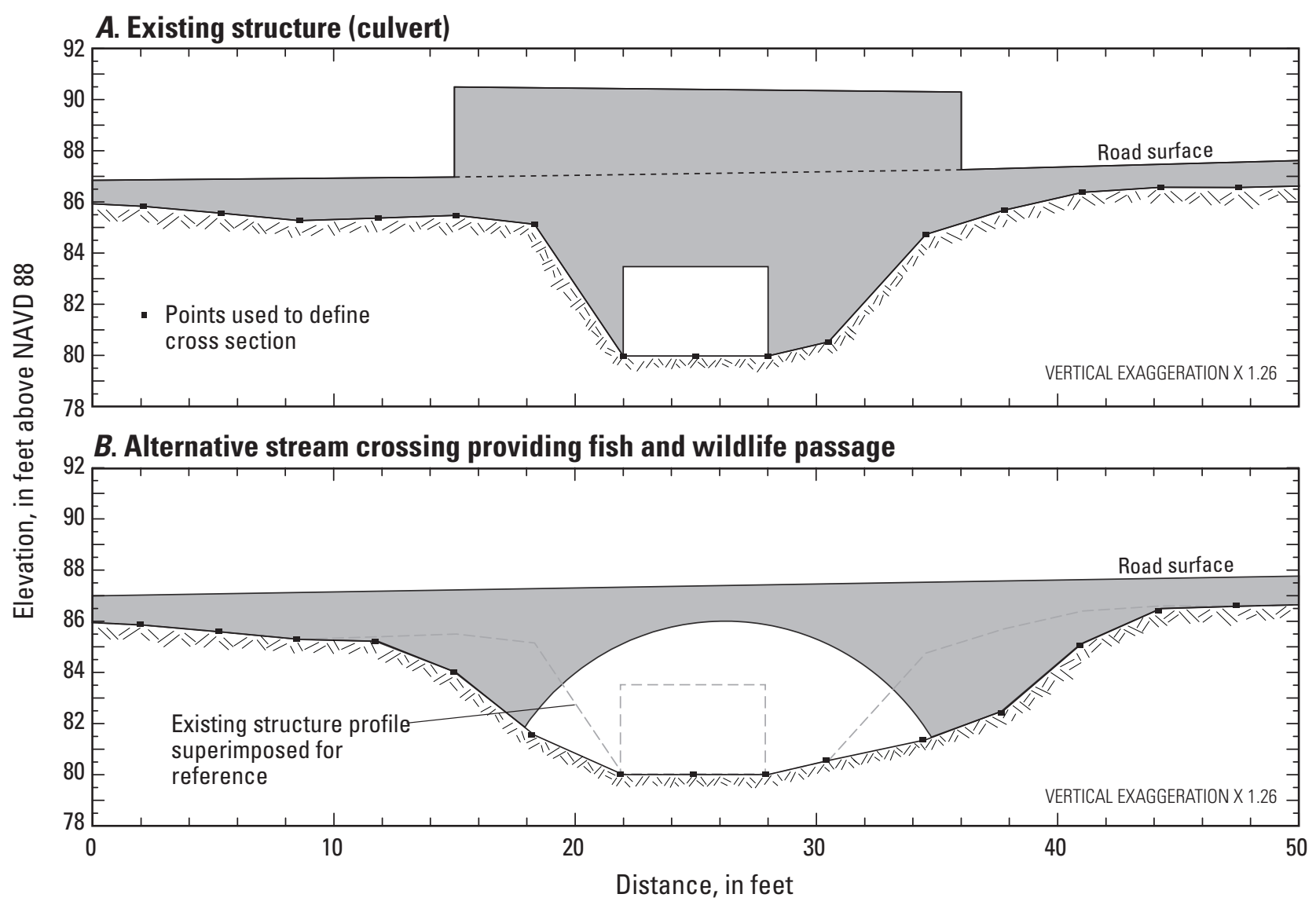

Figure 8. Upstream face cross section of Church Street (Route 62) at Mill Brook in Wilmington, Massachusetts: $A$, existing structure, and $B$, alternative stream crossing providing fish and wildlife passage. 


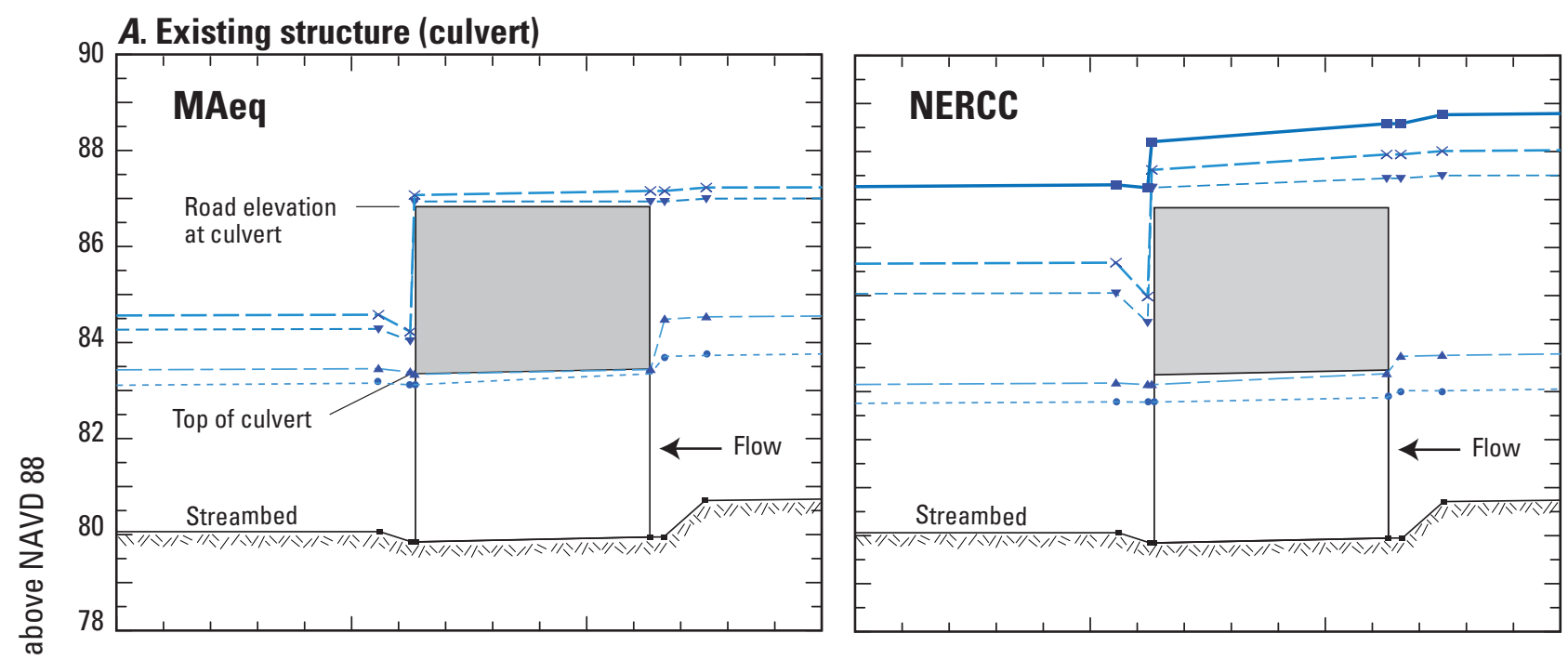

B. Alternative stream crossing providing fish and wildlife passage

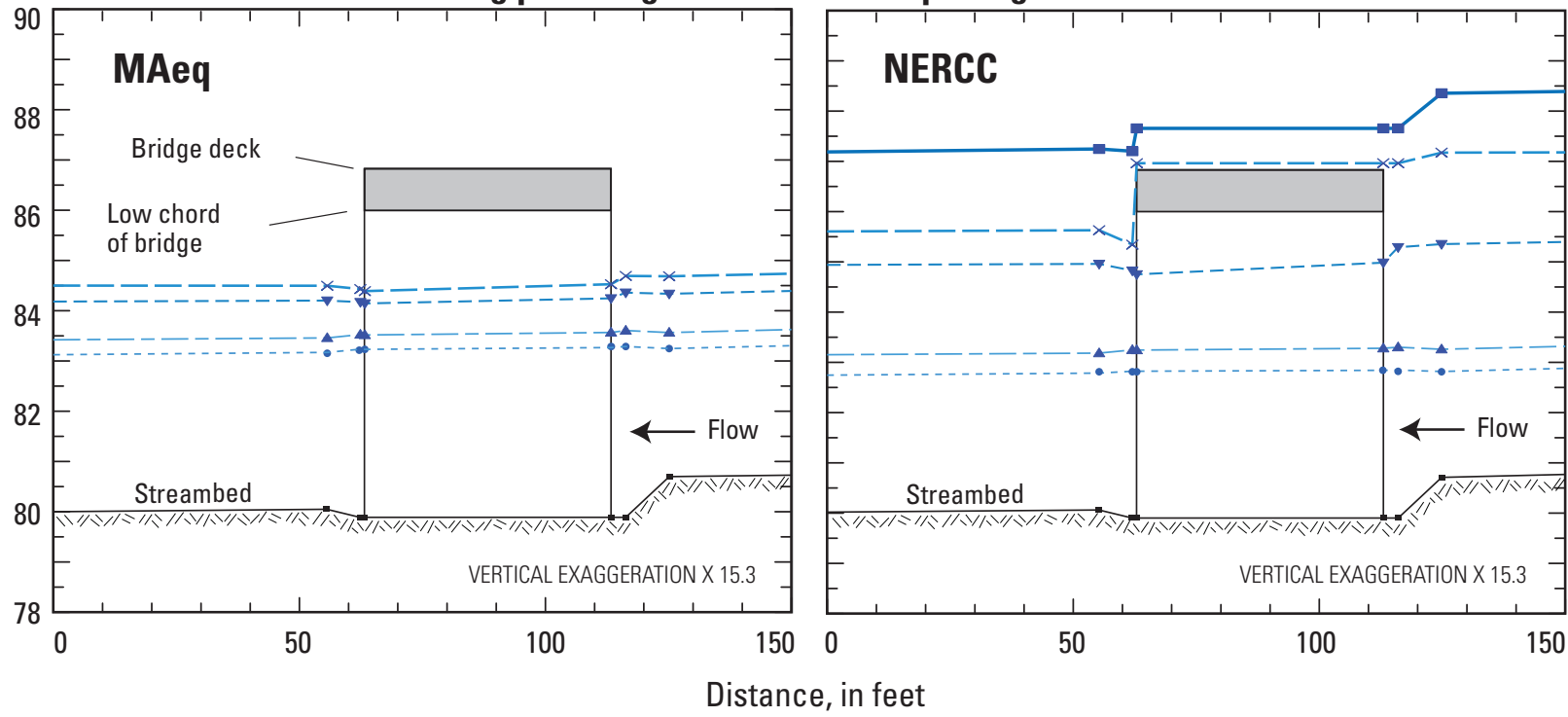

EXPLANATION

Water-surface elevations for annual exceedance probability (AEP) flood flows from $\left(\%\right.$, percent; $\mathrm{ft}^{3} / \mathrm{s}$, cubic feet per second)

Massachusetts regional equations ${ }^{1}$ (MAeq)

\begin{tabular}{|c|c|}
\hline AEP & Flow \\
\hline$-*-1 \%$ & $240 \mathrm{ft}^{3} / \mathrm{s}$ \\
\hline$--\nvdash-\quad 2 \%$ & $200 \mathrm{ft}^{3} / \mathrm{s}$ \\
\hline$-10 \%$ & $120 \mathrm{ft}^{3} / \mathrm{s}$ \\
\hline ... $20 \%$ & $90 \mathrm{ft}^{3} /$ \\
\hline
\end{tabular}

Symbols represent simulated points in model cross sections
TR-55 NERCC² (NERCC)

\begin{tabular}{|c|c|c|}
\hline & AEP & Flow \\
\hline$\longrightarrow$ & $0.2 \%$ & $1,160 \mathrm{ft}^{3} / \mathrm{s}$ \\
\hline$-*-$ & $1 \%$ & $490 \mathrm{ft}^{3} / \mathrm{s}$ \\
\hline$-k-$ & $2 \%$ & $320 \mathrm{ft}^{3} / \mathrm{s}$ \\
\hline & $10 \%$ & $90 \mathrm{ft}^{3} / \mathrm{s}$ \\
\hline 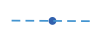 & $20 \%$ & $50 \mathrm{ft}^{3} / \mathrm{s}$ \\
\hline
\end{tabular}

${ }^{1}$ Regional regression equations for estimating flood flows in Massachusetts (Wandle, 1983)

${ }^{2}$ Rainfall-runoff model TR-55 and Northeast Regional Climate Center (NERCC) extreme precipitation (DeGaetano and Zarrow, undated)

Figure 9. Simulated Mill Brook water-surface elevation profiles at Church Street (Route 62) in Wilmington, Massachusetts: $A$, existing structure, and $B$, alternative stream crossing providing fish and wildlife passage. 
Table 5. Hydraulic characteristics of simulated structures at the 10- and 1-percent annual exceedance probability flow for Mill Brook at Church Street (Route 62) in Wilmington, Massachusetts.

[AEP, annual exceedance probability; W.S., water surface; ft, feet; ft/s, feet per second; $\mathrm{ft}^{3} / \mathrm{s}$, cubic feet per second; US, upstream; DS, downstream. Flows were determined with Massachusetts regional flood-flow equations (Wandle, 1983)]

\begin{tabular}{|c|c|c|c|c|c|}
\hline \multicolumn{2}{|c|}{ Model station } & \multicolumn{2}{|c|}{ Existing structure } & \multicolumn{2}{|c|}{ Alternative structure } \\
\hline Number & Description & $\begin{array}{l}\text { W.S. elevation } \\
\text { (ft) }\end{array}$ & $\begin{array}{c}\text { Stream velocity } \\
(\mathrm{ft} / \mathrm{s})\end{array}$ & $\begin{array}{l}\text { W.S. elevation } \\
\text { (ft) }\end{array}$ & $\begin{array}{c}\text { Stream velocity } \\
(\mathrm{ft} / \mathrm{s})\end{array}$ \\
\hline \multicolumn{6}{|c|}{10 -percent AEP $\left(120 \mathrm{ft}^{3} / \mathrm{s}\right)$} \\
\hline 1,287 & Approach & 84.54 & 2.0 & 83.57 & 3.3 \\
\hline 1,278 & US face & 84.50 & 2.6 & 83.61 & 2.6 \\
\hline \multirow[t]{2}{*}{1,249} & US culvert/bridge $^{1}$ & 84.50 & 5.7 & 83.57 & 2.8 \\
\hline & DS culvert/bridge ${ }^{1}$ & 84.50 & 5.7 & 83.52 & 2.8 \\
\hline 1,224 & DS face & 83.40 & 4.5 & 83.53 & 2.7 \\
\hline 1,218 & Exit & 83.47 & 3.1 & 83.46 & 3.1 \\
\hline \multicolumn{6}{|c|}{ 1-percent AEP $\left(240 \mathrm{ft}^{3} / \mathrm{s}\right)$} \\
\hline 1,287 & Approach & 87.23 & 1.2 & 84.69 & 3.8 \\
\hline 1,278 & US face & 87.16 & 2.4 & 84.69 & 3.7 \\
\hline \multirow[t]{2}{*}{1,249} & US culvert/bridge $^{1}$ & 87.16 & 9.0 & 84.53 & 4.5 \\
\hline & DS culvert/bridge $^{1}$ & 87.16 & 9.0 & 84.39 & 4.6 \\
\hline 1,224 & DS face & 84.24 & 7.2 & 84.43 & 4.1 \\
\hline 1,218 & Exit & 84.59 & 2.7 & 84.50 & 2.9 \\
\hline
\end{tabular}

${ }^{1}$ Internal sections created by model.

These velocities represent flood flows that occur infrequently and are not important for normal (non-flood flow) passage of aquatic organism. However, the simulations indicate that velocities likely increase markedly under more moderate flows and would cause an impediment to aquatic organism passage. In addition to the impediment stream velocities would have on fish and wildlife, the pronounced increase in velocity in and near the culvert is a potential erosion hazard that could lead to structural failure that can be exacerbated by the susceptibility of the small opening to debris blockage.

A hypothetical arched structure (bridge or culvert) that incorporates AOP standards was simulated to replace the Church Street (Route 62) culvert (fig. 8B). Although HECRAS can simulate an arched structure as either a bridge or a culvert, the structure was simulated as a bridge because the internal bottom geometry of a bridge is interpolated from the downstream and upstream face geometry, thereby maintaining the natural channel profile, whereas a culvert would be simulated as a flat bottom.

The bankfull width was determined from seven model cross sections that varied from 10 to $32 \mathrm{ft}$ and averaged $21 \mathrm{ft}$. Excluding cross sections near the road crossing (approach, upstream and downstream faces, and exit sections), the bankfull width averaged $19 \mathrm{ft}$. The bankfull width determined by the two-parameter regional bankfull equations (14 ft) by Bent and Waite (2013) multiplied by 1.2, resulted in an AOP span of $17 \mathrm{ft}$, which was used in the AOP design. The maximum width of the arched bridge was about $16 \mathrm{ft}$ because of the upward sloping streambanks at the sides of the structure. The maximum height of the arch above the thalweg of the stream was about $6 \mathrm{ft}$ (fig. 8B). The arched bridge has a cross sectional open area of about $65 \mathrm{ft}^{2}$, which is about 3 times the area of the existing culvert $\left(21 \mathrm{ft}^{2}\right)$.

Although a larger opening height and width would be preferred, the structure was simulated to meet the general AOP standards to provide an example of a lower cost structure than one that fully meets optimum AOP criteria. The size of the arched bridge simulated in this example allows the road elevation to remain unchanged. The openness ratio of the arched bridge is about $1.3 \mathrm{ft}$, which is smaller than any of the other alternative structures developed for this study, but is 4 times the openness ratio of the existing structure and about 40 percent larger than the minimum AOP openness criterion.

Hydraulically, the simulated arched bridge is able to convey all MAeq flood flows without causing backwater upstream from the structure (fig. 9B). WSE profiles indicate road flooding ranging from about 0.1 to $0.9 \mathrm{ft}$ occurs at 1 - to 0.2-percent AEP NERCC flows, respectively. As previously 
noted for the simulation of the existing structure, the WSE profiles at the structure are affected by the low downstream gradient, which is more pronounced at higher flows. Stream velocities at the bridge at the 10-and 1-percent AEP MAeq flows increased little compared to upstream and downstream stream velocities (table 5). A bridge of similar design would not appreciably alter the natural stream velocities and, therefore, would not likely be an impediment to aquatic organism passage.

The bridge meets or exceeds the minimum AOP standards in terms of openness, opening height, and velocity, and conveys the flood flows simulated without causing road flooding or appreciable backwater upstream from the bridge, except for the highest simulated flows. The highest simulated flows have a large uncertainty given that they were determined from an uncalibrated rainfall-runoff model. Furthermore, the downstream gradient below the surveyed exit cross section is a conservative low estimate, which increases the WSE at the stream crossing. More accurate WSEs at the stream crossing would require detailed field surveys of the channel bottom farther downstream from the stream crossing to establish the stream gradient and downstream boundary condition.

\section{Nashoba Brook at Main Street (Route 27) in Acton}

Nashoba Brook in east-central Massachusetts (fig. 1) is crossed by Main Street (Route 27) about 4 mi northeast of the town center of Acton. The brook has a drainage area of $11.6 \mathrm{mi}^{2}$ at the Main Street crossing. During a recent site visit (2013), at relatively low flow, the culverts were submerged to about one-third of their height (fig. 3) and appeared to provide adequate passage for aquatic organisms but not for other wildlife. The existing structure appreciably constricts the natural channel as indicated by the upstream face profile in figure 10A. The existing structure has an openness ratio of $0.71 \mathrm{ft}$ (table 4).

Hydraulically, the existing structure causes backwater for all simulated flood flows used in the analysis (fig. 11A). WSE profiles at the 2-percent AEP for both EMAadj and FIS flows indicate that the capacities of the culverts are exceeded at the 2-percent AEP (fig. 11A), resulting in about 0.2 and $0.4 \mathrm{ft}$ of road overflow, respectively. At the 0.2-percent AEP flow, road overflow was 0.8 and $1.1 \mathrm{ft}$ for EMAadj and FIS flows, respectively.

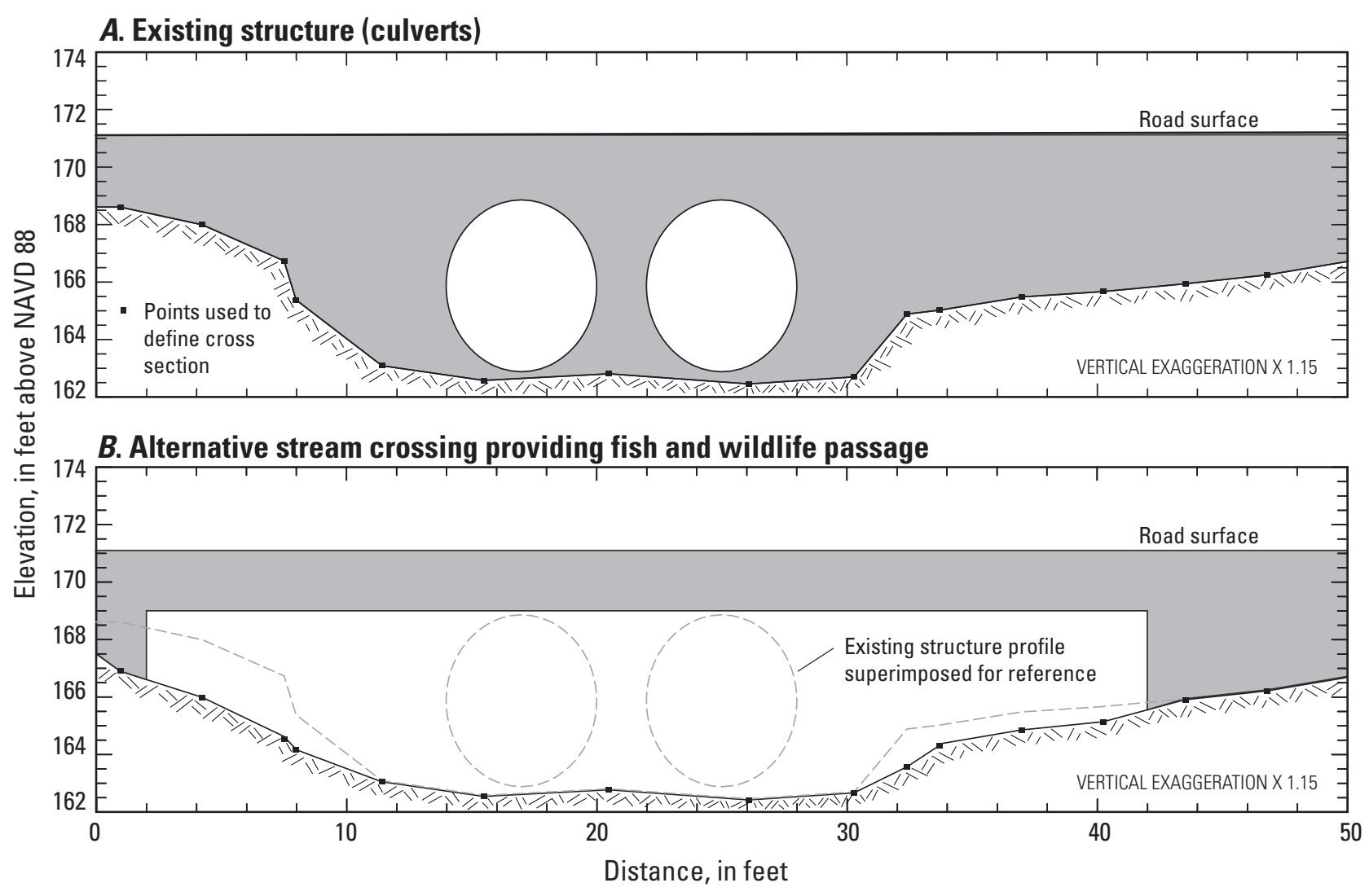

Figure 10. Upstream face cross section of Main Street (Route 27) at Nashoba Brook in Acton, Massachusetts: $A$, existing structure, and $B$, alternative stream crossing providing fish and wildlife passage. 


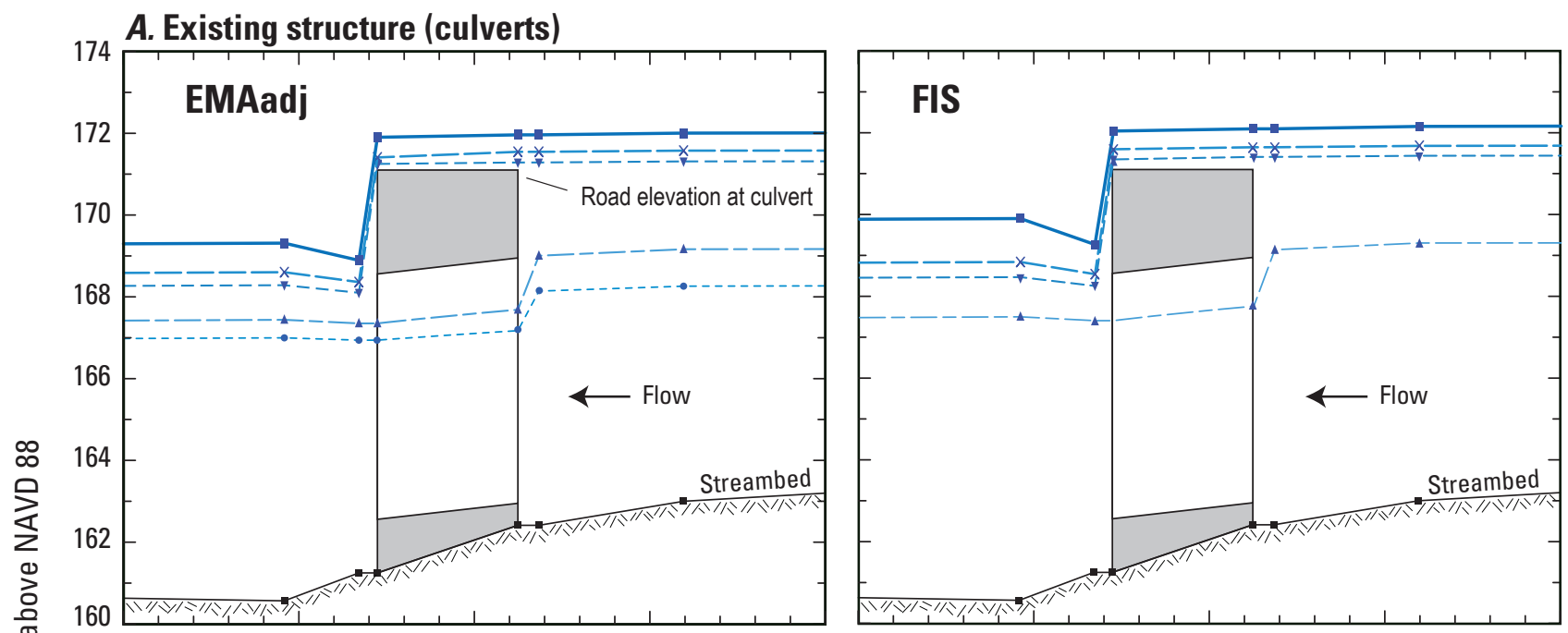

B. Alternative stream crossing providing fish and wildlife passage

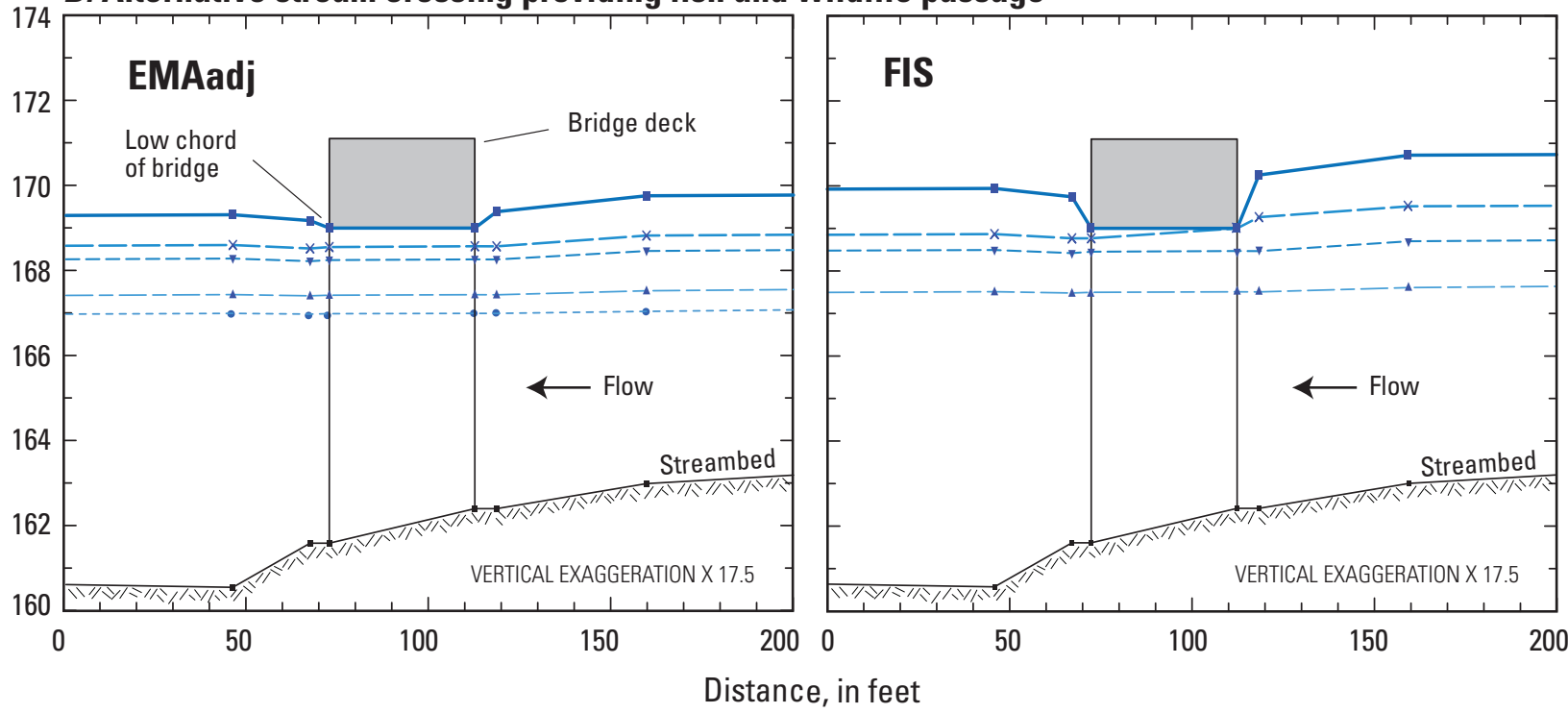

EXPLANATION

Water-surface elevations for annual exceedance probability (AEP) flood flows from $\left(\%\right.$, percent; $\mathrm{ft}^{3} / \mathrm{s}$, cubic feet per second)

EMA area adjusted ${ }^{1}$ (EMAadj)

AEP Flow

$\begin{array}{lr}-0.2 \% & 1,030 \mathrm{ft}^{3} / \mathrm{s} \\ -*- & 740 \mathrm{ft}^{3} / \mathrm{s} \\ --2 & 620 \mathrm{ft}^{3} / \mathrm{s} \\ --10 \% & 390 \mathrm{ft}^{3} / \mathrm{s} \\ --20 \% & 300 \mathrm{ft}^{3} / \mathrm{s}\end{array}$

Flood Insurance Study² (FIS)

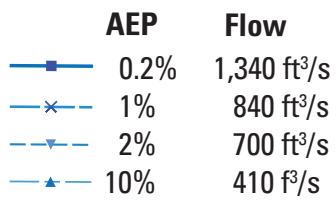

Symbols represent simulated points in model cross sections

1 Expected moments analysis (EMA) of annual peak flows at Nashoba Brook streamgage 0109730 adjusted for drainage area. ${ }^{2}$ Flood Insurance Study, Middlesex County, Massachusetts (FEMA, 2010).

Figure 11. Simulated Nashoba Brook water-surface elevation profiles at Main Street (Route 27) in Acton, Massachusetts: $A$, existing crossing, and $B$, alternative stream crossing providing fish and wildlife passage. 
The constriction of the existing structure is also evident by about a 5 -fold increase in the stream velocity through the culvert relative to the stream velocity at the approach and exit cross sections (table 6). The simulations indicate that velocities likely increase markedly under more moderate flows and are likely an impediment to aquatic organism passage. The large increase in velocity in and near the culverts is a potential erosion hazard that could lead to structural failure.

A hypothetical bridge that incorporates AOP standards was simulated to replace the existing culverts at Main Street (fig. 10B). The height of the bridge opening is approximately the same as the height of the culverts to minimize changes to the road elevation. The bridge span was determined from the bankfull widths of 4 upstream and 5 downstream model cross sections that varied from 22 to $51 \mathrm{ft}$. The average cross-section bankfull width (34 ft) was about equal to the width (33 ft) determined by the two-parameter regional bankfull equations of Bent and Waite (2013). The rounded bankfull width multiplied by 1.2 resulted in a bridge span of $40 \mathrm{ft}$, which is similar to the width of the channel cross section at the upstream face of the culverts (fig. 10B). The distance between the streambed and the low chord of the bridge is about $7 \mathrm{ft}$ at the thalweg and 2 to $3 \mathrm{ft}$ at the abutments, which is less than the optimal criterion but does not require an appreciable change in the road elevation. The bridge opening has a cross sectional area of $247 \mathrm{ft}^{2}$, which is about 4 times the combined area of the two culverts $\left(56.5 \mathrm{ft}^{2}\right)$, and an openness ratio of $6.2 \mathrm{ft}$, which is more than 8 times larger than the openness ratio of a single existing culvert.

Hydraulically, the bridge designed to meet AOP standards is able to convey all simulated flows without road overflow (fig. 11B). The bridge opening was at full capacity only at the 0.2 percent AEP for both EMAadj and FIS simulated flows but did not overflow the road. The WSE profiles indicate the upstream WSE is largely controlled by the low gradient downstream from the structure. Sensitivity tests indicate that doubling the downstream boundary gradient to 0.001 would result in about a $0.3-\mathrm{ft}$ drop in the water surface at the stream crossing. The stream velocity at the bridge at the 10-percent AEP EMAadj flow indicates little alteration in velocity compared to upstream and downstream velocities (table 6). At the 1-percent AEP EMAadj flow, stream velocities at the bridge are about twice the stream velocity in the exit channel cross sections. The simulations indicate that a bridge of similar design would not appreciably alter the natural stream velocities at more moderate flows.

Table 6. Hydraulic characteristics of simulated stream-crossing structures at the 10- and 1-percent annual exceedance probability flow for Nashoba Brook at Glebe Street in Acton, Massachusetts.

[AEP, annual exceedance probability; W.S., water surface; ft, feet; ft/s, feet per second; $\mathrm{ft}^{3} / \mathrm{s}$, cubic feet per second; US, upstream; DS, downstream. Flows determined by expected moments analysis of annual peak flows at Nashoba Brook at Acton (01097300) and adjusted for drainage area]

\begin{tabular}{|c|c|c|c|c|c|}
\hline \multicolumn{2}{|c|}{ Model station } & \multicolumn{2}{|c|}{ Existing structure } & \multicolumn{2}{|c|}{ Alternative structure } \\
\hline Number & Description & $\begin{array}{l}\text { W.S. elevation } \\
\text { (ft) }\end{array}$ & $\begin{array}{c}\text { Stream velocity } \\
(\mathrm{ft} / \mathrm{s})\end{array}$ & $\begin{array}{l}\text { W.S. elevation } \\
\text { (ft) }\end{array}$ & $\begin{array}{c}\text { Stream velocity } \\
(\mathrm{ft} / \mathrm{s})\end{array}$ \\
\hline \multicolumn{6}{|c|}{ 10-percent AEP $\left(390 \mathrm{ft}^{3} / \mathrm{s}\right)$} \\
\hline 1,027 & Approach & 169.16 & 1.4 & 167.51 & 2.8 \\
\hline 985 & US face & 169.00 & 3.1 & 167.42 & 2.9 \\
\hline \multirow[t]{2}{*}{961} & US culvert/bridge $^{1}$ & 169.00 & 8.5 & 167.42 & 2.8 \\
\hline & DS culvert/bridge ${ }^{1}$ & 169.00 & 8.0 & 167.41 & 2.6 \\
\hline 934 & DS face & 167.33 & 3.8 & 167.39 & 2.6 \\
\hline 913 & Exit & 167.42 & 1.7 & 167.42 & 1.7 \\
\hline \multicolumn{6}{|c|}{ 1-percent AEP $\left(740 \mathrm{ft}^{3} / \mathrm{s}\right)$} \\
\hline 1,027 & Approach & 171.97 & 2.0 & 168.83 & 3.0 \\
\hline 985 & US face & 171.93 & 2.4 & 168.58 & 4.2 \\
\hline \multirow[t]{2}{*}{961} & US culvert/bridge $^{1}$ & 171.56 & 11 & 168.58 & 4.1 \\
\hline & DS culvert/bridge ${ }^{1}$ & 171.56 & 11 & 168.57 & 3.8 \\
\hline 934 & DS face & 168.98 & 7.6 & 168.53 & 3.9 \\
\hline 913 & Exit & 169.39 & 2.3 & 168.61 & 2.1 \\
\hline
\end{tabular}

${ }^{1}$ Internal sections created by model; internal culvert velocity is the average of the two culverts. 
The simulated bridge meets or exceeds AOP standards in terms of openness, opening height, and velocity, although the opening height is less than optimal to minimize changes to the road elevation. All simulated flood flows were conveyed past the bridge without causing road flooding or appreciable backwater upstream from the bridge. However, the simulations indicate little tolerance for flood flows above the upper estimate without causing road flooding. The simulations were made using a conservative estimate of the downstream gradient which strongly affects the WSE at the Main Street. Detailed field surveys of the channel bottom for a sufficient distance downstream from the stream crossing would be required to establish the actual downstream gradient.

\section{Wading River at Richardson Avenue in Norton}

The Wading River in southeastern Massachusetts (fig. 1) is crossed by Richardson Avenue in the northwestern corner of Norton. The drainage area upstream from Richardson Avenue is $21.5 \mathrm{mi}^{2}$, which is approximately half the drainage area at the USGS Wading River streamgage (01109000). The culverts are partially submerged at relatively low flow and appear to provide adequate passage for aquatic organisms but not for other wildlife. The existing structure appreciably constricts the natural channel cross section as indicated by upstream face cross section in figure 12A. The existing structure has an openness ratio of $0.49 \mathrm{ft}$.

Hydraulically, the existing structure causes backwater for all simulated flows (fig. 13A). The capacities of the culverts are exceeded at the 2-percent AEP flow and higher, based on simulated WSEs determined from the Wading River streamgage EMA analysis adjusted for drainage area (EMAadj), and 10-percent AEP flows and higher determined from the Rhode Island regional equations (RIeq). Road overflow depths ranged from about 0.3 to $0.9 \mathrm{ft}$ for 2 - to 0.2-percent AEP EMAadj flows, respectively, and from about 0.1 to $1.4 \mathrm{ft}$ for 10 - to 0.2 -percent AEP RIeq flows, respectively. The downstream WSE was sufficiently below the top of the culverts and had little effect on the WSE upstream from the culvert.

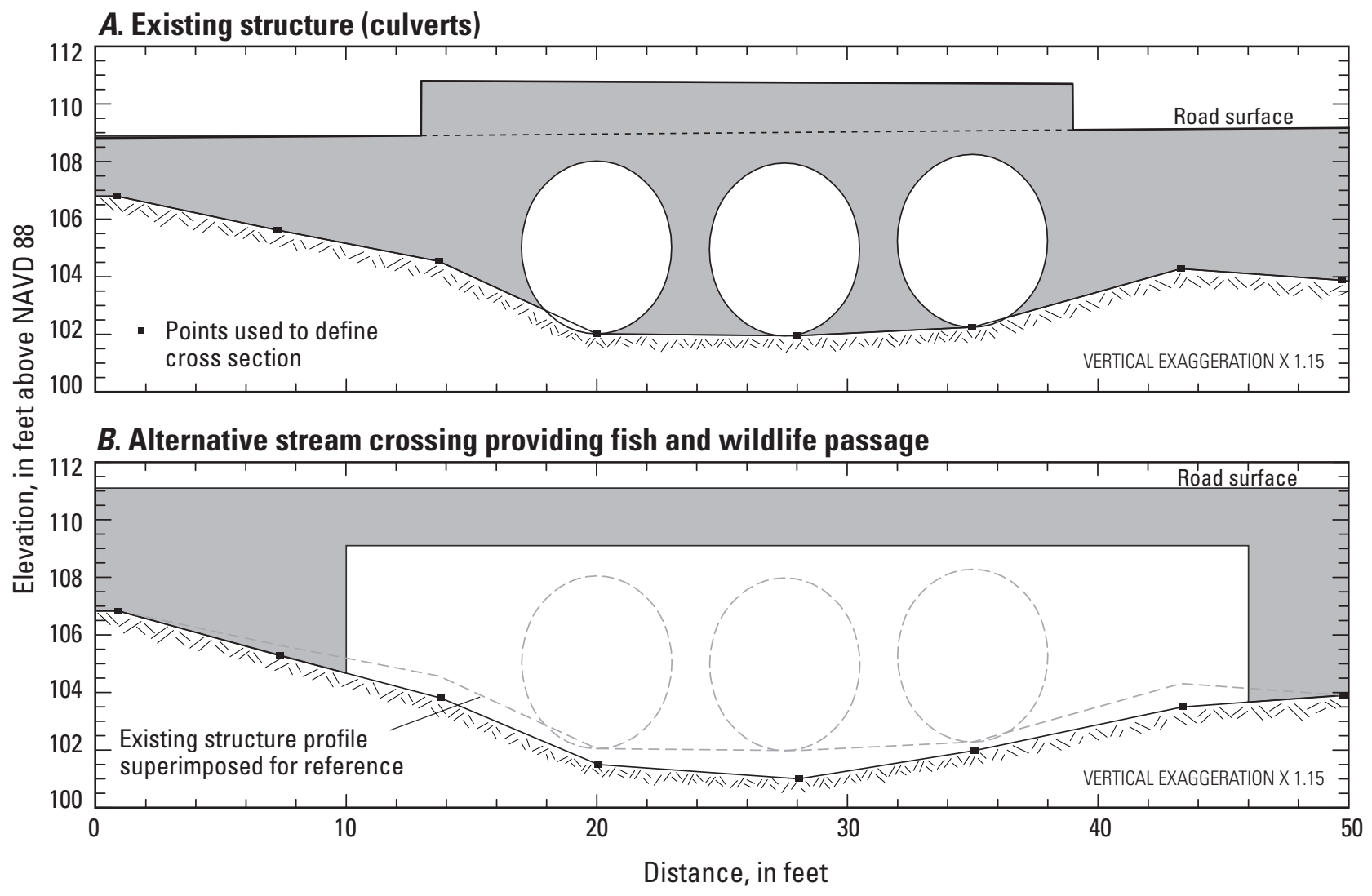

Figure 12. Upstream face cross section of Richardson Avenue at Wading River in Norton, Massachusetts: $A$, existing structure, and $B$, alternative stream crossing providing fish and wildlife passage. 


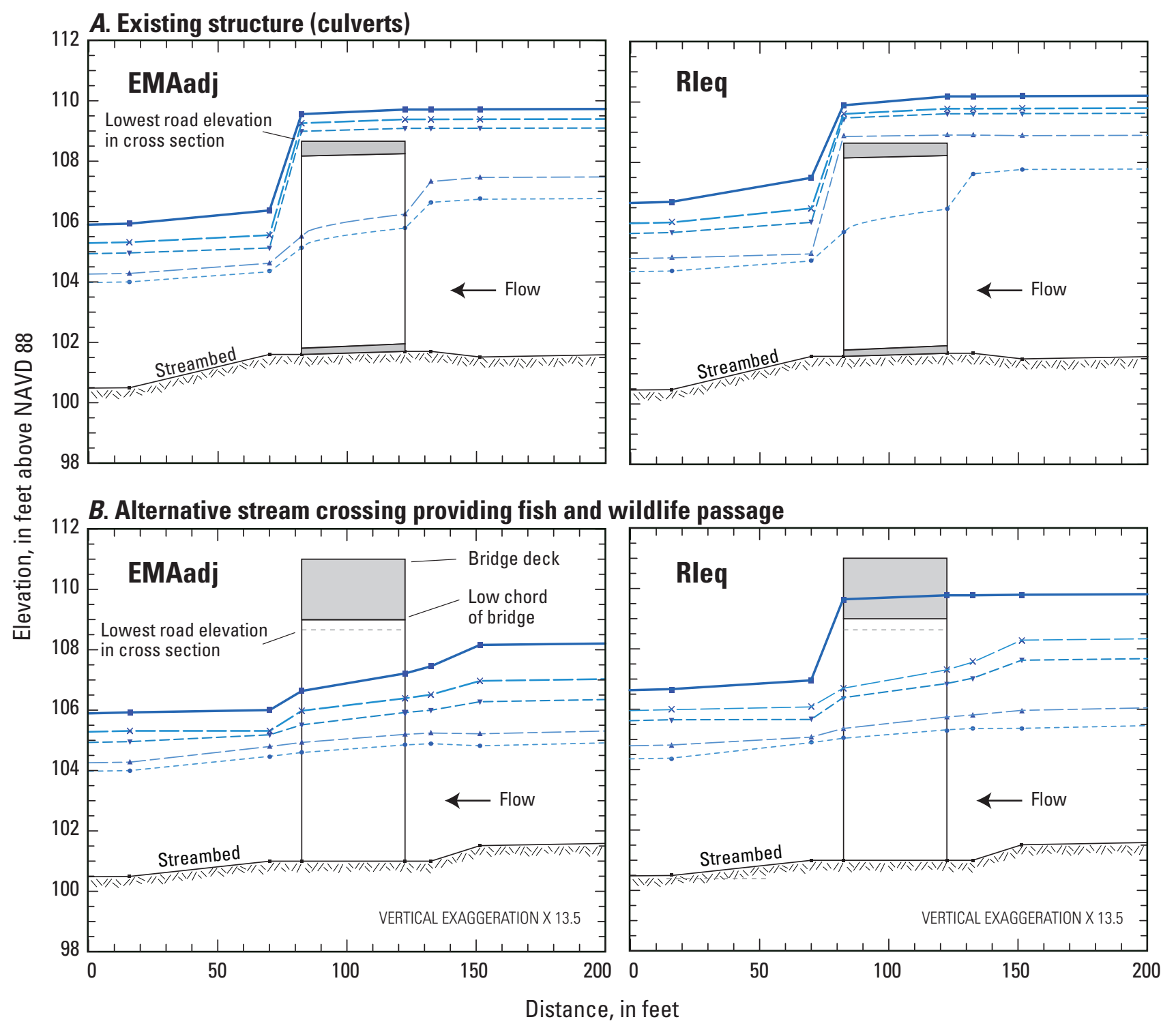

EXPLANATION

Water-surface elevations for annual exceedance probability (AEP) flood flows from $\left(\%\right.$, percent; $\mathrm{ft}^{3} / \mathrm{s}$, cubic feet per second)

\begin{tabular}{|c|c|c|}
\hline EMA are & a adju & sted $^{1}$ (EMA \\
\hline & AEP & Flow \\
\hline$\longrightarrow$ & $0.2 \%$ & $1,350 \mathrm{ft}^{3} / \mathrm{s}$ \\
\hline$-*-$ & $1 \%$ & $970 \mathrm{ft}^{3} / \mathrm{s}$ \\
\hline$-\rightarrow--$ & $2 \%$ & $780 \mathrm{ft}^{3} / \mathrm{s}$ \\
\hline$-\leftarrow-$ & $10 \%$ & $510 \mathrm{ft}^{3} / \mathrm{s}$ \\
\hline$-\ldots$ & $20 \%$ & $410 \mathrm{ft}^{3} / \mathrm{s}$ \\
\hline
\end{tabular}

${ }^{1}$ Expected moments analysis (EMA) of annual peak flows at Wading River streamgage 01109000 weighted with Rhode Island regional flood-flow equations and adjusted for drainage area.

${ }^{2}$ Regional flood-flow equations for Rhode Island and surrounding areas (Zarriello and others, 2012).
Rhode Island regional equations ${ }^{2}$ (Rleq)

$\begin{array}{ccc} & \text { AEP } & \text { Flow } \\ -- & 0.2 \% & 1,950 \mathrm{ft}^{3} / \mathrm{s} \\ -*- & 1 \% & 1,400 \mathrm{ft}^{3} / \mathrm{s} \\ --- & 2 \% & 1,170 \mathrm{ft}^{3} / \mathrm{s} \\ -\leftarrow-10 \% & 720 \mathrm{ft}^{3} / \mathrm{s} \\ --- & 20 \% & 550 \mathrm{ft}^{3} / \mathrm{s}\end{array}$

Symbols represent simulated points in model cross sections

Figure 13. Simulated Wading River water-surface elevation profiles at Richardson Avenue in Norton, Massachusetts: $A$, existing structure, and $B$, alternative stream crossing providing fish and wildlife passage. 
The channel constriction from the existing structure is also evident by about a 3- to 6-fold increase in the stream velocity through the culvert relative to the stream velocity at the approach for the 10- and 1-percent AEP EMAadj flow (table 7), indicating the approach velocities were appreciably dampened by backwater caused by the structure. The average culvert velocity was about 30 to 50 percent greater than the exit cross section velocity for the 10- and 1-percent AEP EMAadj flow, respectively. The simulations indicate that velocities likely increase markedly under more moderate flows and are an impediment to aquatic organism passage. The large increase in stream velocity at the existing structure also indicates a potential erosion hazard.

A hypothetical bridge that incorporates optimal AOP standards was simulated to replace the existing culverts at Richardson Avenue (fig. 12B). The bridge span was determined from the bankfull width from 2 upstream and 4 downstream model cross sections that varied from 26 to $36 \mathrm{ft}$ (two cross sections with anomalously large bankfull widths were not used). The average bankfull width (38 ft) was about equal to the width $(40 \mathrm{ft})$ determined by the twoparameter regional bankfull equations of Bent and Waite (2013). The rounded bankfull width multiplied by 1.2 resulted in a bridge span of $46 \mathrm{ft}$, which is similar to the width of channel cross section at the upstream face of the culvert (fig. 12B). The distance between the streambed and the low chord of the bridge is about $8 \mathrm{ft}$ at the thalweg and $5 \mathrm{ft}$ at the abutments. Achieving the optimal bridge opening height of $8 \mathrm{ft}$ (from the thalweg to the low chord) requires the existing road elevation near the bridge be raised by about $2 \mathrm{ft}$. The opening of the bridge has a cross sectional area of about $240 \mathrm{ft}^{2}$, which is about 4.1 times the combined area of the three existing culverts $\left(58.9 \mathrm{ft}^{2}\right)$, and an openness ratio of about $6 \mathrm{ft}$, which is more than 12 times larger than the openness ratio of a single existing culvert (table 4).

Hydraulically, the bridge conveys all simulated flood flows without causing road overflow and is below the full capacity for all simulated flows except the 0.2-percent AEP RIeq flow (fig. 13B). A bridge of similar design would increase flood resiliency given the uncertainty associated with the magnitude of large floods and the possibility of future increases in flood flows. Stream velocity at the bridge at the 10-percent AEP EMAadj flow indicates little alteration compared to upstream and downstream velocities (table 7). At the 1-percent AEP EMAadj flow, stream velocities at the bridge show about a 40 percent increase relative to the approach velocity, but the structure likely would not appreciably alter stream velocities at more moderate flows. The bridge meets or exceeds AOP standards in terms of openness, opening height, and velocity and conveys the simulated flood flows without causing road flooding or appreciable backwater upstream from the bridge.

Table 7. Hydraulic characteristics of simulated structures at the 10- and 1-percent annual exceedance probability flow for Wading River at Richardson Avenue in Norton, Massachusetts.

[AEP, annual exceedance probability; W.S., water surface; $\mathrm{ft}$, feet; $\mathrm{ft} / \mathrm{s}$, feet per second; $\mathrm{ft}^{3} / \mathrm{s}$, cubic feet per second; US, upstream; DS, downstream; --, not determined. Flows determined by expected moments analysis of annual peak flows at Wading River at Norton (011090000) and adjusted for drainage area]

\begin{tabular}{|c|c|c|c|c|c|}
\hline \multicolumn{2}{|c|}{ Model station } & \multicolumn{2}{|c|}{ Existing structure } & \multicolumn{2}{|c|}{ Alternative structure } \\
\hline Number & Description & $\begin{array}{l}\text { W.S. elevation } \\
\text { (ft) }\end{array}$ & $\begin{array}{c}\text { Stream velocity } \\
(\mathrm{ft} / \mathrm{s})\end{array}$ & $\begin{array}{l}\text { W.S. elevation } \\
\text { (ft) }\end{array}$ & $\begin{array}{c}\text { Stream velocity } \\
(\mathrm{ft} / \mathrm{s})\end{array}$ \\
\hline \multicolumn{6}{|c|}{10 -percent AEP $\left(510 \mathrm{ft}^{3} / \mathrm{s}\right)$} \\
\hline 40,668 & Approach & 107.46 & 2.4 & 105.22 & 6.2 \\
\hline 40,649 & US face & 107.33 & 3.4 & 105.25 & 5.2 \\
\hline \multirow[t]{2}{*}{40,630} & US culvert/bridge ${ }^{1}$ & 107.33 & 8.1 & 105.20 & 5.2 \\
\hline & DS culvert/bridge ${ }^{1}$ & -- & 9.7 & 104.94 & 5.7 \\
\hline 40,586 & DS face & 104.62 & 7.6 & 104.80 & 6.0 \\
\hline 40,532 & Exit & 104.27 & 6.9 & 104.28 & 6.9 \\
\hline \multicolumn{6}{|c|}{ 1-percent AEP (970 ft³/s) } \\
\hline 40,668 & Approach & 109.39 & 1.8 & 106.97 & 5.3 \\
\hline 40,649 & US face & 109.38 & 1.8 & 106.52 & 6.8 \\
\hline \multirow[t]{2}{*}{40,630} & US culvert/bridge ${ }^{1}$ & 109.38 & 9.8 & 106.40 & 7.0 \\
\hline & DS culvert/bridge ${ }^{1}$ & -- & 12 & 105.98 & 7.8 \\
\hline 40,586 & DS face & 105.55 & 10 & 105.32 & 9.5 \\
\hline 40,532 & Exit & 105.32 & 7.2 & 105.32 & 7.2 \\
\hline
\end{tabular}

${ }^{1}$ Internal sections created by model; upstream and downstream culvert velocity averaged from three culverts. 


\section{Sevenmile River at Read Street in Attleboro}

The Sevenmile River in southeastern Massachusetts (fig. 1) is crossed by Read Street about 3 miles west of downtown Attleboro. The river has a drainage area of $7.28 \mathrm{mi}^{2}$ at Read Street. During a site visit (2013) at relatively low flow, the culverts were partially submerged and appeared to provide adequate passage for aquatic organisms but not for other wildlife. The existing structure appreciably constricts the natural channel cross section, as indicated by the upstream face profile shown in figure 14A. The openness ratio of the existing structure is $0.68 \mathrm{ft}$, which is less than the minimum recommended openness ratio of $0.82 \mathrm{ft}$.

Hydraulically, the existing structure caused backwater for all simulated flows (fig. 15A) but most prominently for flows larger than a 10-percent AEP magnitude. At 2-, 1-, and 0.2-percent AEP flows, the culverts are at full capacity, and road overflow occurs mostly on the left side of the road crossing (fig. 15A). The extent of the channel constriction by the existing structure is also evident by the sharp increase in stream velocity through the culverts (table 8 ). At the 10 - and 1-percent AEP RIeq flows, velocities in the culverts are about twice the exit velocity. The simulations indicate that velocities likely increase markedly under more moderate flows and are an impediment to aquatic organism passage.

A hypothetical bridge that incorporates optimal AOP standards was simulated to replace the Read Street culverts (fig. 14B). The bridge span was determined from the bankfull width computed from three upstream and two downstream model cross sections that varied from 17 to $32 \mathrm{ft}$. The average cross-section bankfull width $(25.8 \mathrm{ft})$ was about equal to the width $(25.3 \mathrm{ft})$ computed by the two-parameter (drainage area and mean slope) regional bankfull equations developed by Bent and Waite (2013). The rounded bankfull width (25 ft) multiplied by 1.2 resulted in a bridge span of $30 \mathrm{ft}$, which is similar to the width of the channel cross section at the upstream face of the existing culverts (fig. 14B). The channel bottom was lowered slightly to maintain a smooth streambed gradient (fig. 15B). The distance between the streambed and the low chord of the bridge is about $8 \mathrm{ft}$ at the thalweg and $2 \mathrm{ft}$ at the abutments, which requires the road be raised about $2 \mathrm{ft}$

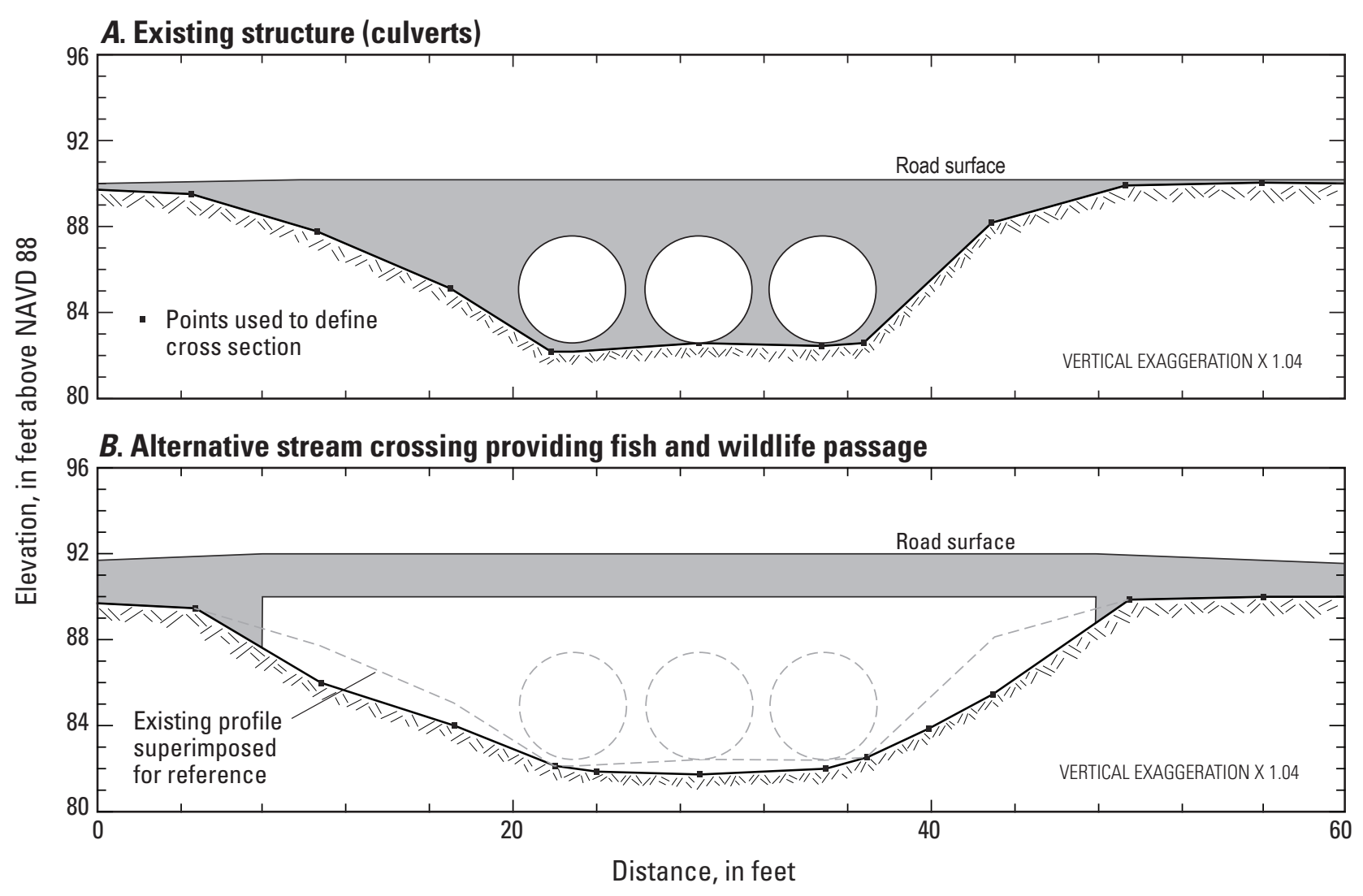

Figure 14. Upstream face cross section of Read Street at Sevenmile River in Attleboro, Massachusetts: $A$, existing structure, and $B$, alternative stream crossing providing fish and wildlife passage. 


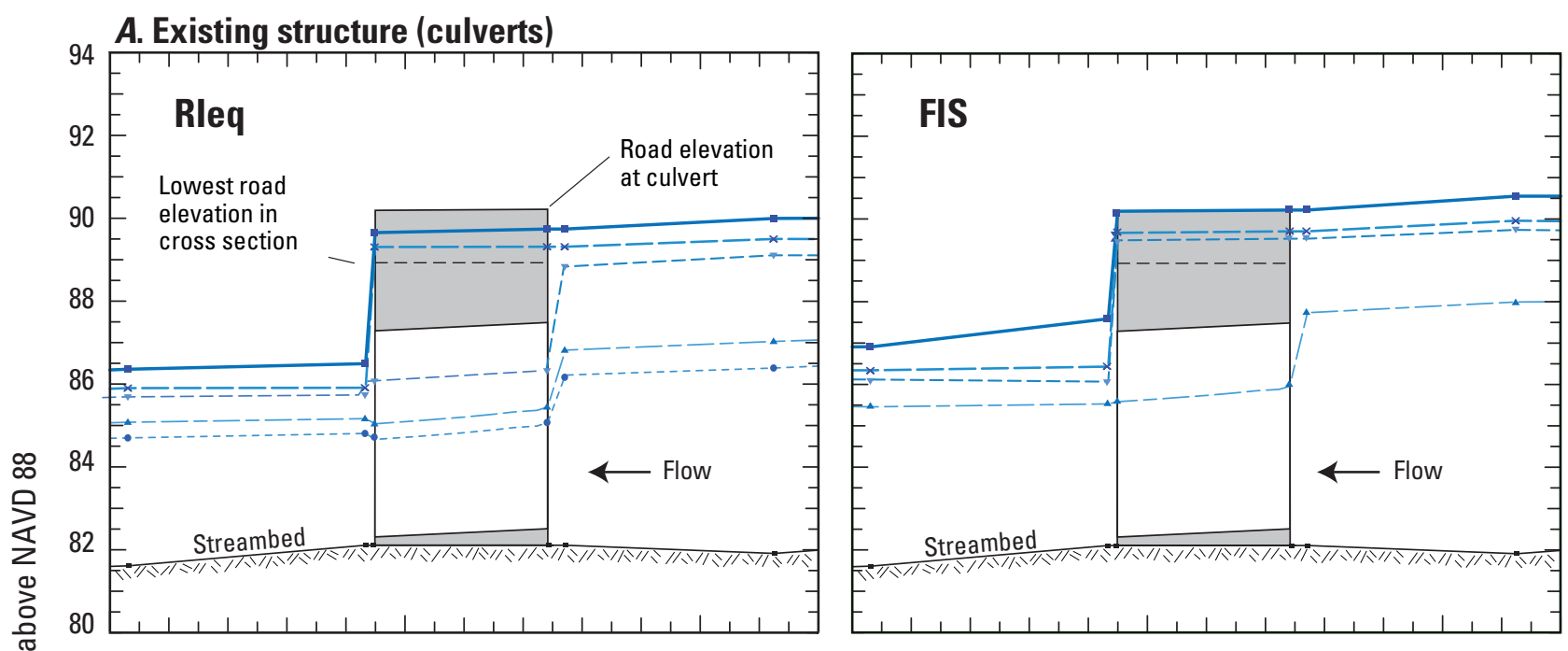

B. Alternative stream crossing providing fish and wildlife passage
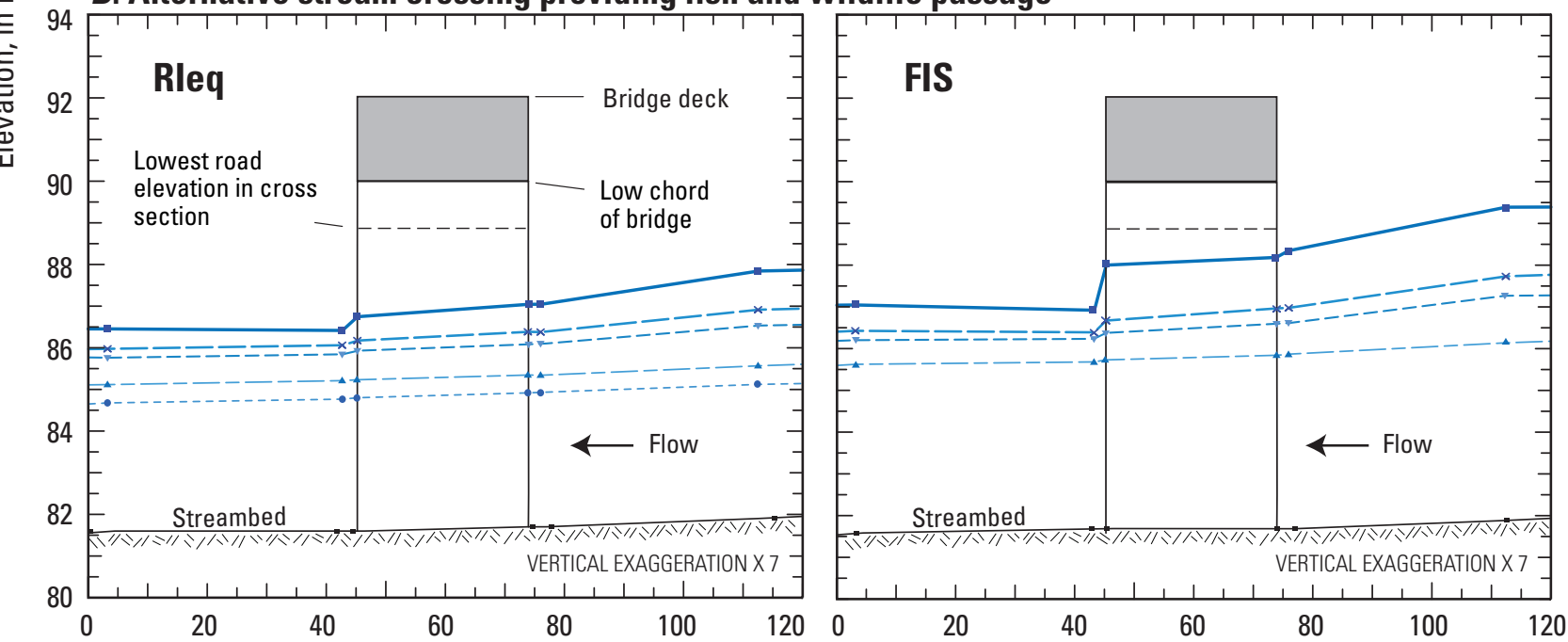

Distance, in feet

EXPLANATION

Water-surface elevations for annual exceedance probability (AEP) flood flows from (\%, percent; $\mathrm{ft}^{3} / \mathrm{s}$, cubic feet per second)

Rhode Island Regional Equations ${ }^{1}$ (Rleq)

\begin{tabular}{|c|c|c|}
\hline & AEP & Flow \\
\hline$\rightarrow$ & $0.2 \%$ & $900 \mathrm{ft}^{3} / \mathrm{s}$ \\
\hline$-*-$ & $1 \%$ & $640 \mathrm{ft}^{3} / \mathrm{s}$ \\
\hline$-\rightarrow--$ & $2 \%$ & $540 \mathrm{ft}^{3} / \mathrm{s}$ \\
\hline$-\star-$ & $10 \%$ & $320 \mathrm{ft}^{3} / \mathrm{s}$ \\
\hline & $20 \%$ & $250 \mathrm{ft}^{3} / \mathrm{s}$ \\
\hline
\end{tabular}

Flood Insurance Study² (FIS)

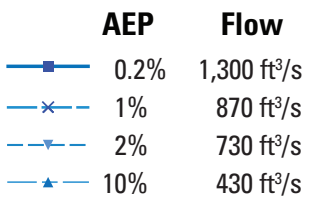

Symbols represent simulated points in model cross sections

'Regional flood-flow equations for Rhode Island and surrounding areas (Zarriello and others, 2012).

${ }^{2}$ Flood Insurance Study, Bristol County, Massachusetts (FEMA, 2012)

Figure 15. Simulated Sevenmile River water-surface elevation profiles at Read Street in Attleboro, Massachusetts: $A$, existing structure, and $B$, alternative stream crossing providing fish and wildlife passage. 
Table 8. Hydraulic characteristics of simulated stream-crossing structures at the 10- and 1-percent annual exceedance probability flow for Sevenmile River at Read Street in Attleboro, Massachusetts.

[AEP, annual exceedance probability; W.S., water surface; $\mathrm{ft}$, feet; $\mathrm{ft} / \mathrm{s}$, feet per second; $\mathrm{ft}^{3} / \mathrm{s}$, cubic feet per second; US, upstream; DS, downstream; --, not determined. Flows determined by using Rhode Island regional flood equations (Zarriello and others, 2012)]

\begin{tabular}{|c|c|c|c|c|c|}
\hline \multicolumn{2}{|c|}{ Model station } & \multicolumn{2}{|c|}{ Existing structure } & \multicolumn{2}{|c|}{ Alternative structure } \\
\hline Number & Description & $\begin{array}{l}\text { W.S. elevation } \\
\text { (ft) }\end{array}$ & $\begin{array}{c}\text { Stream velocity } \\
(\mathrm{ft} / \mathrm{s})\end{array}$ & $\begin{array}{l}\text { W.S. elevation } \\
\text { (ft) }\end{array}$ & $\begin{array}{c}\text { Stream velocity } \\
(\mathrm{ft} / \mathrm{s})\end{array}$ \\
\hline \multicolumn{6}{|c|}{10 -percent AEP $\left(320 \mathrm{ft}^{3} / \mathrm{s}\right)$} \\
\hline 17,876 & Approach & 87.02 & 2.1 & 85.48 & 3.7 \\
\hline 17,838 & US face & 86.83 & 3.7 & 85.25 & 4.7 \\
\hline \multirow[t]{2}{*}{17,822} & US culvert/bridge ${ }^{1}$ & 86.83 & 8.9 & 85.25 & 4.7 \\
\hline & DS culvert/bridge ${ }^{1}$ & -- & 10 & 85.11 & 4.9 \\
\hline 17,806 & DS face & 85.60 & 6.5 & 85.08 & 5.0 \\
\hline 17,766 & Exit & 84.97 & 4.4 & 84.97 & 4.4 \\
\hline \multicolumn{6}{|c|}{ 1-percent AEP (640 ft³ $/ \mathrm{s})$} \\
\hline 17,876 & Approach & 89.35 & 2.5 & 86.89 & 4.4 \\
\hline 17,838 & US face & 89.01 & 4.8 & 86.35 & 6.6 \\
\hline \multirow[t]{2}{*}{17,822} & US culvert/bridge $^{1}$ & 89.01 & 12 & 86.34 & 6.6 \\
\hline & DS culvert/bridge ${ }^{1}$ & -- & 13 & 86.14 & 6.9 \\
\hline 17,806 & DS face & 85.72 & 10 & 86.03 & 7.2 \\
\hline 17,766 & Exit & 85.95 & 6.0 & 85.96 & 6.0 \\
\hline
\end{tabular}

${ }^{1}$ Internal sections created by model.

to an elevation of $92 \mathrm{ft}$. The bridge has a cross-sectional area of about $247 \mathrm{ft}^{2}$, which is about 4 times the combined crosssectional area of the culverts $\left(58.9 \mathrm{ft}^{2}\right)$, and an openness ratio of about $8.5 \mathrm{ft}$, which is about 12 times the openness ratio of the existing structure.

Hydraulically, the bridge is able to convey all simulated flows without causing substantial backwater or road overflow (fig. 15B). The WSE (88.5 ft) was near the low chord of the bridge (90 ft) only for the highest simulated flow (FIS at $1,300 \mathrm{ft}^{3} / \mathrm{s}$ ) and slightly below the lowest road crossing elevation $(88.9 \mathrm{ft})$. Stream velocities at the bridge for the 10 and 1-percent AEP RIeq flows were similar to the velocities at the exit cross section.

The bridge meets or exceeds optimal AOP standards in terms of openness, opening height, and velocity. The simulated WSE profiles for the various AEP flows indicate that a similar design improves flood resiliency by meeting the conveyance requirements for updated flood flows at Read Street with some buffer to allow for uncertainties in actual flood flows or potential increases in flood flows. A similar structure would less likely be affected by debris and erosion hazards or failure from sharp increases in velocity compared to the existing structure.

\section{Segreganset River at Glebe Street in Taunton}

The Segreganset River in southeastern Massachusetts (fig. 1) is crossed by Glebe Street about 3 mi west of Taunton near the headwaters of the basin. The river has a drainage area of $0.97 \mathrm{mi}^{2}$ at Glebe Street. During the field survey at relatively low-flow conditions, the downstream end of the culvert contained water, but the upstream end was mostly dry. The existing structure has an openness ratio of $0.40 \mathrm{ft}$, which likely deters passage of most aquatic organisms and wildlife. The Glebe Street crossing appreciably constricts the natural channel, as indicated by the upstream face profile shown in figure $16 \mathrm{~A}$.

Simulations indicate that the existing structure causes backwater for all simulated flood flows but appreciably more for flows with a 2-percent AEP magnitude or greater (fig. 17A). No road overflow occurs for MAeq flows, but NERCC simulated flows indicate road flooding of about 0.4 to $1 \mathrm{ft}$ at the 1- and 0.2-percent AEPs, respectively. The culvert is at or near full capacity at flows greater than the 2-percent AEP magnitude determined with both MAeq and NERCC methods.

The channel constriction from the existing structure is evident by the sharp increase in stream velocity through the culvert (table 9). At the 10- and 1-percent AEP MAeq 


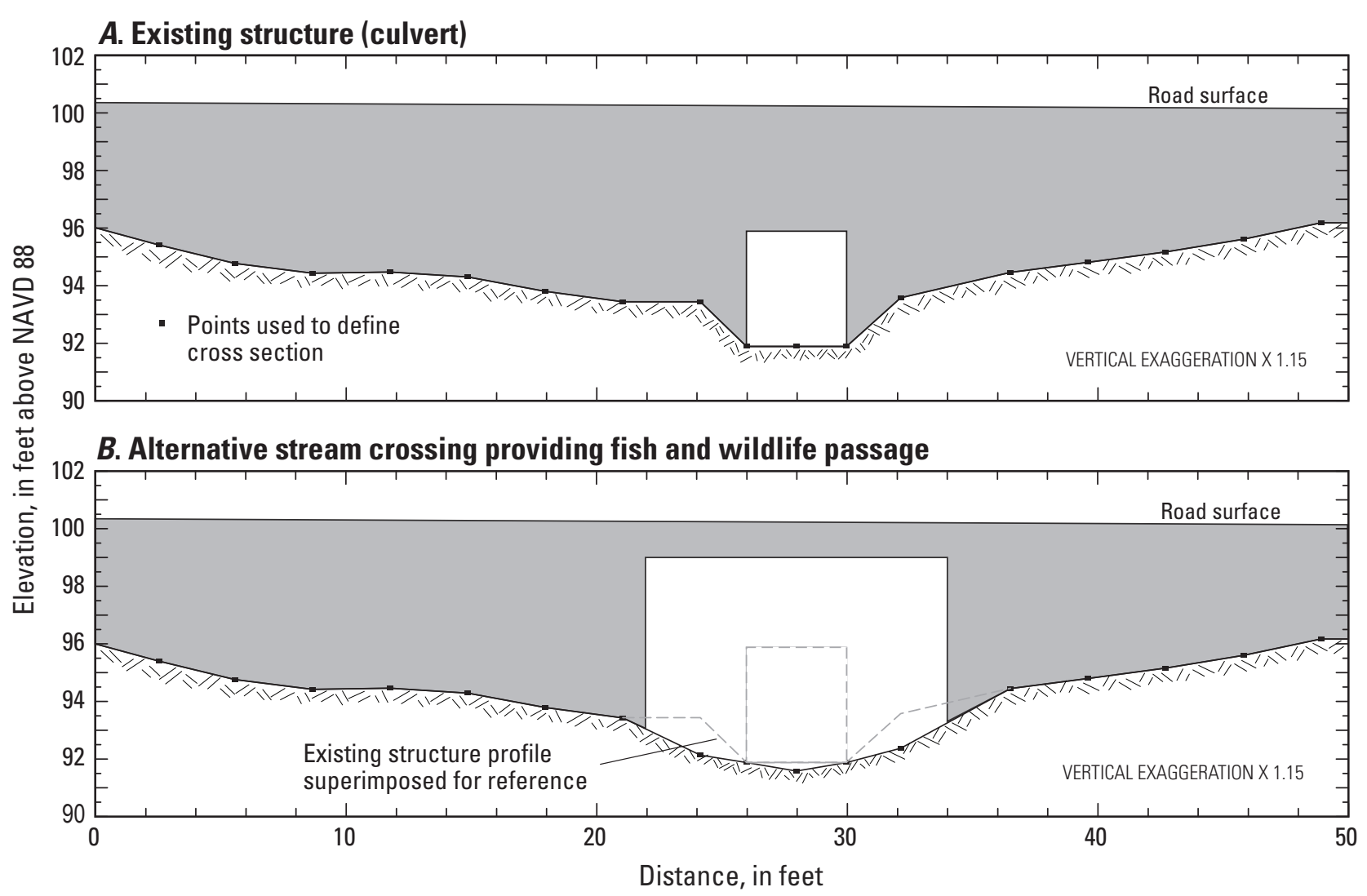

Figure 16. Upstream face cross section of Glebe Street at Segreganset River in Attleboro, Massachusetts: $A$, existing structure, and $B$, alternative stream crossing providing fish and wildlife passage.

flows, stream velocities through the culvert were about 2 to 3 times the stream velocities at the exit cross sections. The simulations indicate that velocities likely increase markedly under more moderate flows and are an impediment to aquatic organism passage.

A hypothetical bridge that incorporates AOP standards was simulated to replace the existing culvert at Glebe Street (fig. 16B). The bridge span was determined from the bankfull width determined from 3 upstream and 4 downstream model cross sections that varied from 10 to $16 \mathrm{ft}$. The average bankfull width $(12.1 \mathrm{ft})$ was about equal to the width $(12 \mathrm{ft})$ determined by the two-parameter regional bankfull equations of Bent and Waite (2013). The rounded bankfull width multiplied by 1.2 resulted in a span of $14 \mathrm{ft}$, which is similar to the width of the channel cross section at the upstream face of the existing culvert (fig. 16B). The channel bottom was lowered slightly to maintain a smooth streambed gradient creating a height to the low chord of the bridge of about $7 \mathrm{ft}$ at the thalweg and $6 \mathrm{ft}$ at the abutments. Although a slightly higher opening would be optimal, the structure was designed to maintain the existing road elevation. The opening of the bridge has a cross-sectional area of $83 \mathrm{ft}^{2}$, which is 5 times larger than that of the existing culvert $\left(16 \mathrm{ft}^{2}\right)$. The bridge has an openness ratio of about $2.1 \mathrm{ft}$, which is 5 times larger than the ratio of the existing culvert.

Hydraulically, the bridge is able to convey all simulated flows without causing substantial backwater (fig. 17B), except for the 0.2-percent AEP NERCC flow. At this flow, the simulated WSE at the upstream face of the bridge $(100 \mathrm{ft})$ was $1 \mathrm{ft}$ above the low chord of the bridge and slightly below the lowest road elevation $(100.1 \mathrm{ft})$. Stream velocities at the bridge at the 10- and 1-percent AEP MAeq flows were about 33 percent greater than velocity at the exit cross section.

The bridge meets or exceeds AOP standards in terms of openness, opening height, and velocity, although some standards are less than optimal to minimize changes to the elevation of the road crossing. Still, the simulated WSE profiles for the various AEP flows indicate that a similar design would improve flood resiliency by meeting the conveyance requirements for flood flows with some buffer to allow for uncertainties in actual flood flows or potential increases in floods flows. A similar structure would less likely be affected by debris and erosion hazards or failure from increased stream velocity than the existing structure. 

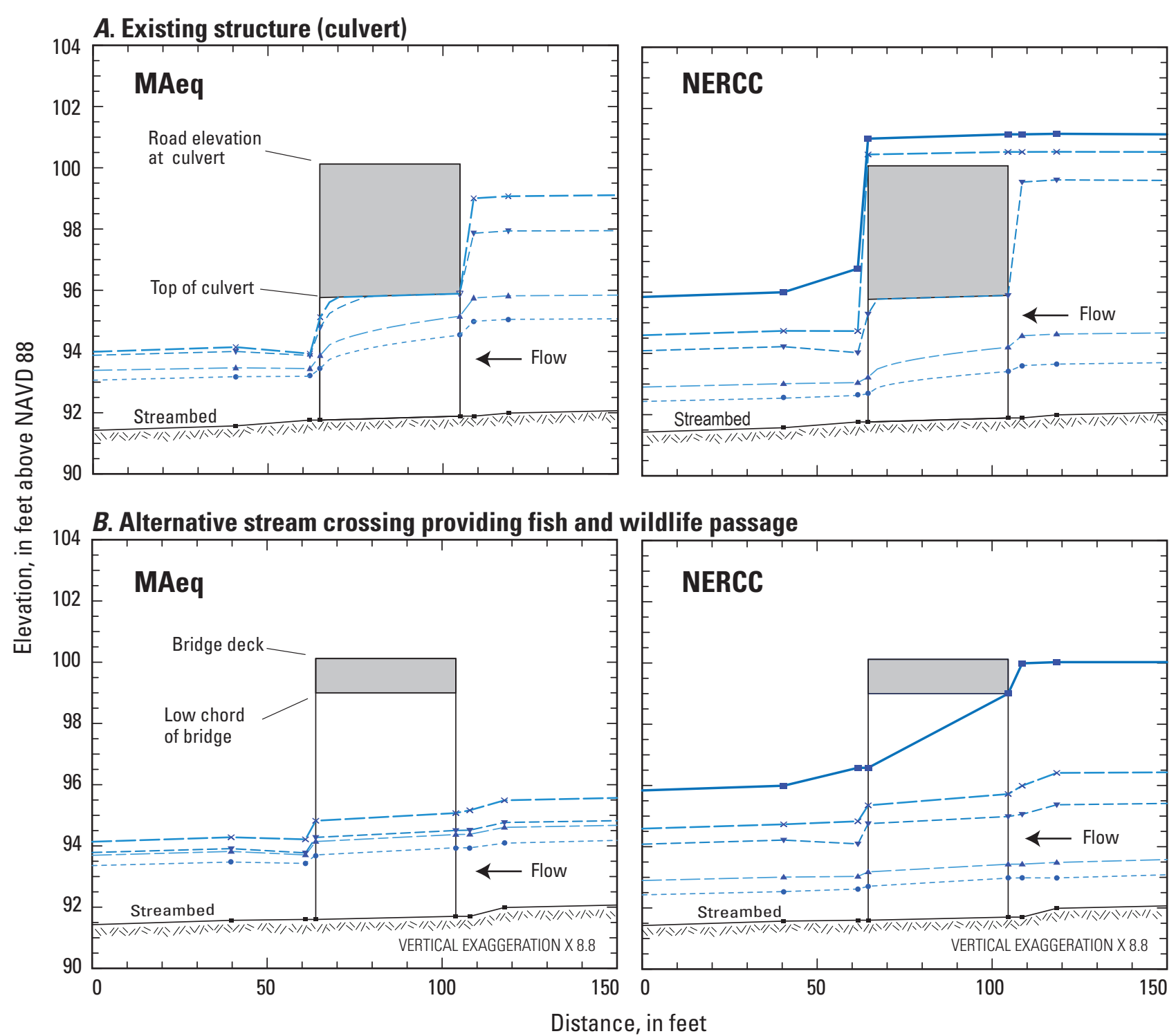

EXPLANATION

Water-surface elevations for annual exceedance probability (AEP) flood flows from $\left(\%\right.$, percent; $\mathrm{ft}^{3} / \mathbf{s}$, cubic feet per second)

Massachusetts regional equations ${ }^{1}$ (MAeq)

$$
\begin{aligned}
& \text { AEP Flow } \\
& \text { - }-1 \% \quad 140 \mathrm{ft}^{3} / \mathrm{s} \\
& -\rightarrow-2 \% \quad 120 \mathrm{ft}^{3} / \mathrm{s} \\
& \quad-10 \% \quad 70 \mathrm{ft}^{3} / \mathrm{s} \\
& \quad 50 \mathrm{ft}^{3} / \mathrm{s}
\end{aligned}
$$

\begin{tabular}{|c|c|c|}
\hline & AEP & Flow \\
\hline 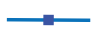 & $0.2 \%$ & $570 \mathrm{ft}^{3} / \mathrm{s}$ \\
\hline$-*-$ & $1 \%$ & $240 \mathrm{ft}^{3} / \mathrm{s}$ \\
\hline$--\pi-$ & $2 \%$ & $150 \mathrm{ft}^{3} / \mathrm{s}$ \\
\hline$-\leftarrow-$ & $10 \%$ & $40 \mathrm{ft}^{3} / \mathrm{s}$ \\
\hline$--\infty$ & $20 \%$ & $20 \mathrm{ft}^{3} / \mathrm{s}$ \\
\hline
\end{tabular}

Symbols represent simulated points in model cross sections
TR-55 NERCC² (NERCC)

${ }^{1}$ Regional regression equations for estimating flood flows in Massachusetts (Wandle, 1983).

${ }^{2}$ Rainfall-runoff model TR-55 and Northeast Regional Climate Center (NERCC) extreme precipitation (DeGaetano and Zarrow, undated).

Figure 17. Simulated Segreganset River water-surface elevation profiles at Glebe Street in Taunton, Massachusetts: $A$, existing structure, and $B$, alternative stream crossing providing fish and wildlife passage. 
Table 9. Hydraulic characteristics of simulated structures at the 10- and 1-percent annual exceedance probability flow for Segreganset River at Glebe Street in Taunton, Massachusetts.

[AEP, annual exceedance probability; W.S., water surface; $\mathrm{ft}$, feet; ft/s, feet per second; $\mathrm{ft}^{3} / \mathrm{s}$, cubic feet per second; US, upstream; DS, downstream; --, not determined. Flows determined with Massachusetts regional flood-flow equations (Wandle, 1983)]

\begin{tabular}{|c|c|c|c|c|c|}
\hline \multicolumn{2}{|c|}{ Model station } & \multicolumn{2}{|c|}{ Existing structure } & \multicolumn{2}{|c|}{ Alternative structure } \\
\hline Number & Description & $\begin{array}{c}\text { W.S. elevation } \\
\text { (ft) }\end{array}$ & $\begin{array}{c}\text { Stream velocity } \\
(\mathrm{ft} / \mathrm{s})\end{array}$ & $\begin{array}{c}\text { W.S. elevation } \\
\text { (ft) }\end{array}$ & $\begin{array}{c}\text { Stream velocity } \\
(\mathrm{ft} / \mathrm{s})\end{array}$ \\
\hline \multicolumn{6}{|c|}{ 10-percent AEP $\left(70 \mathrm{ft}^{3} / \mathrm{s}\right)$} \\
\hline 1,193 & Approach & 95.82 & 1.0 & 94.10 & 3.2 \\
\hline 1,183 & US face & 95.75 & 2.3 & 93.94 & 4.0 \\
\hline \multirow[t]{2}{*}{1,157} & US culvert/bridge ${ }^{1}$ & 95.75 & 5.4 & 93.94 & 3.8 \\
\hline & DS culvert/bridge ${ }^{1}$ & -- & 8.3 & 93.71 & 4.3 \\
\hline 1,136 & DS face & 93.45 & 5.2 & 93.43 & 5.6 \\
\hline 1,115 & Exit & 93.48 & 3.0 & 93.48 & 3.0 \\
\hline \multicolumn{6}{|c|}{ 1-percent AEP $\left(140 \mathrm{ft}^{3} / \mathrm{s}\right)$} \\
\hline 1,193 & Approach & 99.06 & 0.9 & 95.20 & 3.0 \\
\hline 1,183 & US face & 99.00 & 2.2 & 94.93 & 4.9 \\
\hline \multirow[t]{2}{*}{1,157} & US culvert/bridge ${ }^{1}$ & 99.00 & 8.8 & 94.88 & 5.0 \\
\hline & DS culvert/bridge ${ }^{1}$ & -- & 10 & 94.65 & 5.4 \\
\hline 1,136 & DS face & 93.93 & 7.7 & 94.00 & 7.8 \\
\hline 1,115 & Exit & 94.15 & 3.9 & 94.15 & 3.9 \\
\hline
\end{tabular}

${ }^{1}$ Internal sections created by model.

\section{Churchill Brook at Churchill Street and at Hancock Road in Pittsfield}

Churchill Brook stream crossings at Churchill Street and Hancock Road, about 3 mi northwest of the center of Pittsfield in western Massachusetts (fig. 1), are scheduled for replacement. Unlike the other sites in this study, replacement structures have been designed to meet AOP standards by an independent engineering contractor (Foresight Land Services) hired by the Housatonic Valley Association (Dennis Regan, Housatonic Valley Association, written commun., 2013).

Churchill Street and Hancock Road cross the brook at about 0.3 and $0.4 \mathrm{mi}$, respectively, from its mouth at Onota Lake. The brook has a drainage area of $1.13 \mathrm{mi}^{2}$ at Hancock Road and $1.18 \mathrm{mi}^{2}$ at Churchill Street. The downstream ends of the culverts are elevated relative to the water surface at low to moderate flows (figs. 7A and B) and together with the small openness ratios of the Churchill Street and Hancock Road structures ( 0.18 and $0.16 \mathrm{ft}$, respectively) create a substantial deterrent for the passage of most aquatic organisms and wildlife. The constrictions on Churchill Brook at Churchill Street and Hancock Road crossings are apparent in the upstream profiles shown in figures 18A and 19A, respectively.

Simulations indicate that the existing culvert at Churchill Street causes backwater for all simulated flood flows except the 20-percent AEP NERCC flow (fig. 20A). Road overflow occurs at and above the 2-percent AEP flows determined by the EMA and NERCC methods. The depth of road overflow ranges from about 1 to $2.5 \mathrm{ft}$ at the 2- to 0.2-percent AEPs, but the overflow depth for a given AEP is appreciably different (higher) only at the 0.2-percent AEP NERCC flow compared to the EMA flow (fig. 20A). The culvert is at or near full capacity for all simulated flows except the 20-percent AEP NERCC flow.

The channel constriction at Churchill Street from the existing structure is also evident by the sharp increase in stream velocity through the culvert (table 10). At the 10- and 1-percent AEP EMA flows, stream velocities through the culvert are about 3 times the exit cross-section velocity. The approach cross-section velocity is substantially lower than the culvert and exit velocities, which reflects backwater caused by the severely contracted opening. Although these velocities are for flood flows that occur infrequently, the simulations indicate that velocities likely increase markedly under more moderate flows and impede aquatic organism passage.

Structures that incorporate AOP standards at Churchill Street and Hancock Road, developed by Foresight Land Services, are three-sided cement box culverts that are open at the bottom; they were simulated as bridges (figs. 18B and 19B, respectively). Both replacement structures are $18 \mathrm{ft}$ 


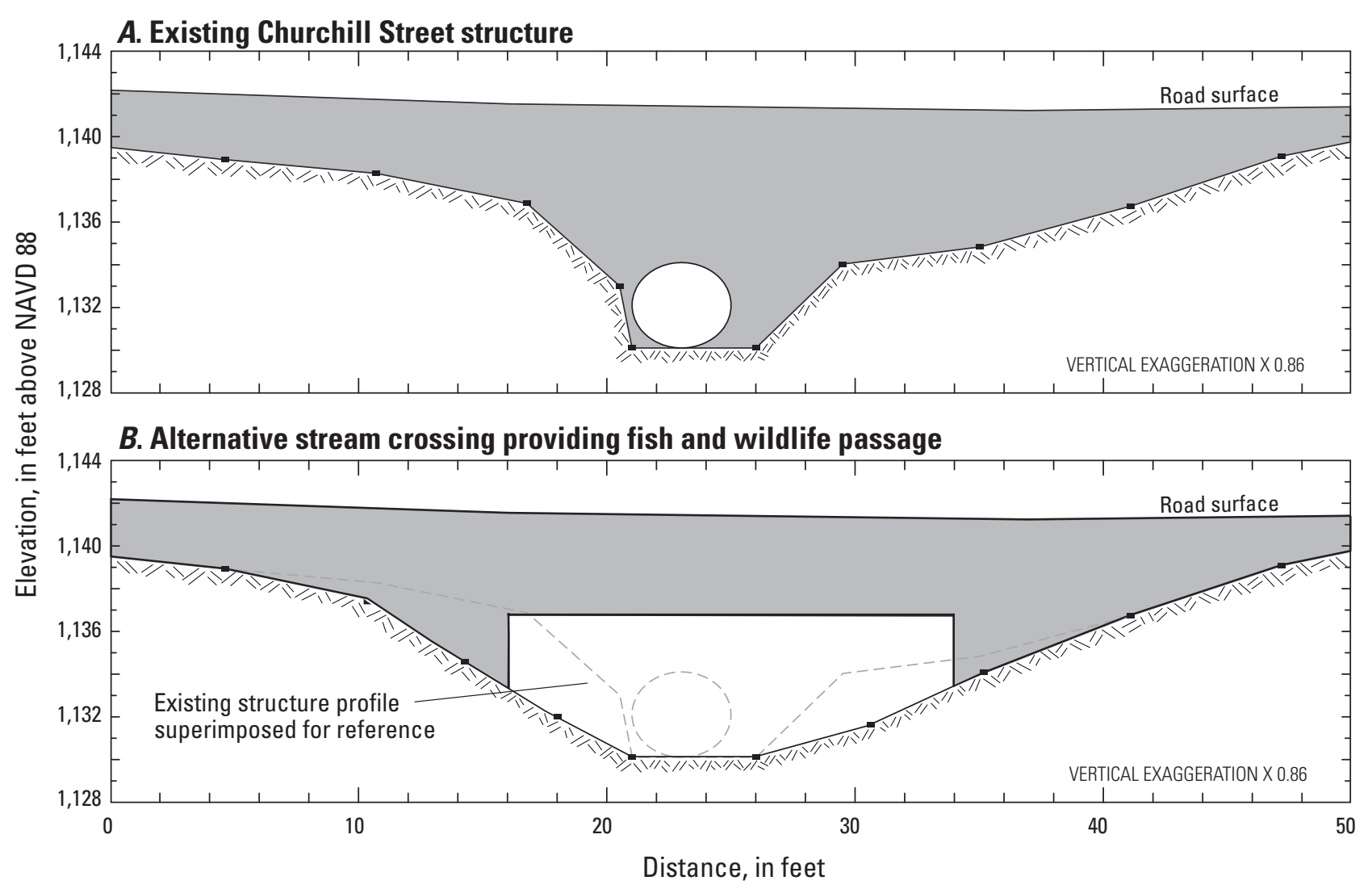

Figure 18. Upstream face cross section of Churchill Brook at Churchill Street in Pittsfield, Massachusetts: $A$, existing structure, and $B$, alternative stream crossing providing fish and wildlife passage.

wide and about $32 \mathrm{ft}$ long. The maximum height between the streambed and low chord of the box varies depending on the existing road elevation relative to the streambed; the height between the low chord of the bridge and the streambed is about $7 \mathrm{ft}$ at Churchill Street and about $4 \mathrm{ft}$ at Hancock Road. The span width $(18 \mathrm{ft})$ is consistent with the average bankfull width multiplied by 1.2 measured at five surveyed cross sections excluding the approach, face, and exit cross sections at the two road crossings and about equal to the bankfull width determined by the single-parameter regional bankfull equations (Bent and Waite, 2013) multiplied by 1.2 (19 ft). The design for the new structure at Hancock Road includes raising the existing road elevation by about $2 \mathrm{ft}$ (fig. 19). The simulated new road slopes to the east and has an elevation of $1,115.75 \mathrm{ft}$ at the centerline of the new opening.

The Churchill Street bridge opening has a cross sectional area of about $109 \mathrm{ft}^{2}$, which is nearly 13 times larger than that of the existing culvert (about $8.6 \mathrm{ft}^{2}$ ) and an openness ratio of about $3.4 \mathrm{ft}$, which is about 12 times larger than the existing culvert. The Hancock Road bridge has a cross sectional area of about $55 \mathrm{ft}^{2}$, which is nearly 6 times larger than that of the combined area of the two existing culverts (about $9.8 \mathrm{ft}^{2}$ ), and an openness ratio of about $1.7 \mathrm{ft}$, which is about 11 times larger than a single culvert.

Hydraulically, the Churchill Street bridge is able to convey all simulated flows without causing substantial backwater (fig. 20B), except at the highest simulated flow (NERCC 0.2-percent AEP). At the 0.2-percent AEP NERCC flow, the water surface at the upstream face is about $1.3 \mathrm{ft}$ above the low chord of the bridge. Stream velocities through the bridge (table 10) at the 10- and 1-percent AEP EMA flows are similar to the velocities at the approach and exit cross sections, indicating that under more moderate flows the velocity at the bridge likely is not an impediment to aquatic organism passage.

HEC-RAS simulations of the Hancock Road structure are complicated by the low road elevation to the east of the structure, as previously described. The same multiple openings and obstructions used to restrict flow over the low road elevation to the east of the existing stream crossing were used to simulate the AOP structure, thereby allowing a comparative analysis of the existing and alternative structures. Simulations indicate that the redesigned Hancock Road structure can convey the 2-percent AEP simulated flows without causing 


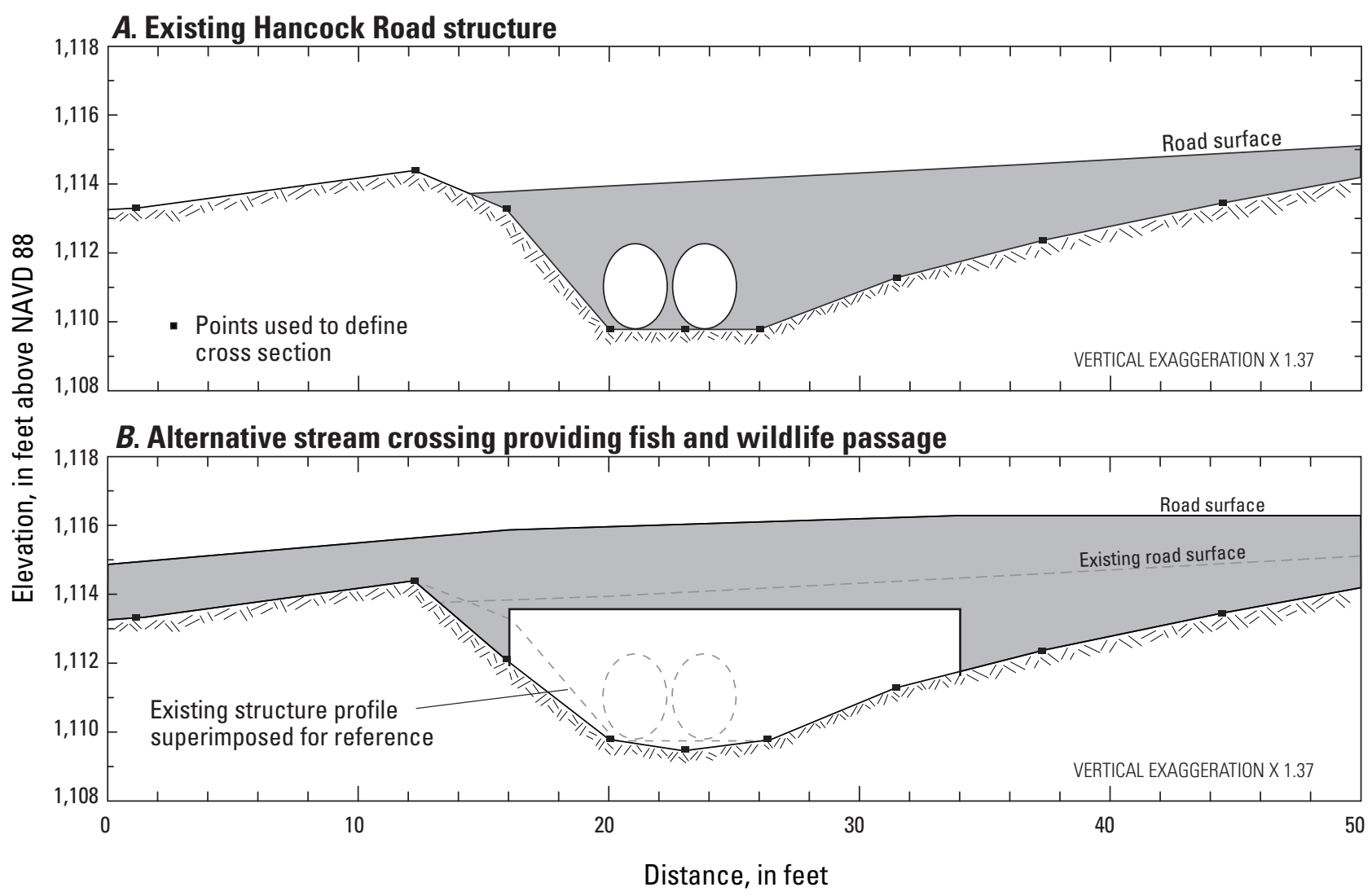

Figure 19. Upstream face cross section of Churchill Brook at Hancock Road in Pittsfield, Massachusetts: $A$, existing structure, and $B$, alternative stream crossing providing fish and wildlife passage.

backwater and cause only a small amount of backwater at the 1-percent AEP flows (fig. 21B) with a minor amount (5 percent or less) of flow over the low road elevation east of the bridge. Backwater and road overflow at the 0.2-percent AEP flows persist for the AOP structure but to a lesser extent compared to that for the existing culverts. At the 0.2-percent AEP EMA flow, road overflow at the opening representing the bridge section accounts for less than 1 percent of the total flow with minor flooding over the road on the east side of the opening. Note that, at the 0.2-percent AEP EMA flow, the water surface is below the road elevation at the center of the bridge as shown in figure $21 \mathrm{~B}$, but the road surface slopes and the figure does not show the lowest road elevation within the cross section representing the bridge opening. The opening representing the low road elevation to the east accounts for about 21 percent of the total EMA flow; the depth over the low elevation is about $1.6 \mathrm{ft}$. At the 0.2-percent AEP NERCC flow, road overflow at the opening representing the bridge section accounts for about 12 percent of the total flow. The maximum depth of water over the road is about $1.2 \mathrm{ft}$, and the depth decreases as the road elevation rises to the west. The opening representing the low road elevation to the east accounts for about 36 percent of the total NERCC flow; the depth over the low elevation is about $2.3 \mathrm{ft}$.

Stream velocities through the bridge (table 10) at the 10 and 1-percent AEP EMA flows are similar to the velocities at the approach and exit cross sections, indicating that under more moderate flows the velocity at the bridge would not be an impediment to aquatic organism passage. Note that the simulated water-surface profile and stream velocities at the Hancock Road crossing may change appreciably, depending on the amount of flow allowed to pass through the multiple openings representing the low road elevation to the east of the stream crossing.

The Churchill Street and Hancock Road bridges meet or exceed general AOP standards in terms of openness and velocity, although the height standard is less than optimal at Hancock Road in order to minimize changes to the elevation of the road crossing. Still, the simulated WSE profiles for the various AEP flows indicate that the AOP structures improve flood resiliency by meeting the conveyance requirements for AEP flood flows. The alternative structures are less likely to be affected by debris and erosion hazards from increased stream velocity compared to the existing structures. 

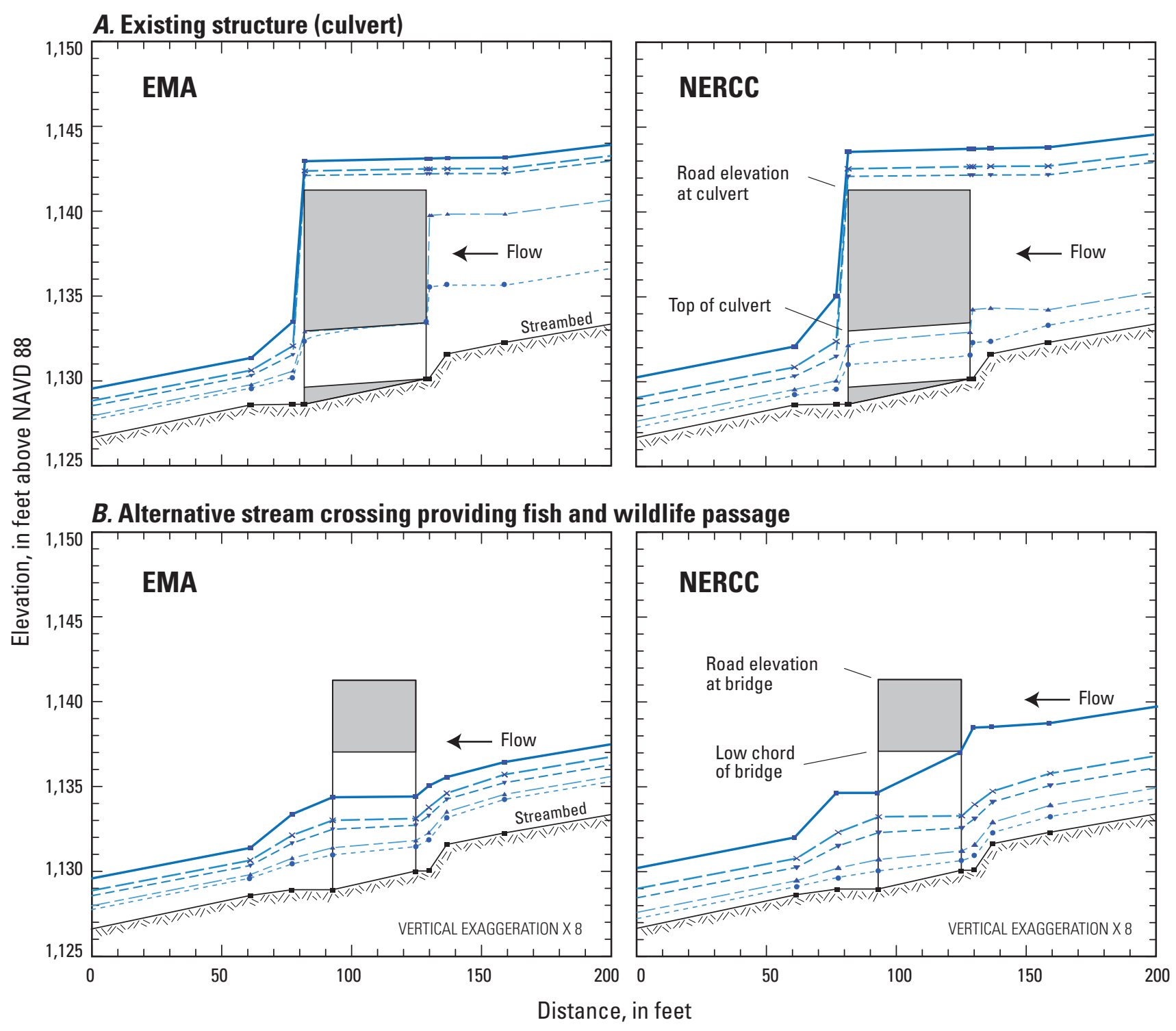

\section{EXPLANATION}

Water-surface elevations for annual exceedance probability (AEP) flood flows from $\left(\%\right.$, percent; $\mathrm{ft}^{3} / \mathrm{s}$, cubic feet per second)

EMA extended record' (EMA)

\begin{tabular}{|c|c|}
\hline & AEP \\
\hline$\longrightarrow$ & $0.2 \%$ \\
\hline$-*-$ & $1 \%$ \\
\hline$--k-$ & $2 \%$ \\
\hline$-\div-$ & $10 \%$ \\
\hline$\ldots$ & $20 \%$ \\
\hline
\end{tabular}

TR-55 NERCC ${ }^{2}$ (NERCC)

$\begin{array}{ccc}\text { AEP } & \text { Flow } \\ - & 0.2 \% & 910 \mathrm{ft}^{3} / \mathrm{s} \\ -*- & 1 \% & 370 \mathrm{ft}^{3} / \mathrm{s} \\ --- & 2 \% & 230 \mathrm{ft}^{3} / \mathrm{s} \\ ---10 \% & 60 \mathrm{ft}^{3} / \mathrm{s} \\ ---20 \% & 20 \mathrm{ft}^{3} / \mathrm{s}\end{array}$

Symbols represent simulated points in model cross sections

1 Expected moments analysis (EMA) of annual peak flows at Churchill Brook 01197050 with extended record.

${ }^{2}$ Rainfall-runoff model TR-55 and Northeast Regional Climate Center (NERCC) extreme precipitation (DeGaetano and Zarrow, undated).

Figure 20. Simulated Churchill Brook water-surface elevation profiles at Churchill Street in Pittsfield, Massachusetts: $A$, existing structure, and $B$, alternative stream crossing providing fish and wildlife passage. 
Table 10. Hydraulic characteristics of simulated stream-crossing structures at the 10- and 1-percent annual exceedance probability flow for Churchill Brook in Pittsfield, Massachusetts.

[AEP, annual exceedance probability; W.S., water surface; $\mathrm{ft}$, feet; $\mathrm{ft} / \mathrm{s}$, feet per second; $\mathrm{ft}^{3} / \mathrm{s}$, cubic feet per second; US, upstream; DS, downstream; --, not determined. Flows determined by expected moments analysis of annual peaks at Churchill Brook (01197050) with extended record using Green River at Williamstown (01333000)]

\begin{tabular}{|c|c|c|c|c|c|}
\hline \multicolumn{2}{|c|}{ Model station } & \multicolumn{2}{|c|}{ Existing structure } & \multicolumn{2}{|c|}{ Alternative structure } \\
\hline Number & Description & $\begin{array}{l}\text { W.S. elevation } \\
\text { (ft) }\end{array}$ & $\begin{array}{c}\text { Stream velocity } \\
(\mathrm{ft} / \mathrm{s})\end{array}$ & $\begin{array}{l}\text { W.S. elevation } \\
\text { (ft) }\end{array}$ & $\begin{array}{c}\text { Stream velocity } \\
(\mathrm{ft} / \mathrm{s})\end{array}$ \\
\hline \multicolumn{6}{|c|}{ Churchill Street } \\
\hline \multicolumn{6}{|c|}{ 10-percent AEP $\left(120 \mathrm{ft}^{3} / \mathrm{s}\right)$} \\
\hline & Approach & $1,139.82$ & 0.7 & $1,133.48$ & 6.2 \\
\hline & US face & $1,139.74$ & 2.2 & $1,132.25$ & 4.9 \\
\hline & US culvert/bridge $^{1}$ & $1,139.74$ & 14 & $1,131.79$ & 6.6 \\
\hline & DS culvert/bridge ${ }^{1}$ & -- & 14 & $1,131.37$ & 4.6 \\
\hline & DS face & $1,130.58$ & 7.1 & $1,130.75$ & 6.7 \\
\hline & Exit & $1,129.79$ & 5.2 & $1,129.79$ & 5.2 \\
\hline \multicolumn{6}{|c|}{ 1-percent AEP (330 fts $/ \mathrm{s})$} \\
\hline & Approach & $1,142.50$ & 1.4 & $1,134.58$ & 8.3 \\
\hline & US face & $1,142.48$ & 2.0 & $1,133.75$ & 6.8 \\
\hline & US culvert/bridge $^{1}$ & $1,142.48$ & 17 & $1,133.08$ & 8.7 \\
\hline & DS culvert/bridge ${ }^{1}$ & -- & 17 & $1,132.98$ & 6.8 \\
\hline & DS face & $1,132.07$ & 10 & $1,132.10$ & 9.1 \\
\hline & Exit & $1,130.63$ & 6.8 & $1,130.63$ & 6.8 \\
\hline \multicolumn{6}{|c|}{ Hancock Road } \\
\hline \multicolumn{6}{|c|}{ 10-percent AEP $\left(120 \mathrm{ft}^{3} / \mathrm{s}\right)$} \\
\hline & Approach & $1,114.46$ & 2.0 & $1,112.96$ & 5.8 \\
\hline & US face & $1,114.47$ & 1.5 & $1,111.61$ & 5.8 \\
\hline & US culvert/bridge $^{1}$ & $1,114.47$ & 9.9 & $1,111.46$ & 6.4 \\
\hline & DS culvert/bridge ${ }^{1}$ & -- & 13 & $1,110.62$ & 5.7 \\
\hline & DS face & $1,110.26$ & 4.4 & $1,110.45$ & 6.5 \\
\hline & Exit & $1,109.87$ & 6.1 & $1,109.87$ & 6.1 \\
\hline \multicolumn{6}{|c|}{ 1-percent AEP $\left(330 \mathrm{ft}^{3} / \mathrm{s}\right)$} \\
\hline & Approach & $1,115.26$ & 3.6 & $1,114.19$ & 6.4 \\
\hline & US face & $1,115.26$ & 3.0 & $1,114.16$ & 5.4 \\
\hline & US culvert/bridge $^{1}$ & $1,115.26$ & 12 & $1,113.50$ & 6.5 \\
\hline & DS culvert/bridge ${ }^{1}$ & -- & 12 & $1,111.99$ & 7.6 \\
\hline & DS face & $1,110.79$ & 10 & $1,111.72$ & 8.7 \\
\hline & Exit & $1,111.02$ & 8.1 & $1,111.02$ & 8.1 \\
\hline
\end{tabular}

${ }^{1}$ Internal sections created by model. 

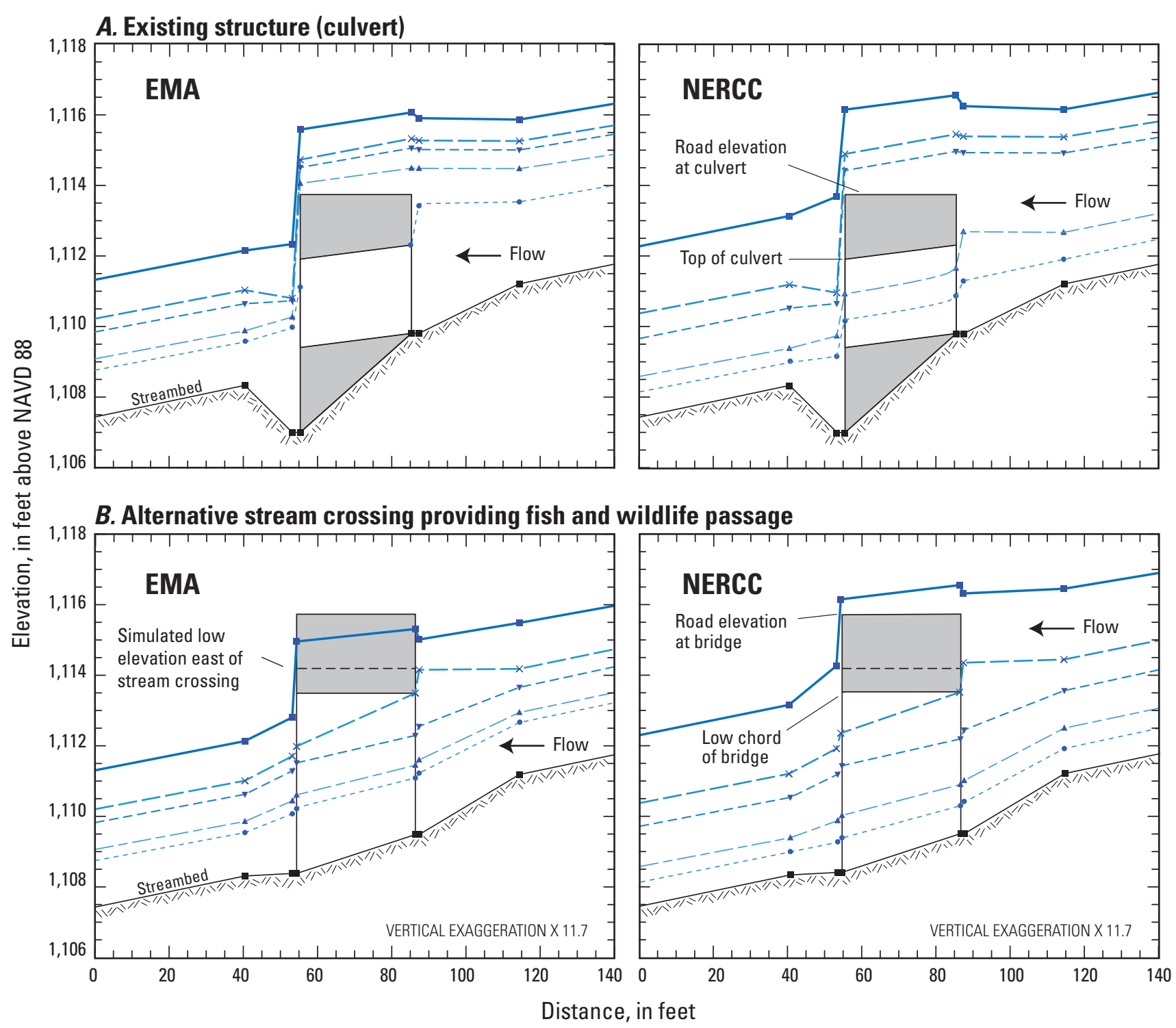

EXPLANATION

Water-surface elevations for annual exceedance probability (AEP) flood flows from $\left(\%\right.$, percent; $\mathrm{ft}^{3} / \mathrm{s}$, cubic feet per second)

EMA extended record' (EMA)

\begin{tabular}{|c|c|c|}
\hline & AEP & Flow \\
\hline$\rightarrow$ & $0.2 \%$ & $590 \mathrm{ft}^{3} / \mathrm{s}$ \\
\hline - * & $1 \%$ & $330 \mathrm{ft}^{3} / \mathrm{s}$ \\
\hline$--k-$ & $2 \%$ & $250 \mathrm{ft}^{3} / \mathrm{s}$ \\
\hline$-\star-$ & $10 \%$ & $120 \mathrm{ft}^{3} / \mathrm{s}$ \\
\hline 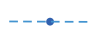 & $20 \%$ & $80 \mathrm{ft}^{3} / \mathrm{s}$ \\
\hline
\end{tabular}

TR-55 NERCC² (NERCC)

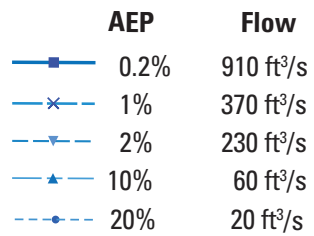

Symbols represent simulated points in model cross sections

1 Expected moments analysis (EMA) of annual peak flows at Churchill Brook 01197050 with extended record.

${ }^{2}$ Rainfall-runoff model TR-55 and Northeast Regional Climate Center (NERCC) extreme precipitation (DeGaetano and Zarrow, undated).

Figure 21. Simulated Churchill Brook water-surface elevation profiles at Hancock Road in Pittsfield, Massachusetts: $A$, existing structure, and $B$, alternative stream crossing providing fish and wildlife passage. 


\section{Summary and Conclusions}

Many stream crossings in Massachusetts are undersized for fish and wildlife passage, especially those at streams with small drainage areas that are built to accommodate a smaller range of flows. To minimize barriers to fish and wildlife passage at stream crossings, the Massachusetts River Continuity Partnership, a collaborative effort of the Massachusetts Department of Fish and Game, University of Massachusetts at Amherst, and others, have developed stream-crossing standards referred to as Aquatic Organism Passage (AOP) standards. The effects of these standards on the hydraulics of streams at crossings were evaluated by examining seven existing and alternative structures simulated to meet AOP standards. The existing structures-Mill Brook in Wilmington, Nashoba Brook in Acton, Wading River in Norton, Sevenmile River in Attleboro, Segreganset River in Taunton, and two sites on Churchill Brook in Pittsfield - consist of single- or multiple-barrel culverts with drainage basins ranging from 0.97 to $21.5 \mathrm{mi}^{2}$. The existing structures are considerably undersized with respect to AOP standards for openness, height, and span. In this study conducted by the U.S. Geological Survey, in cooperation with the Massachusetts Department of Environmental Protection, hydraulic simulations were made using HEC-RAS models of the stream reaches at and near the structures for flood flows ranging from 20- to 0.2-percent annual exceedance probabilities (AEP).

As part of this study flood flows were determined for 20-, 10-, 2-, 1-, and 0.2-percent AEPs for each of the sites. The methods used to determine flood flows varied depending on the information available and methods suitable for a site, and consequently, the 20- and 0.2-percent AEP flows were not always determined for a site. Flood flows used in the hydraulic analysis included a best and upper estimate of AEP flows to capture the inherent uncertainties of the estimates. Flood flows determined from recent data and methods are considered the most reliable relative to flows determined from a smaller population of data or less robust analysis techniques, or both. In particular, rainfall-runoff model AEP flood flows generated from 24-hour rainfall are considered the least reliable as the models are not calibrated and the assumption that at AEP rainfall produces an equivalent flood flow is unknown. Flood flows at Nashoba Brook, Wading River, and Sevenmile River were determined using recent data (through 2013 water year) and methods; flood flows at Mill Brook and Segreganset River relied on outdated methods and uncalibrated rainfallrunoff models. Churchill Brook had a short-term partial record streamgage that operated from 1964 to 1974 that was used along with a record extension to improve estimates of flood flows using updated methods. In general, flood-flow estimates could vary considerably at a site, underscoring the need to update regional flood-flow equations for the State.

Simulations of existing structures indicate that the conveyances are inadequate for most AEP flows. As a result, for most AEP simulated flows through the existing streamcrossing structures, the structures were at full capacity causing appreciable backwater upstream from the structure and, in many cases, road overflow. The simulations also indicate the existing structures appreciably increase stream velocities at the structures creating another impediment to aquatic organism passage and a potential erosion hazard that could lead to structural failure. In addition, most existing structures are prone to blockage by debris that would exacerbate upstream flooding and structural failure.

Alternative structures were simulated for each site that generally meet or exceed the AOP standards in terms of openness, velocity, and height, although height was less than optimal at some sites because of site conditions. The optimal AOP height standard was relaxed, but still met or exceeded minimum height standards, at some sites to simulate less extensive changes to the road elevation that could make alternative structures prohibitively expensive in some cases. The alternative structures were simulated as bridges to replicate the streambed and streambanks through the structure. The single opening simulated in the alternative structure is relatively large compared to the single or multiple openings of the existing structure, making the alternative structure less prone to blockage by debris. The alternative structures provide for dry passage for wildlife under normal flows (non-flood conditions) and are able to convey most simulated AEP flood flows without causing appreciable backwater. At most sites, backwater occurred only at the highest simulated flows and was often compounded by a low downstream water-surface gradient that does not reflect the conveyance capacity of the structure itself. Simulated stream velocities at the bridges indicate little or no change in velocity relative to the approach and exit cross-section stream velocities at the 10-percent AEP flows. In addition to improving passage for fish and wildlife, the alternative structures are more resilient to large floods and provide a greater buffer to uncertainties and potential changes in flood flows, making these structures less likely to fail compared to the existing structures.

\section{References Cited}

Armstrong, W.H., Collins, M.J., and Snyder, N.P., 2012, Increased frequency of low-magnitude floods in New England: Journal of the American Water Resources Association, v. 48, no. 2, p. 306-320.

Bent, G.C., and Waite, A.M., 2013, Equations for estimating bankfull channel geometry and discharge for streams in Massachusetts: U.S. Geological Survey Scientific Investigations Report 2013-5155, 62 p.

Brunner, G.W., 1010a, HEC-RAS River Analysis System, user's manual (version 4.1): Davis, Calif., U.S. Army Corps of Engineers, Hydrologic Engineering Center, CPD-68, $766 \mathrm{p}$. 
Brunner, G.W., 1010b, HEC-RAS river analysis system, hydraulic reference manual (version 4.1): Davis, Calif., U.S. Army Corps of Engineers, Hydrologic Engineering Center, CPD-69, $411 \mathrm{p}$.

Cohn, T.A., Lane, W.M., and Stedinger, J.R., 2001, Confidence intervals for expected moments algorithm flood quantile estimates: Water Resources Research, v. 37, no. 6, p. $1695-1706$.

DeGaetano, A., and Zarrow, D., undated, Extreme precipitation in New York \& New England Technical Manual: Ithaca, New York, Northeast Regional Climate Center Cornell University, version 1.12, $92 \mathrm{p}$.

Douglas, E., and Fairbanks, C., 2011, Is precipitation in northern New England becoming more extreme: Journal of Hydrologic Engineering, v. 16, no. 3, p. 203-217.

Federal Emergency Management Agency (FEMA), 1987, City of Pittsfield Massachusetts, Berkshire County, January 16, 1987, Community no. 250037: Federal Emergency Management Agency, 24 p.

Federal Emergency Management Agency (FEMA), 2010, Flood Insurance Study, Middlesex County, Massachusetts, no. 25017CV001A, dated June 4, 2010: Federal Emergency Management Agency, $131 \mathrm{p}$.

Federal Emergency Management Agency (FEMA), 2011, Guidelines and specifications for flood hazard mapping partners, Appendix M: Data capture standards, March 2011: Federal Emergency Management Agency, 170 p.

Federal Emergency Management Agency (FEMA), 2012, Flood Insurance Study, Bristol County, Massachusetts (all jurisdictions), no. 25005CV001B, preliminary date December 21, 2012: Federal Emergency Management Agency, $123 \mathrm{p}$.

Hershfield, D.M., 1961, Rainfall frequency atlas of the United States for durations from 30 minutes to 24 hours and return periods from 1 to 100 years: Weather Bureau Technical Paper No. 40: Washington D.C., U.S. Weather Bureau, 65 p.

Hirsch, R.M., 1982, A comparison of four streamflow record extension techniques: Water Resource Research, v. 18, no. 4, p. 1081-1088.

Interagency Advisory Committee on Water Data (IACWD), 1981, Guidelines for determining flood flow frequency: Bulletin 17B of the Hydrology Subcommittee, revised 1982: Reston, Va., U.S. Geological Survey, Office of Water Data Coordination, $183 \mathrm{p}$.
Jackson, S., Bowden, A., Lamber, B., and Singler, A., 2011, Massachusetts river and stream crossing standards: River and Stream Continuity Partnership, 27 p.

Johnson, C.G., and Tasker, G.D., 1974, Progress report of flood magnitude and frequency of Massachusetts streams: U.S. Geological Survey Open-File Report 74-131, 36 p.

Massachusetts Department of Transportation (MassDOT), 2010, Design of bridges and culverts for wildlife passage at freshwater streams: MassDOT Highway Division, 294 p., http://www.mhd.state.ma.us/downloads/projDev/Design_ Bridges_Culverts_Wildlife_Passage_122710.pdf.

National Resources Conservation Service, 2009, Small watershed hydrology WinTR-55 user guide: U.S. Department of Agriculture, Natural Resources Conservation Service, $142 \mathrm{p}$.

Singler, A., Graber, B., and Banks, C., 2012, Massachusetts stream crossing handbook ( $2 \mathrm{~d}$ ed.): Massachusetts Executive Office of Energy and Environmental Affairs, Department of Fish and Game, Division of Ecological Restoration, $13 \mathrm{p}$.

Wandle, S.W., 1977, Estimating the magnitude and frequency of floods on natural-flow streams in Massachusetts: U.S. Geological Survey Water-Resources Investigations Report 77-39, 26 p.

Wandle, S.W., 1983, Estimating peak discharges of small, rural streams in Massachusetts: U.S. Geological Survey Water-Supply Paper 2214, 26 p.

Wilks, D.S., and Cember, R.P., 1993, Atlas of precipitation extremes for the Northeastern United States and Southeastern Canada: Ithaca, N.Y., Cornell University, Publication No. RR 93-5, 40 p.

Zarriello, P.J., Ahearn, E.A., and Levin, S.B., 2012, Magnitude of flood flows for selected annual exceedance probabilities in Rhode Island through 2010 (ver. 1.2, revised March 27, 2013): U.S. Geological Survey Scientific Investigations Report 2012-5109, 81 p., http://pubs.usgs.gov/ sir/2012/5109.

Zarriello, P.J., and Carlson, C.S., 2009, Characteristics of the April 2007 flood at 10 streamflow-gaging stations in Massachusetts: U.S. Geological Survey Scientific Investigations Report 2009-5068, 75 p. 
Prepared by the Pembroke and West Trenton Publishing Service Centers.

For more information concerning this report, contact:

Office Chief

U.S. Geological Survey

New England Water Science Center

Massachusetts-Rhode Island Office

10 Bearfoot Road

Northborough, MA 01532

dc_ma@usgs.gov

or visit our Web site at:

http://ma.water.usgs.gov 
药

害.

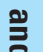

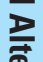

올

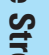

芦

옴

兽. 